Portland State University

PDXScholar

Winter 4-10-2015

\title{
Landforms along the Lower Columbia River and the Influence of Humans
}

Charles Matthew Cannon

Portland State University

Follow this and additional works at: https://pdxscholar.library.pdx.edu/open_access_etds

Part of the Geology Commons, and the Geomorphology Commons Let us know how access to this document benefits you.

\section{Recommended Citation}

Cannon, Charles Matthew, "Landforms along the Lower Columbia River and the Influence of Humans" (2015). Dissertations and Theses. Paper 2231.

https://doi.org/10.15760/etd.2228

This Thesis is brought to you for free and open access. It has been accepted for inclusion in Dissertations and Theses by an authorized administrator of PDXScholar. Please contact us if we can make this document more accessible: pdxscholar@pdx.edu. 
Landforms along the Lower Columbia River and the Influence of Humans

by

Charles Matthew Cannon

A thesis submitted in partial fulfillment of the requirements for the degree of

\author{
Master of Science \\ in \\ Geology
}

Thesis Committee:

Andrew G. Fountain, Chair Jim E. O'Connor Scott F. Burns

\title{
Portland State University 2015
}




\begin{abstract}
River systems, such as the Columbia River in the Pacific Northwest, USA have been influenced by human activities, resulting in changes to the physical processes that drive landform evolution. This work describes an inventory of landforms along the Columbia River estuary between the Pacific Ocean and Bonneville Dam in Oregon and Washington. Groupings of landforms are assigned to formative process regimes that are used to assess historical changes to floodplain features. The estuary was historically a complex system of channels with a floodplain dominated by extensive tidal wetlands in the lower reaches and backswamp lakes and wetlands in upper reaches. Natural levees flank most channels in the upper reaches, locally including areas of ridge and swale topography and crevasse splays that intrude into backswamps. Other Holocene process regimes affecting floodplain morphology have included volcanogenic deltas, tributary fans, dunes, and landslides. Pre-Holocene landforms are locally prominent and include ancient fluvial deposits and bedrock. Historical changes to streamflow regimes, floodplain isolation by flood-control systems, and direct anthropogenic disturbance have resulted in channel narrowing and limited the amount of floodplain that can be shaped by flowing water. Floodplain isolation has caused relative subsidence of tidal floodplains along much of the lower estuary. Most extant landforms are on trajectories controlled by humans and new landforms are mostly created by humans.
\end{abstract}




\section{Acknowledgements}

Charles (“Si”) Simenstad, Jennifer Burke, Mary Ramirez, and Danelle Heatwole at University of Washington School of Aquatic and Fishery Sciences; Jim O'Connor at USGS; and Keith Marcoe at Lower Columbia Estuary Partnership were collaborators on the Classification mapping. Jonathon (“Eric”) Stautberg, Jim O’Connor, Xavier Rodriguez Lloveras, and Joseph (“JoJo”) Mangano assisted with fieldwork. Lighthawk Aviation volunteer pilots Jim Richards and Jane Rosevelt provided flights over the estuary for oblique aerial photography. Reviews by Paul Pedone, John Christy, and Mackenzie Keith improved the Classification mapping on which this thesis is based. 


\section{Table of Contents}

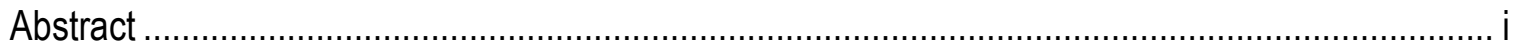

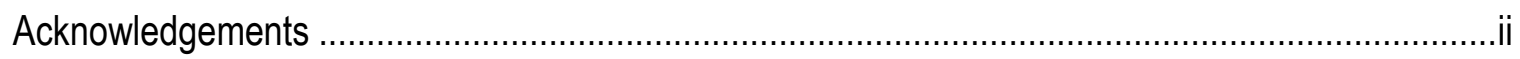

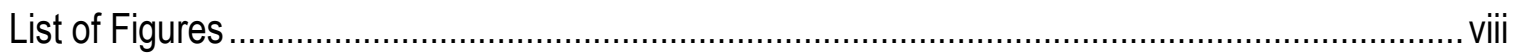

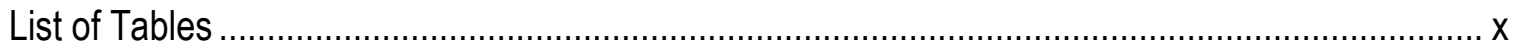

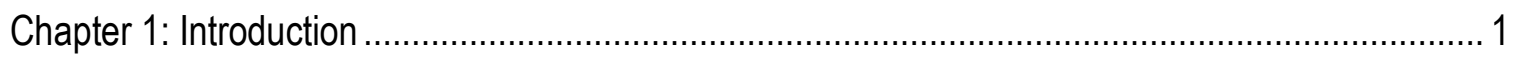

Columbia River Estuary Ecosystem Classification .......................................................... 1

Setting of the Columbia River Basin and Estuary ......................................................... 3

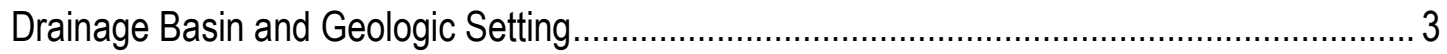

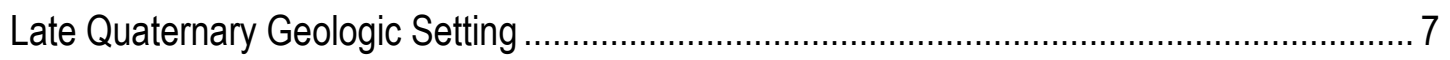

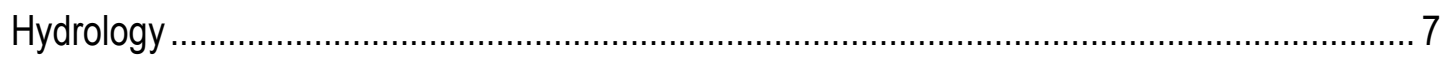

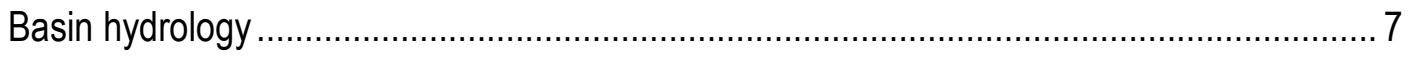

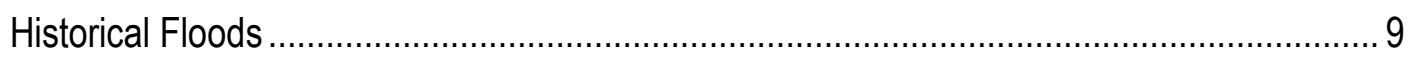

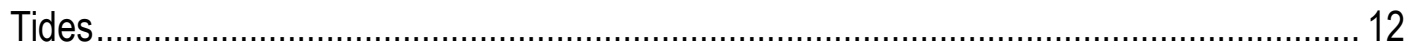

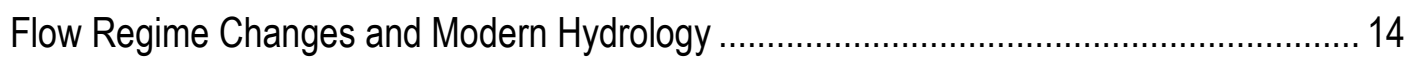

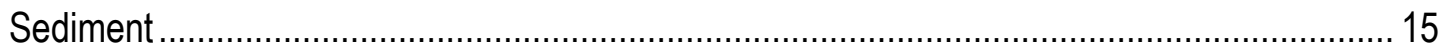

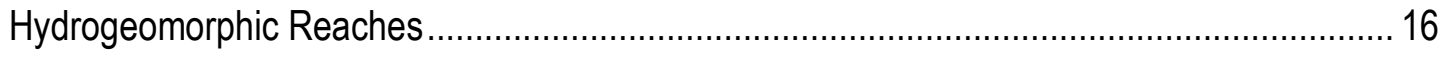

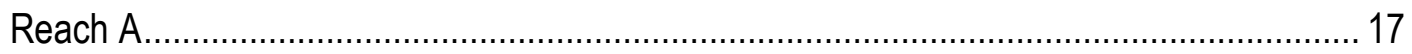

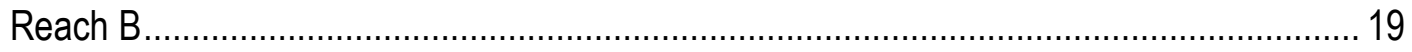

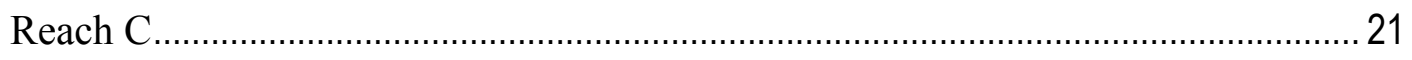

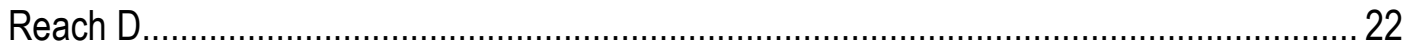

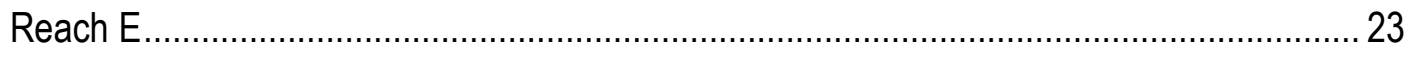

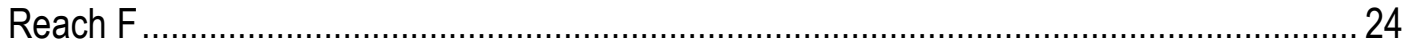




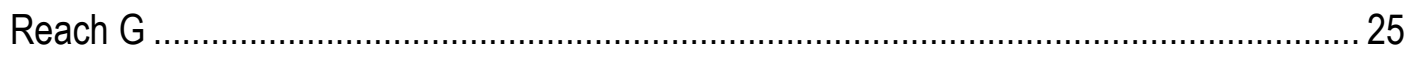

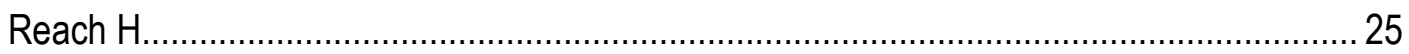

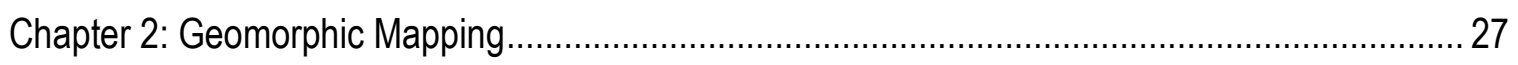

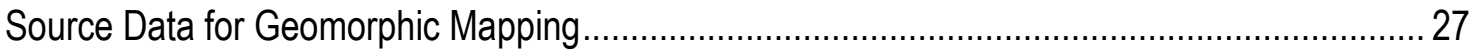

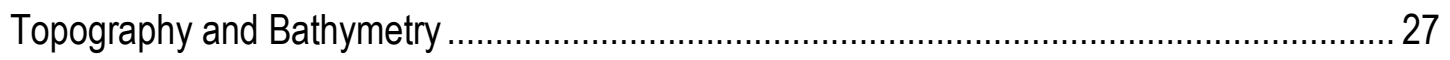

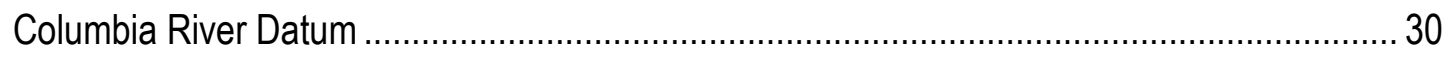

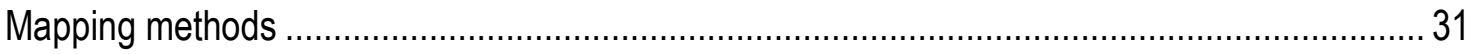

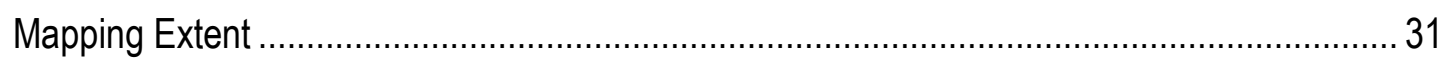

Geomorphic Catenae and Ecosystem Complexes .............................................................. 33

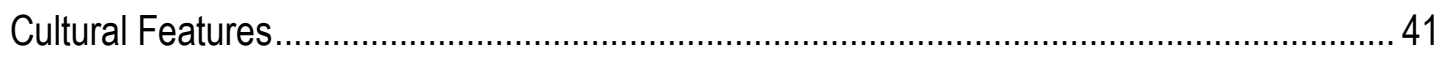

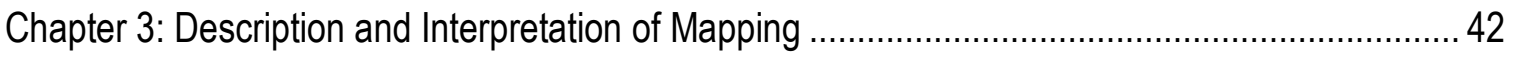

Channel and Backwater Complexes ……………………................................................. 42

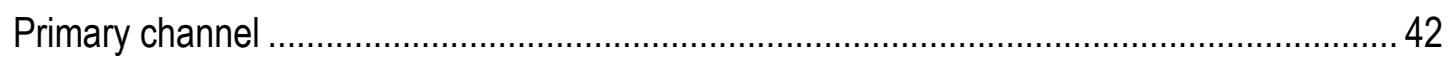

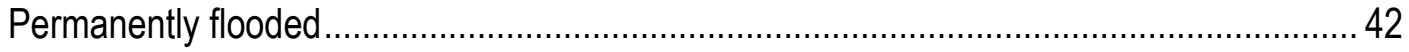

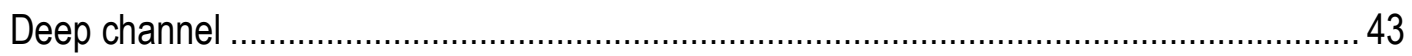

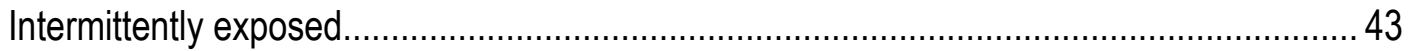

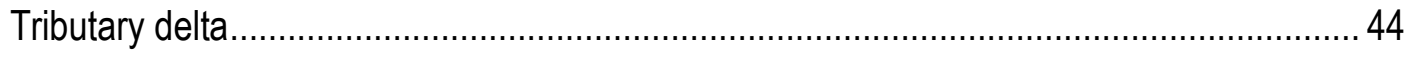

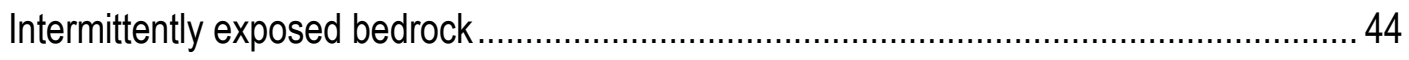

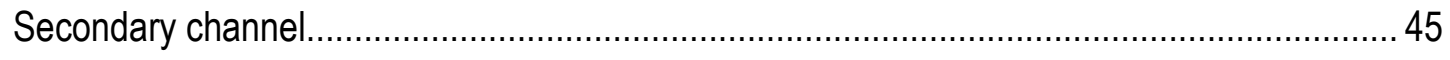

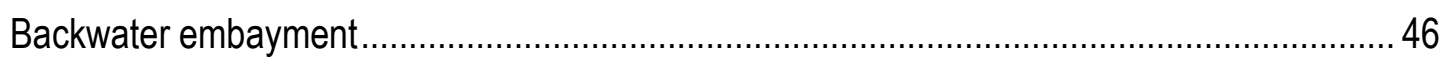

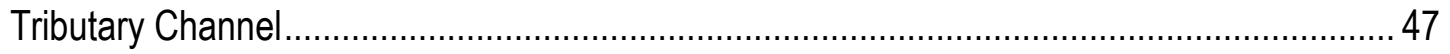

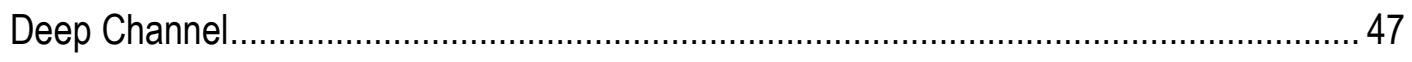

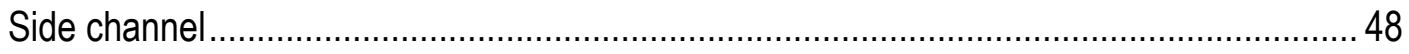




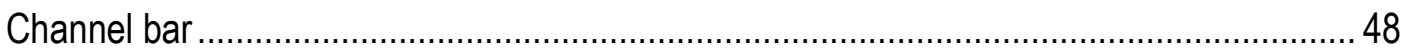

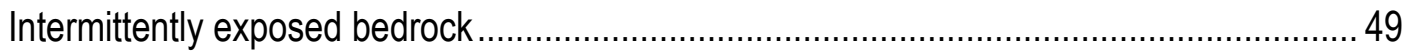

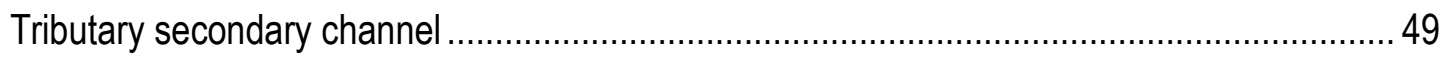

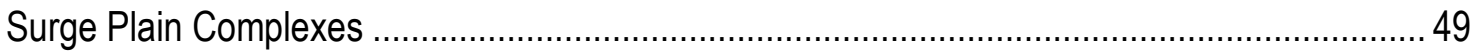

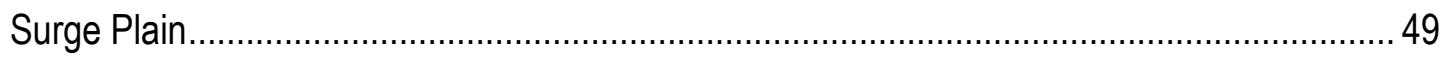

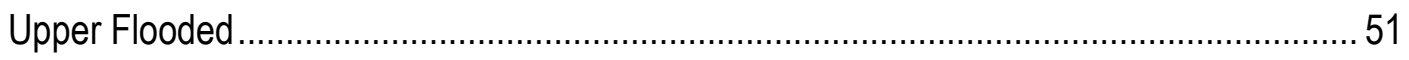

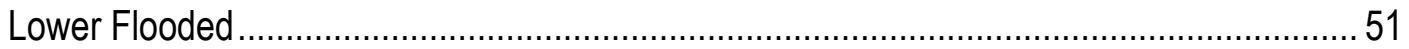

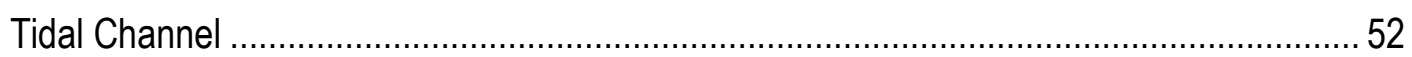

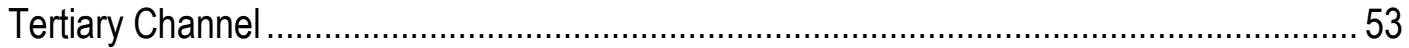

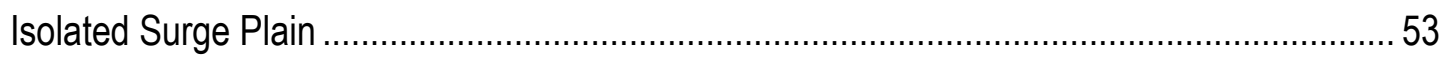

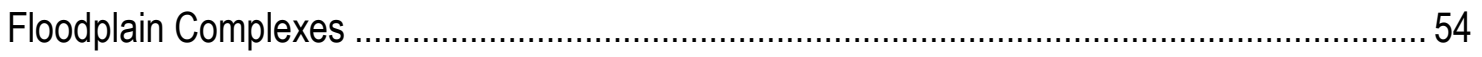

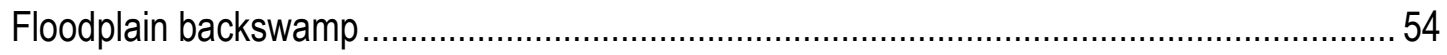

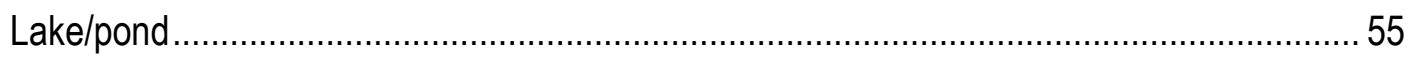

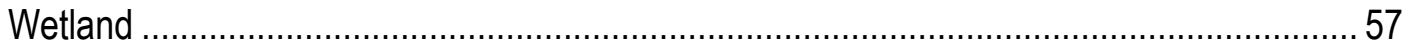

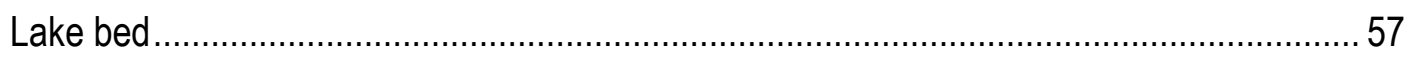

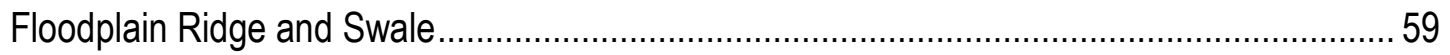

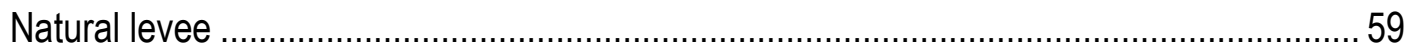

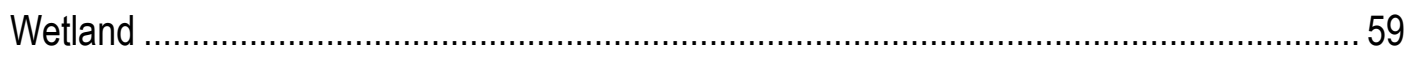

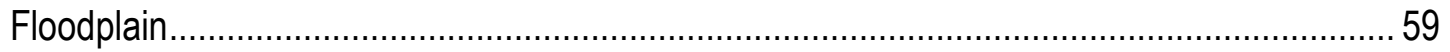

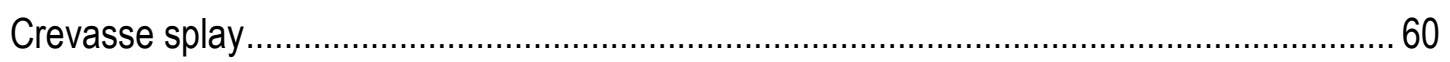

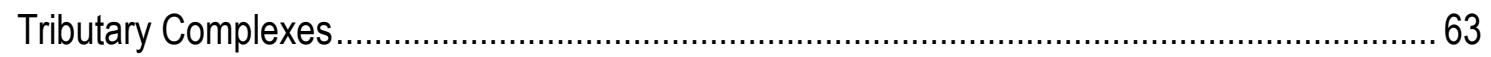

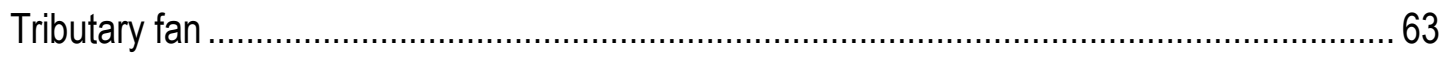

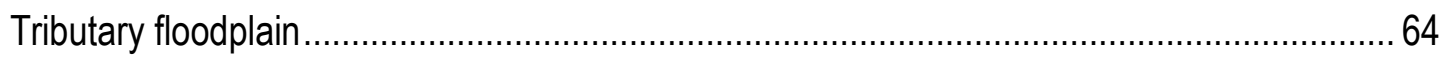


Volcanogenic delta

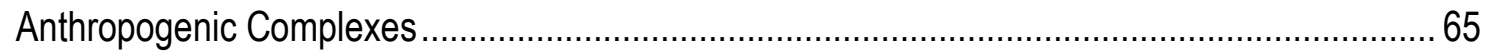

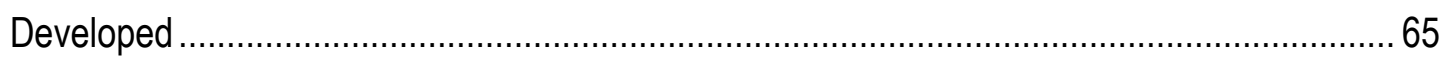

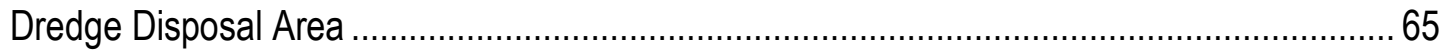

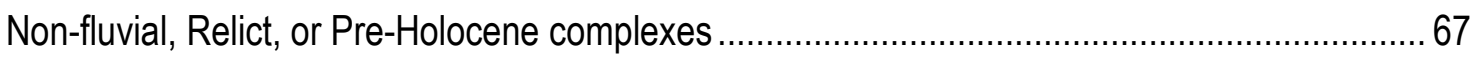

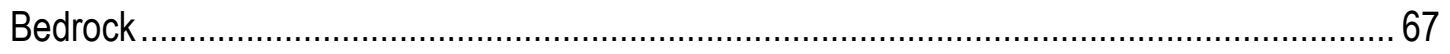

Dune

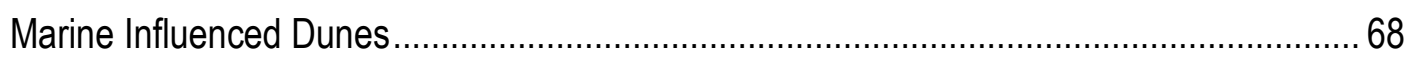

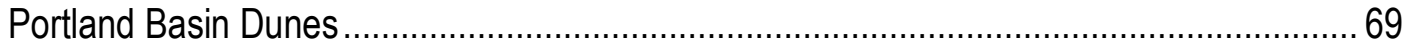

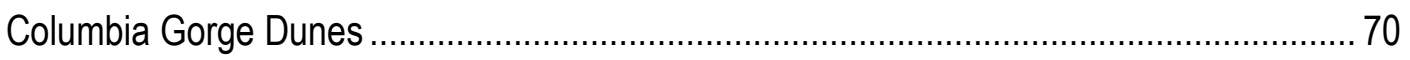

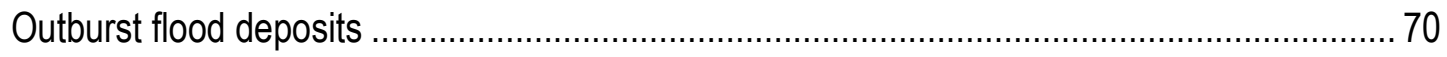

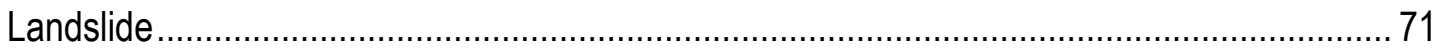

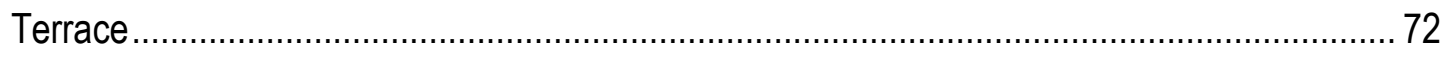

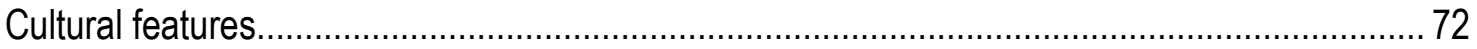

Chapter 4: Assessments of widespread anthropogenic influence ............................................. 76

Effects of changed hydrograph and isolation on hydroperiod ............................................. 76

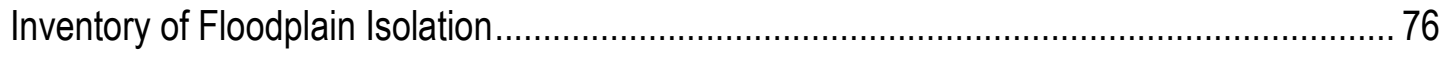

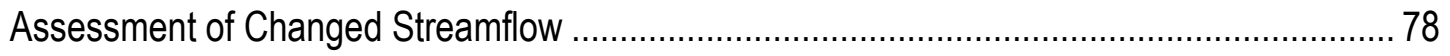

Effects of changed hydrograph and isolation on hydroperiod.............................................. 82

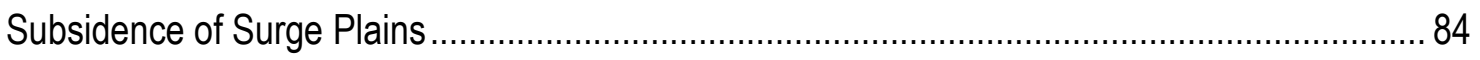

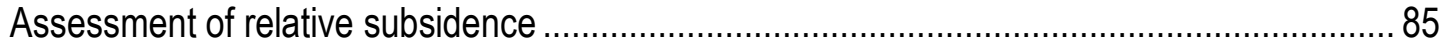

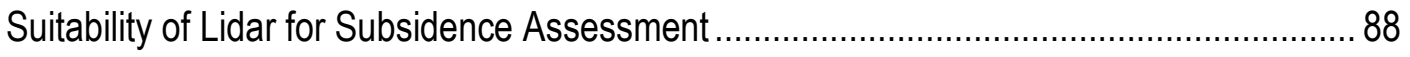

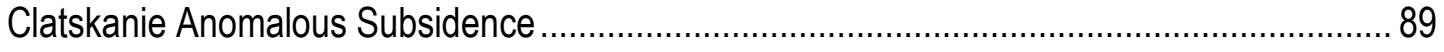


Lateral Erosion and Deposition.

Changes in distribution of deep channel and/or thalweg..................................................... 95

Chapter 5: Summary and Conclusion ....................................................................................... 96

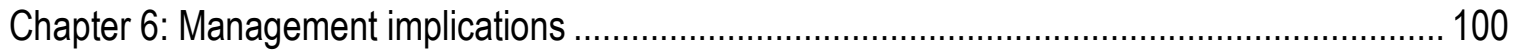

Chapter 7: Opportunities for Future Work............................................................................ 100

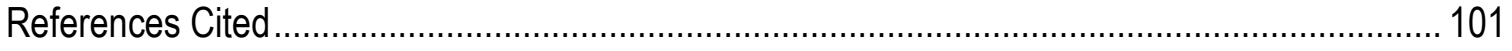

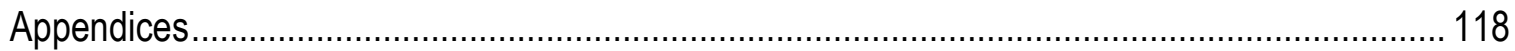

Appendix A. Area and Distribution of Ecosystem Complexes ................................................... 118

Appendix B. Areas of Accretion and Erosion since earliest U.S. Coast and Geodetic Survey

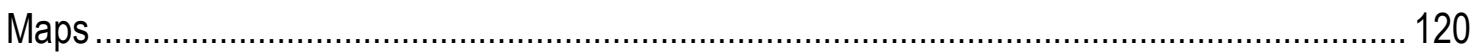




\section{List of Figures}

Figure 1. Columbia River basin showing tectonic setting and generalized geologic provinces......... 4

Figure 2. Simplified geography of western part of Columbia River study area between Pacific

Ocean and Longview, Washington

Figure 3. Simplified geography of eastern part of Columbia River study area between Longview,

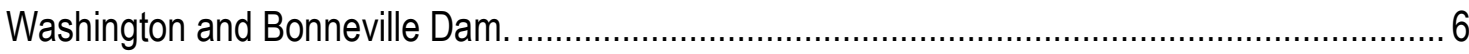

Figure 4. Boxplots showing daily mean streamflow percentiles by month at U.S, Geological Survey 14105700 (Columbia River at The Dalles, OR) gage for four Pacific Decadal Oscillation phases (PDO)

Figure 5. Selected historical flood profiles and Columbia River Datum (CRD) from U.S. Army Corps of Engineers (1968) adjusted to North American Vertical Datum of 1988 (NAVD 88)...... 11

Figure 6. Boxplots showing water level variability at stations along the Columbia River for modern high (June, 2011) and low (September, 2009) flow calendar months

Figure 7. Hourly water levels at Columbia River stations A. below Bonneville Dam, Oregon; B. Vancouver, Washington; C. Longview, Washington; and D, Astoria, Oregon over a lunar month (full moon to full moon) from March 9 to April 6, 2012 14

Figure 8. Streamflow at USGS 14105700 (Columbia River at The Dalles, OR) gage showing annual range of observed flows and for water years 1879-2013, with maximum virgin flows estimated by Naik and Jay $(2005,2011)$ for water years $1879-2004$ 15

Figure 9. Overview of the study area showing the eight hydrogeomorphic reaches from the Columbia River Estuary Ecosystem Classification of Simenstad and others (2011). 17

Figure 10. Valley-bottom width measured at 1-km intervals 21 
Figure 11. Average elevation of floodplain and surge plain landforms summarized by Columbia River Mile, excluding water bodies and mapped cultural features 23

Figure 12. Part of U.S. Coast and Geodetic Survey (1877) T-1455b near Kalama River confluence showing landcover interpretations from Burke (2010) ......................................................... 30

Figure 13. Illustration of terrain visualization methodology used to map landforms ........................ 35

Figure 14. Part of U.S. Department of Agriculture soils map (Ruzek and Carpenter, 1919) showing floodplain lakes and wetlands near Portland, Oregon and Vancouver, Washington...................56

Figure 15. Excavation near edge of the lake bed of Little Sturgeon Lake (historical) ..................... 58

Figure 16. Sturgeon Lake, Oregon showing Gilbert River crevasse splay features ........................ 63

Figure 17. Dredging near Longview, Washington in response to Mount St. Helens eruption. ........ 67

Figure 18. Median daily streamflow at The Dalles, Oregon for pre- and post-regulation periods.... 79

Figure 19. Map showing classification of isolated areas and locations of water-level measurement stations used to create statistical water surfaces 80

Figure 20. Part of U.S. Coast and Geodetic Survey T-sheet 1235 showing historical land cover along Prairie Channel near Brownsmead, Oregon as mapped in 1870 87

Figure 21. Surge plains and isolated surge plains along Prairie Channel near Brownsmead, Oregon symbolized by classified elevation.

Figure 22. Habitat improvement efforts along the Grays River involve breaching flood-control levees and excavating a tidal channel 


\section{List of Tables}

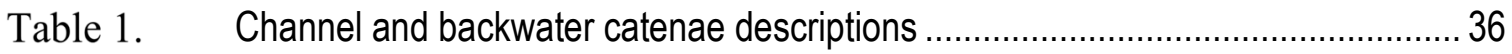

Table 2. Surge plain geomorphic catenae descriptions ................................................. 37

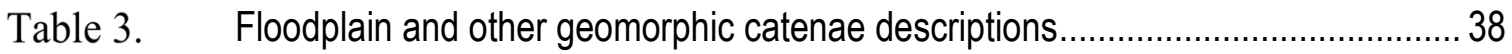

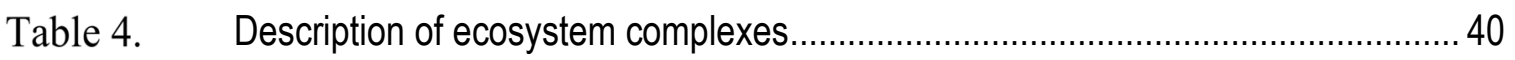

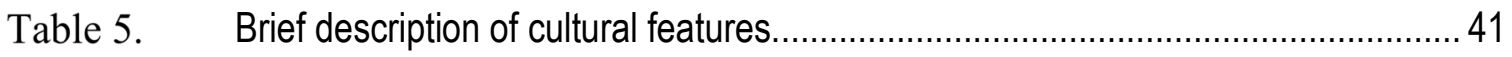

Table $6 . \quad$ Area of ecosystem complexes with more than $1 \mathrm{~km}^{2}$ of isolated area .................... 77

Table 7. Streamflow scenarios used to assess changes in potential inundation.................. 81

Table 8. Potential and actual inundation of ecosystem complexes below maximum water

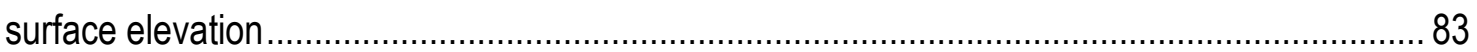

Table 9. Sites used to assess subsidence of isolated surge plains ................................... 86 


\section{Landforms along the Columbia River estuary and the influence of humans}

\section{Chapter 1: Introduction}

River systems in much of the world have been influenced by human activities, commonly resulting in changes to processes such as streamflow, sediment transport, and river-floodplain connectivity (Meybeck, 2003, Wohl and others, 2005). These physical processes influence the creation, maintenance, and destruction of landforms that form along rivers and their connected coastal systems.

The Columbia River is a regulated large-river system that includes 235 river kilometers of riverine estuary (Simenstad and others, 2011). The intent of this thesis is to describe the landforms along the tidally influenced reaches of the lower Columbia River and assess the influence of humans on landform evolution. This work is part of the Columbia River Estuary Ecosystem Classification (hereafter referred to as “Classification") proposed by Simenstad and others (2011). My contribution to the Classification was the interpretive mapping of floodplain landforms along the Columbia River estuary. Interpretive mapping is used as a basis from which to assess the effects of changed physical process regimes including floodplain isolation, subsidence of surge plains (tidal floodplains), changed hydroperiod, and channel alterations. After introducing Classification structure and the setting of the lower Columbia River, I separately describe the methods and results for each of these analyses.

\section{Columbia River Estuary Ecosystem Classification}

The Classification is a six-level hierarchical classification applied to the Columbia River estuary in a collaborative effort between University of Washington School of 
Aquatic and Fishery Sciences, U.S. Geological Survey, and Lower Columbia Estuary Partnership. The Classification provides an inventory of contemporary landforms along the estuary. The hierarchical nature of the Classification provides insight into formative processes of landforms and enables assessment of whether landscape elements are relict or in-sync with currently functional inundation and flow regimes.

The Classification progressed from coarse, regional scales to local landform and vegetation patches: (1) Ecosystem Province; (2) Ecoregion; (3) Hydrogeomorphic Reach; (4) Ecosystem Complex; (5) Geomorphic Catena; and (6) Primary Cover Class. Levels 1 and 2 are broad regional-scale classifications adapted from U.S. Environmental Protection Agency Ecoregions and will not be further elaborated on in this thesis. Levels 3 through 5 entailed new interpretative mapping specific to the Columbia River estuary. Level 3 is a division of the estuary study area into kilometer-scale valley-bottom reaches. Levels 4 and 5 are the main body of this thesis. Level 4, ecosystem complex represents groupings of landforms associated with the same set of formative processes. Level 3, geomorphic catena refers to the landforms within ecosystem complexes. Level 6, primary cover class, is an automated image-based object classification of land cover that will not be further discussed in this thesis. In addition to channel and landform mapping, cultural features with topographic expressions were mapped and classified as to their purpose when constructed. 


\section{Setting of the Columbia River Basin and Estuary}

\section{Drainage Basin and Geologic Setting}

The Columbia River drains about $673,000 \mathrm{~km}^{2}$ of western North America (Figure 1), flowing 2,000 km from Columbia Lake in the Rocky Mountain Trench of southeastern British Columbia, to the Pacific Ocean near Astoria, Oregon. It is the largest North American river by discharge to enter the Pacific Ocean (Milliman and Farnsworth, 2011). Most of the Columbia River drainage basin is in the Northern Rocky Mountains and Columbia Plateau physiographic provinces of Fenneman and Johnson (1946).

Geologic provinces in the Columbia River Basin include the Northern Rockies, Columbia Plateau, Middle Rockies, Basin and Range, Idaho Batholith, Snake River Plain, Cascade Range, North Cascades, Thompson-Okanogan Plateau, Puget-Willamette Trough, and Coast Range. The basin includes parts of Idaho, Oregon, Washington, British Columbia, and small areas of Montana, Nevada, Wyoming, and Utah. The estuary forms part of the border between Washington and Oregon and traverses the Portland-Vancouver metropolitan area. The Columbia River drains toward the leading edge of a convergent tectonic margin, cutting through the Cascades arc. Within the estuary study area (Figures 2 and 3), the river crosses the Cascade Range, the Puget-Willamette (forearc) trough, and the Coast Range. Because of this tectonic setting, external processes such as volcanism, seismicity, and mass movements influence sedimentary processes and valley-bottom landforms along the estuary. 


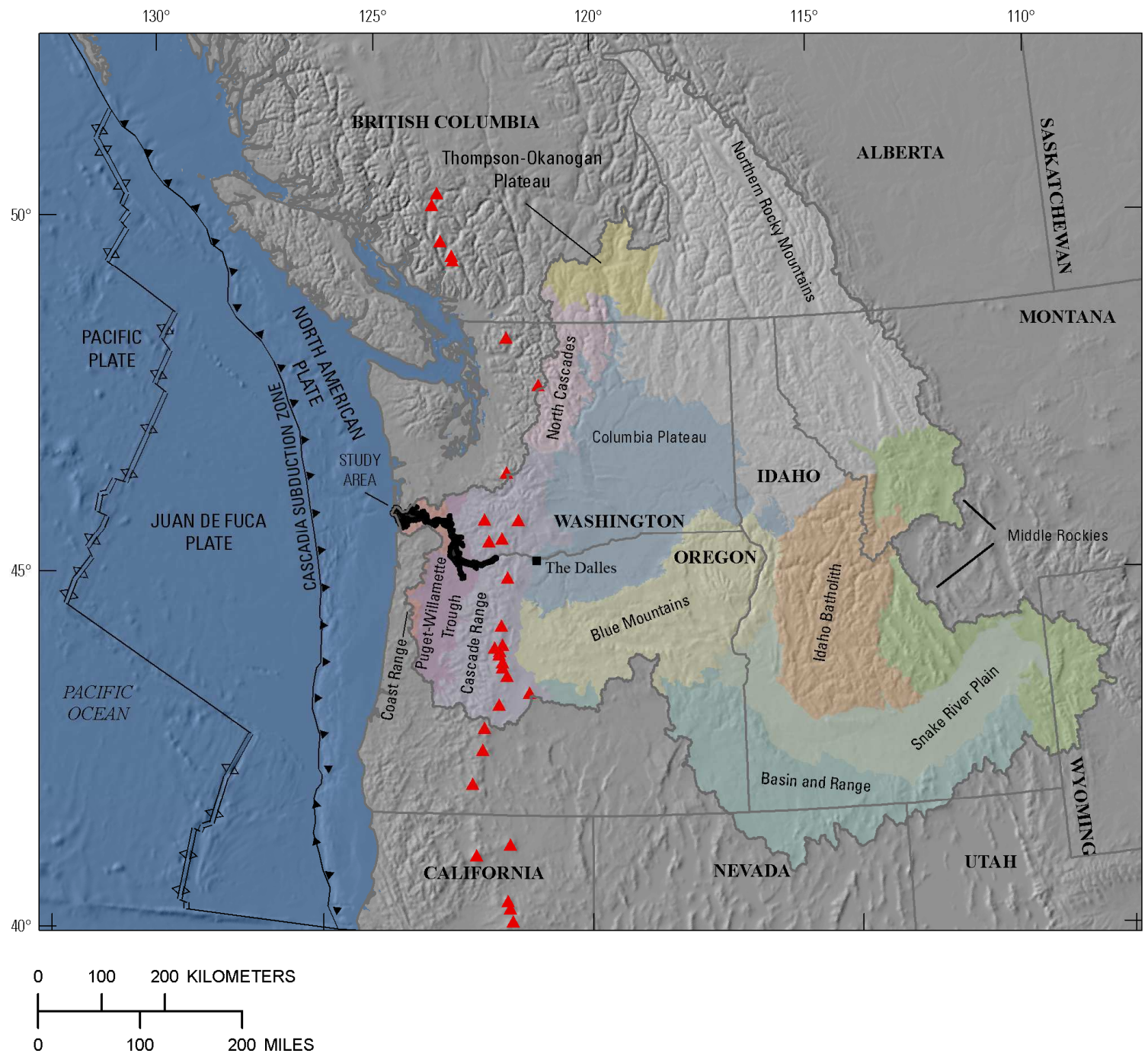

Figure 1. Columbia River basin showing tectonic setting and generalized geologic provinces. Red triangles are Quaternary Cascades arc volcanoes. Hollow teeth indicate direction of plate spreading. Filled teeth indicate direction of descending Juan de Fuca Plate. Study area of this work is dark shaded. Geologic provinces are modified from EPA Level III ecoregions. 


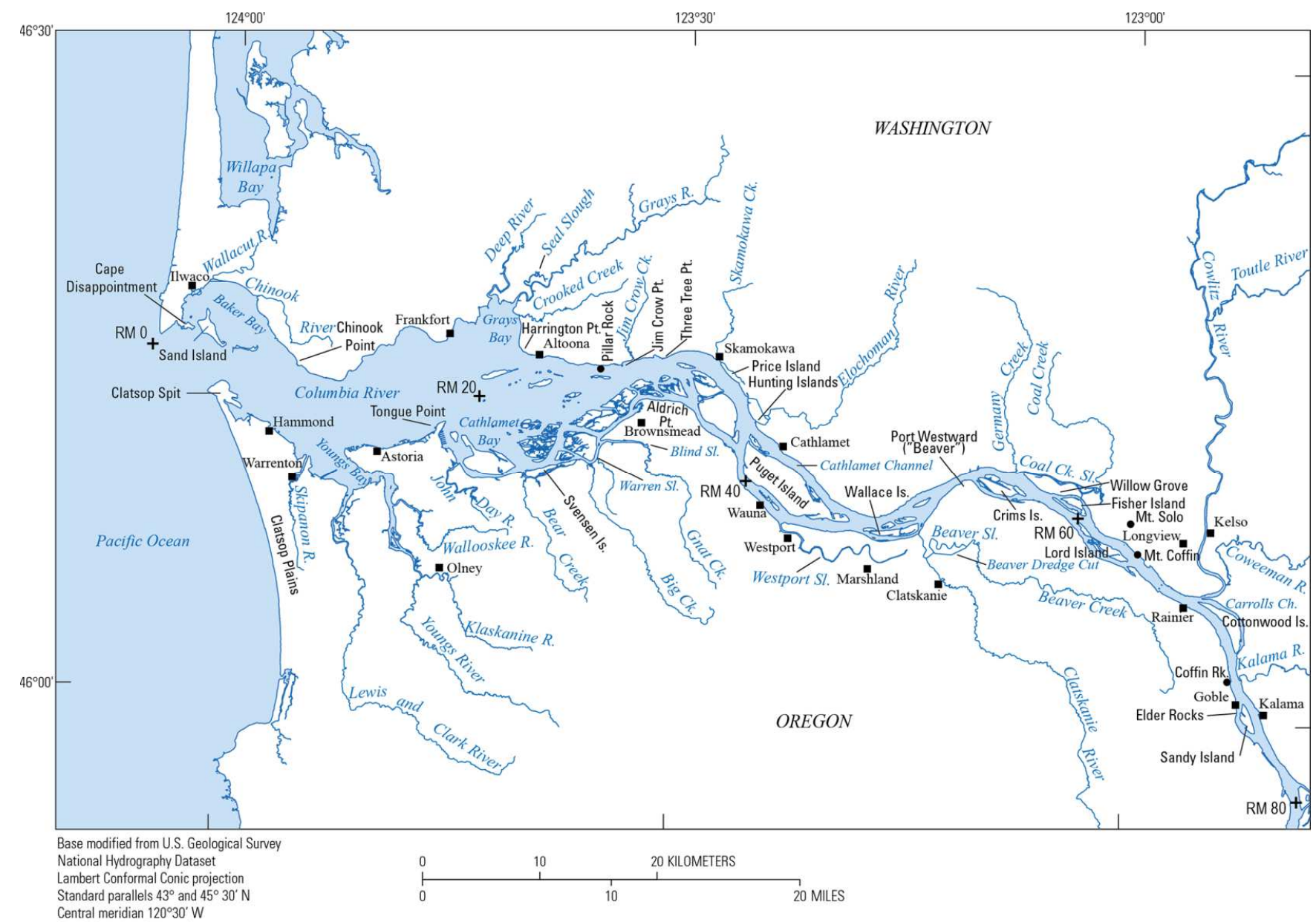

Figure 2. Simplified geography of western part of Columbia River study area between Pacific Ocean and Longview, Washington. [Abbreviations: R, River; RM, river mile; Is, Island; Ch, Channel; Rk, Rock; Pt, Point; Ck, Creek] 


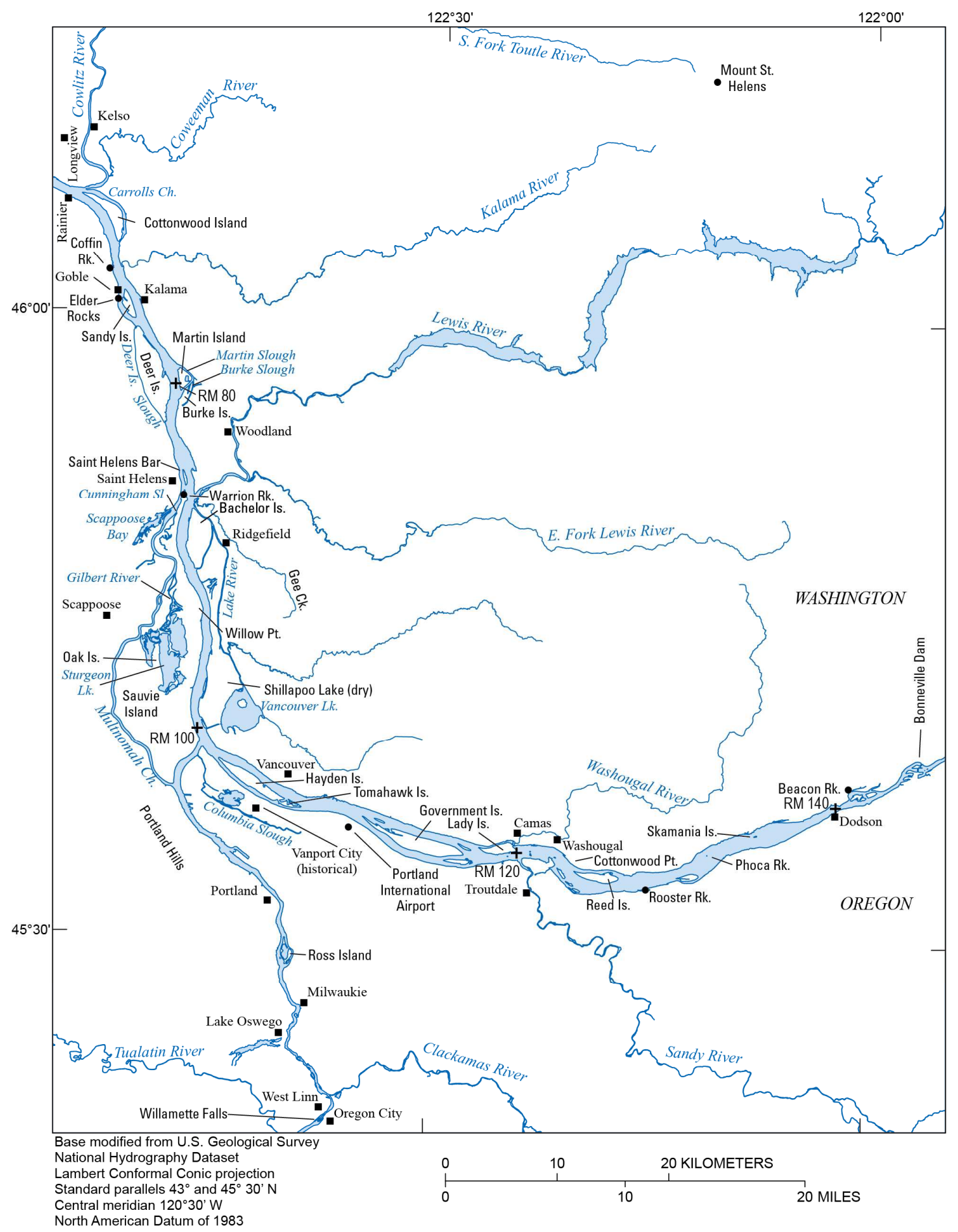

Figure 3. Simplified geography of eastern part of Columbia River study area between Longview, Washington and Bonneville Dam. [Abbreviations:R, River; RM, river mile; Is, Island; Ch, Channel; Rk, Rock; Pt, Point; Ck, Creek] 


\section{Late Quaternary Geologic Setting}

The geologic setting of the modern Columbia River is a result of convergent margin tectonics and Holocene marine transgression. At the time of last glacial maximum, about $16 \mathrm{ka}$, the Columbia River occupied a valley incised about $110 \mathrm{~m}$ below present sea level near Warrenton, Oregon, and about $75 \mathrm{~m}$ below present sea level near Vancouver, Washington (Baker, 2002, Baker and others, 2010, Peterson and others, 2011). From about 20 to $15 \mathrm{ka}$ (Evarts and others, 2013), a recurring ice-dam and subsequent breaches caused a series of catastrophic floods in the upper basin that followed the Columbia River to the ocean (Bretz, 1969). Known as the Missoula floods, these torrents locally eroded bedrock and other material, and left extensive sediment deposits in the Portland Basin (Evarts and others, 2009). Since the last glacial maximum, global sea level has risen and the valley has filled in with sediment (Baker, 2002; Peterson and others, 2011). Most modern floodplain sediment along the estuary was deposited within the past 2,000 years (Evarts and others, 2013, Peterson and others, 2014).

Hydrology

Basin hydrology

The Cascade Range is commonly used to divide the Columbia River Basin into dry interior and wet western sub-basins because of hydrologic differences (for example, Naik and Jay, 2011), and, the divide can be considered to be near The Dalles, Oregon, where the U.S. Geological Survey has collected streamflow data since 1878. Most Columbia River streamflow is from melting winter snow that collects in the Rocky 
Mountains and in the Cascade Range. About $24 \%$ of this streamflow originates from west of the Cascade Range crest (Sherwood and others, 1990), mostly from the Willamette and Cowlitz rivers, which drain parts of the Puget-Willamette forearc trough and west slopes of the Cascade Range. Mean annual streamflow at the mouth is about 7,000 $\mathrm{m}^{3} \mathrm{~s}^{-1}$ (Naik and Jay, 2005, 2011).

Basin hydrology is affected by variability from El Niño Southern Oscillation and Pacific Decadal Oscillation climate cycles. El Niño-Southern Oscillation (ENSO) conditions in the equatorial Pacific are associated with warm, wet climate in the Pacific Northwest every 3 to 8 years and cold, dryer climate ("La Niña") in the off-cycle (Ropelewski and Halpert, 1986). Pacific Decadal Oscillation (PDO) is driven by seasurface temperatures in the North Pacific Ocean that create oscillating warm/dry and cool/wet climate periods every 20 to 30 years that affect coastal ocean temperatures, streamflow, and biological productivity in western North America (Mantua and others, 1997; Naik and Jay, 2011; Figure 4). 


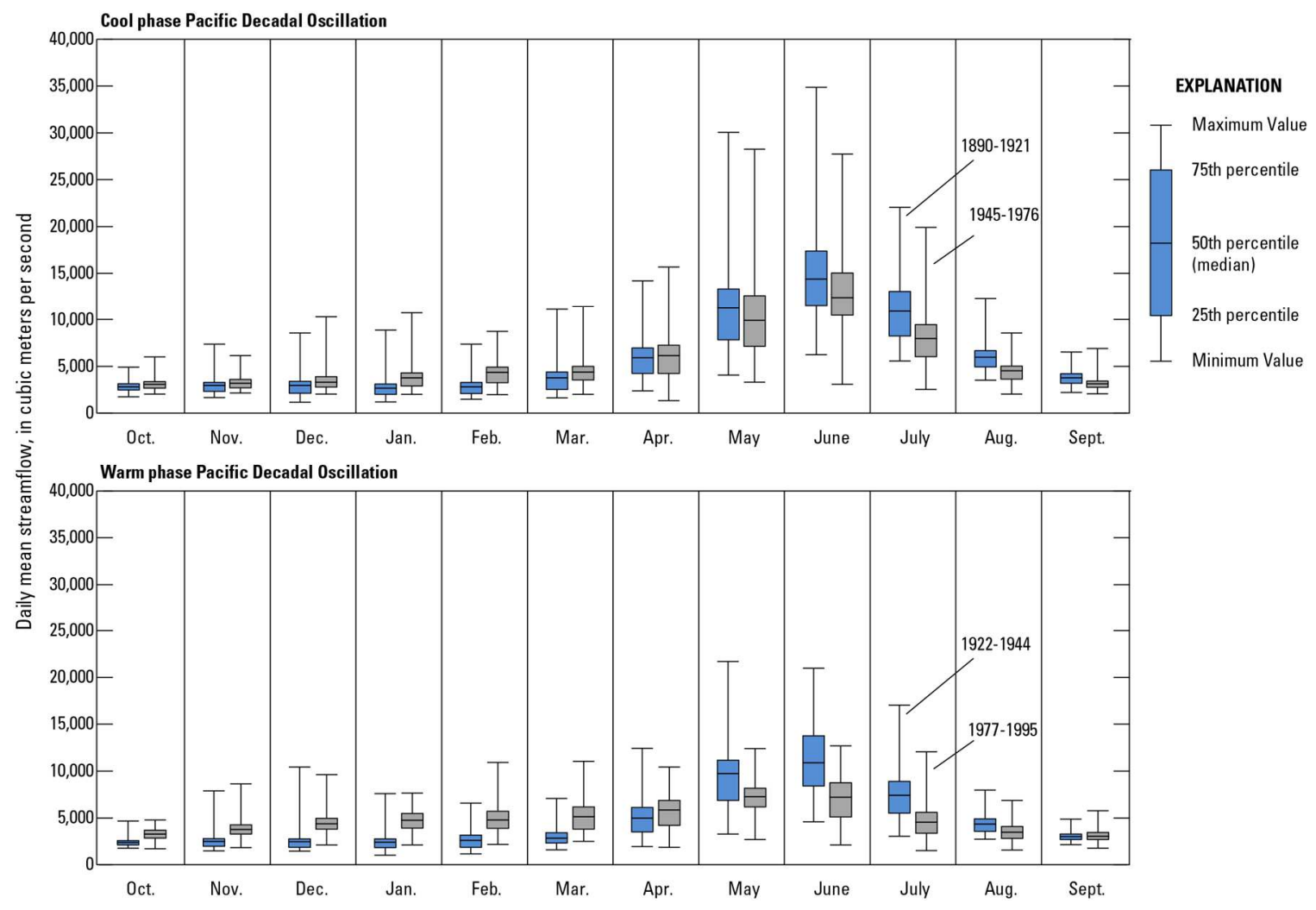

Figure 4. Boxplots showing daily mean streamflow percentiles by month at U.S, Geological Survey 14105700 (Columbia River at The Dalles, OR) gage for four Pacific Decadal Oscillation phases (PDO). PDO phases are from Naik and Jay (2011), and determined from winter (October to March) values of PDO indices (Mantua and others, 1997).

Historical Floods

Spring floods were historically a primary agent of geomorphic change. The biggest historical floods have been freshets (rain or snow-melt caused floods) that mostly occur in May and June. They are primarily from snow melt in the mountains of the interior basin and have notably longer durations than rainfall-fed floods. The duration and magnitude of spring freshets is affected by differences in snow melt. Typically, snow melt in the southern interior basin (Middle Rockies and Idaho Batholith) begins earlier than in the northern interior basin (Northern Rockies) and there is an extended freshet, historically even lasting until August (Naik and Jay, 2011). If the northern and southern 
sub-basins melt near simultaneously, or when widespread heavy rain accelerates snow melt, floods are shorter in duration, but are more voluminous (Naik and Jay, 2011).

Spring freshet floods in late spring of 1894 and 1948 are the largest historically observed floods and were both preceded by abnormally cold winters with above average snowfall leading to deep snow pack in the mountains. May and June of both years were unusually warm and excess snowmelt runoff was exacerbated by heavy rainfall in the upper (northern) Columbia River Basin.

The 1894 flood set the record for highest recorded streamflow of $35,000 \mathrm{~m} \mathrm{~s}^{-1}$ at The Dalles, Oregon on June 6, 1894. Flooding caused widespread infrastructure damage in the upper basin and along the lower Columbia River. Near Bonneville Dam at the upstream end of the study area, the 1894 flood was nearly $17 \mathrm{~m}$ above North American Vertical Datum of 1988, or $13 \mathrm{~m}$ above the low water Columbia River Datum (Figure 5). The 1894 flood backed up the lower Willamette River, which at Portland was above flood stage for 57 days (Rantz and Riggs, 1949). Although lower than the flood of 1894 (Figure 5), the most monetarily disastrous flood along the lower Columbia River was the spring freshet of 1948. The backed-up Willamette River was above flood stage at Portland for 43 days (Rantz and Riggs, 1949). Along the estuary, flood-control levees were breached, including at Puget Island, Clatskanie, Woodland, Portland international Airport, and Vanport, Oregon (Rantz and Riggs, 1949; Willingham, 1983). Peak streamflow recorded at The Dalles was $29,000 \mathrm{~m}^{3} \mathrm{~s}^{-1}$. 
River kilometer

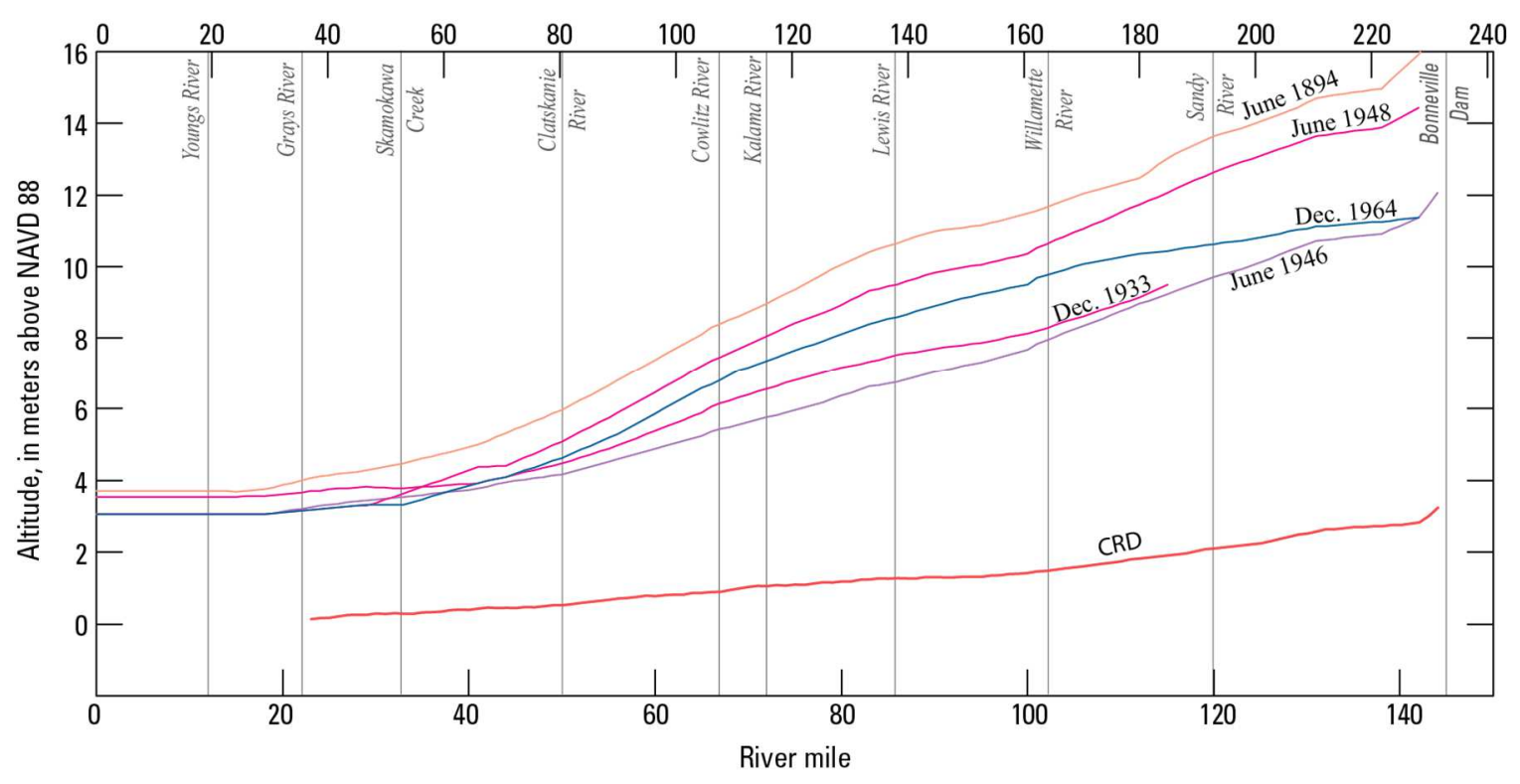

Figure 5. Selected historical flood profiles and Columbia River Datum (CRD) from U.S. Army Corps of Engineers (1968) adjusted to North American Vertical Datum of 1988 (NAVD 88). "River mile" is distance, in miles from the Columbia River mouth as shown on U.S. Geological Survey topographic maps.

Tributaries in the lower basin generally do not add substantially to spring freshets but occasionally produce large shorter-duration winter peaks. During winter, the Pacific Northwest is affected by narrow zones of warm moist air originating in the tropics or subtropics that can be thousands of kilometers long and approach from the southwest. Referred to as atmospheric rivers or "pineapple express", these bands of concentrated water vapor are the cause of most extreme precipitation events in western Oregon and Washington (Neiman and others, 2011; Warner and others, 2012). As atmospheric rivers rise over the steep terrain of the region, they can produce heavy rainfall. When atmospheric rivers follow cold wet periods with substantial snowpack accumulation, floods can be particularly large, such as the Willamette River flood of December 1861 (Wells, 1947) or the widespread flooding in 1964 and 1996. Because atmospheric rivers 
are relatively narrow (hundreds of kilometers), they do not always affect the whole region evenly. Floods of record were measured on the Cowlitz and Lewis rivers in 1933, whereas on the Clackamas and Sandy rivers, the highest flows were measured in 1964.

Tides

The tidal pattern affecting the estuary is mixed diurnal and semidiurnal with amplitude ranging from 2 to $4 \mathrm{~m}$ near Astoria (Kukulka and Jay, 2003) and decreasing eastward to less than $1 \mathrm{~m}$ at Vancouver (Figures 6 and 7) but still affecting water levels near Bonneville Dam during times of low streamflow. Tidal forcing has less effect when streamflow is high and upstream of Longview, is influenced by Bonneville Dam power generation cycles (Jay and others, 2014; Figure 7). Water levels during typical historical flood stages are tidally affected as far upstream as Saint Helens, Oregon, whereas the largest floods were not measurably affected by tidal forcing upstream of Longview, Washington (U.S. Army Corps of Engineers, 1968). Tidally forced current reversal in the primary channel penetrates at least as far as the Cowlitz River confluence during periods of very low streamflow (Clark and Snyder, 1969). 


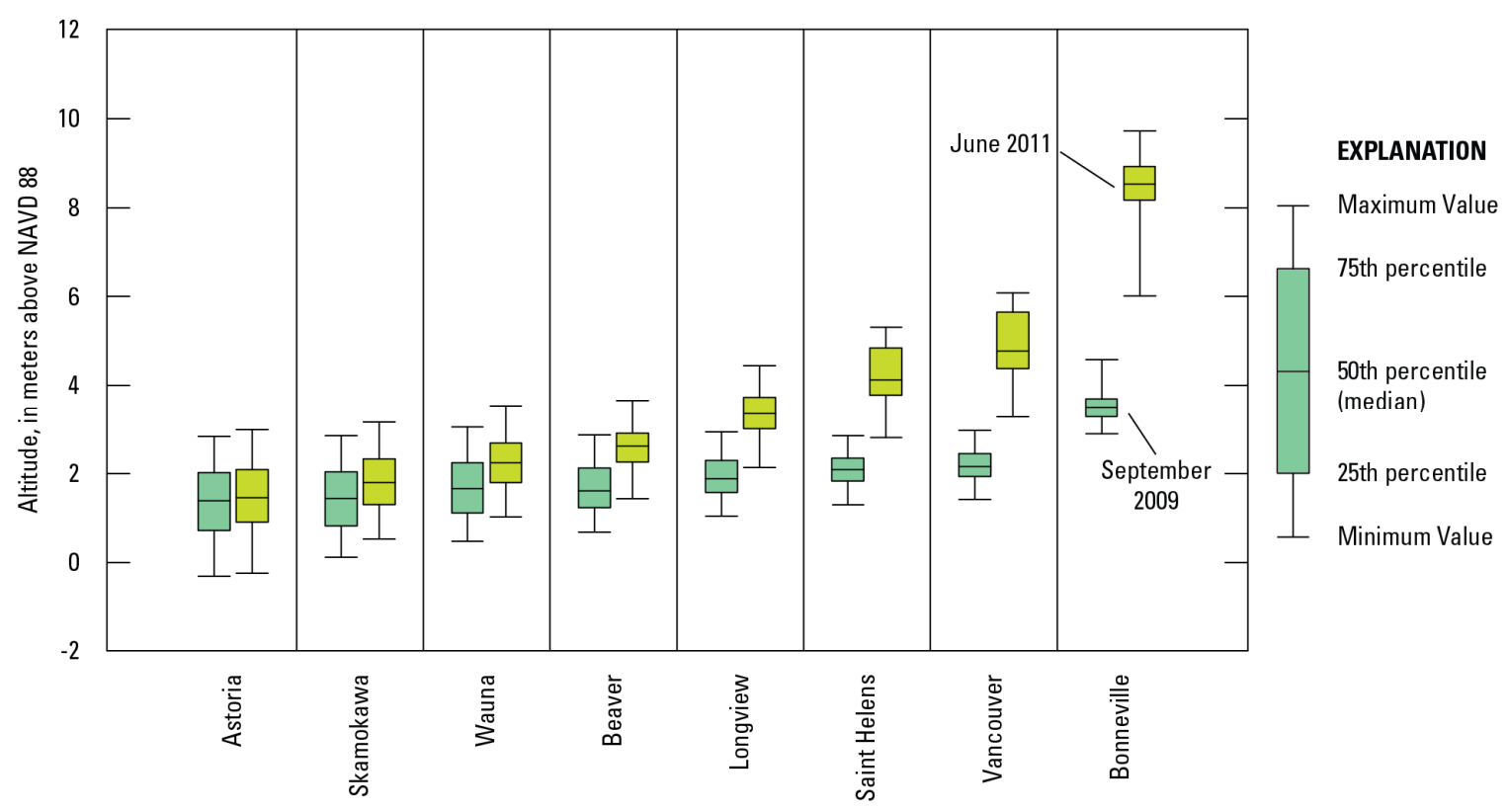

Figure 6. Boxplots showing water level variability at stations along the Columbia River for modern high (June, 2011) and low (September, 2009) flow calendar months. September 2009 water level variation is dominantly controlled by tides. Maximum streamflow at The Dalles was 15,000 and $3,110 \mathrm{~m}^{3} \mathrm{~s}^{-1}$ respectively. Statistics were computed from hourly water level measurements. 


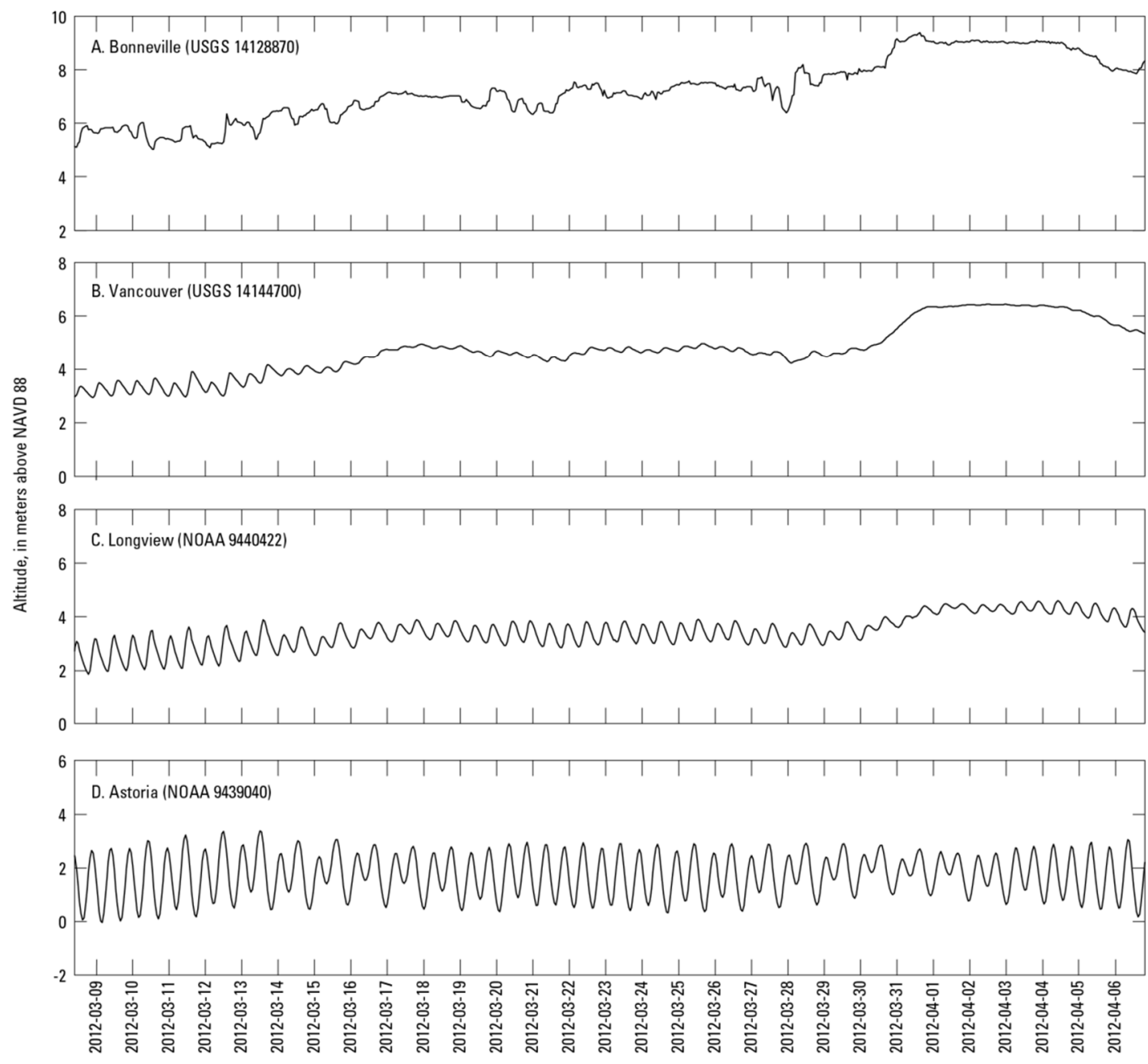

Figure 7. Hourly water levels at Columbia River stations A. below Bonneville Dam, Oregon; B. Vancouver, Washington; C. Longview, Washington; and D, Astoria, Oregon over a lunar month (full moon to full moon) from March 9 to April 6, 2012. [Abbreviations: USGS, U.S. Geological Survey; NOAA, National Oceanic and Atmospheric Administration]

Flow Regime Changes and Modern Hydrology

Columbia River streamflow is affected by an extensive network of dams built to enable flow regulation, electricity generation, and irrigation. Estimates of "virgin" streamflow (effects of flow regulation and irrigation withdrawal removed) by Naik and Jay (2005) indicate that irrigation withdrawals and climate change have caused an 
approximately $15 \%$ reduction in water entering the estuary from the interior basin in an average year. Flow regulation has changed the timing of runoff, resulting in fewer extreme high or low flows. (Figures 4 and 8)

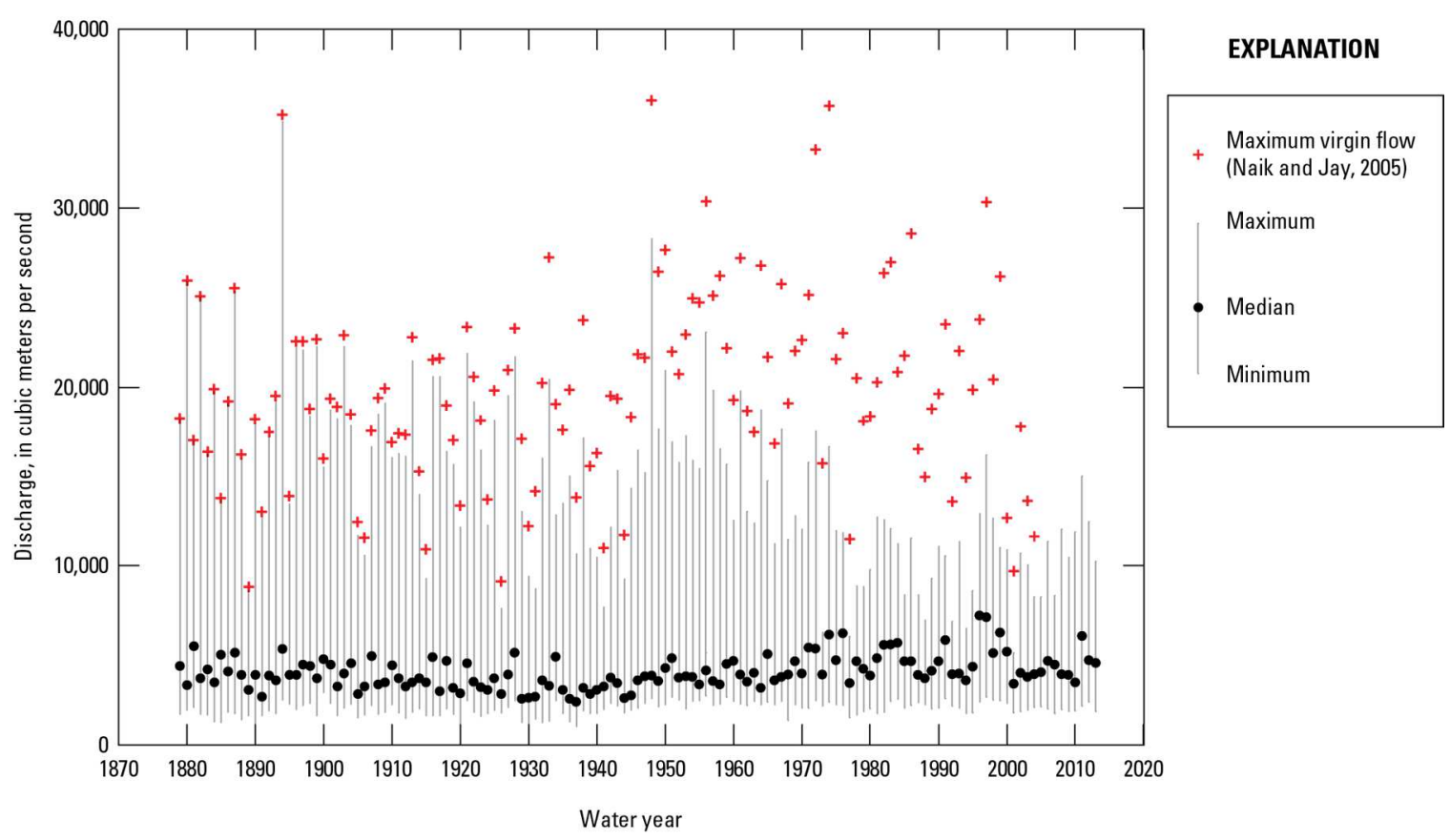

Figure 8. Streamflow at USGS 14105700 (Columbia River at The Dalles, OR) gage showing annual range of observed flows and for water years 1879-2013, with maximum virgin flows estimated by Naik and Jay $(2005,2011)$ for water years $1879-2004$. Virgin flow refers to streamflow with the effects of flow regulation and irrigation withdrawal removed.

Sediment

Most natural landforms along the estuary floodplain are formed of sediment transported and deposited by the river. Most of this sand, silt, and clay enters the estuary from upstream or from tributaries. Near the mouth, some sediment enters the lower river from the ocean or by eolian transport from coastal beaches (Sherwood and Creager, 1990). Hindcast estimates of annual transport rates range from more than $35 \times 10^{6} \mathrm{~m}^{3} \mathrm{yr}^{-1}$ 
for the 1894 big-discharge year to less than $2 \times 10^{6} \mathrm{~m}^{3} \mathrm{yr}^{-1}$ for some of the low-discharge post-regulation years (Gelfenbaum and others, 1999).

Most suspended load is fine sand or finer materials from the interior basin (Whetten and others, 1969) but also occasionally includes fine-grained material from Cascade arc eruptions (Hubbell and others, 1983). Most sediment in the estuary moves as suspended load, about $75 \%$ of which is transported to the ocean (Gelfenbaum and others, 1999). Suspended-load transport rates are supply-limited, and thus are a function of watershed sediment supply processes.

Bedload is mostly volcanic rock fragments from the Cascade arc (Whetten and others, 1969). Since most of the channel-bottom is sand covered, bedload movement is considered to be transport capacity-limited and is thus a function of streamflow (Sherwood and others, 1990; Niak and Jay, 2011). During high streamflow bed material can be entrained into suspension, leading to substantial sand transport in suspension (Haushild and others, 1966).

Hydrogeomorphic Reaches

Hydrogeomorphic reaches are the coarsest estuary-specific level of the Classification and represent broad scale geologic and hydrologic processes. The reaches were modified from EPA Ecoregions by University of Washington based on broad scale physiography, fluvial-tidal hydrologic factors, and tributary confluences (Simenstad and others, 2011). The following descriptions are modified from Simenstad and others (2011) to summarize reach physiography, geologic setting, and relevant large-scale process domains such as tides, relative sea level change, tectonics, and wind. Each reach is given 
a letter designation (for example "Reach A", Figure 9) and will be referred to by these designations throughout this thesis.

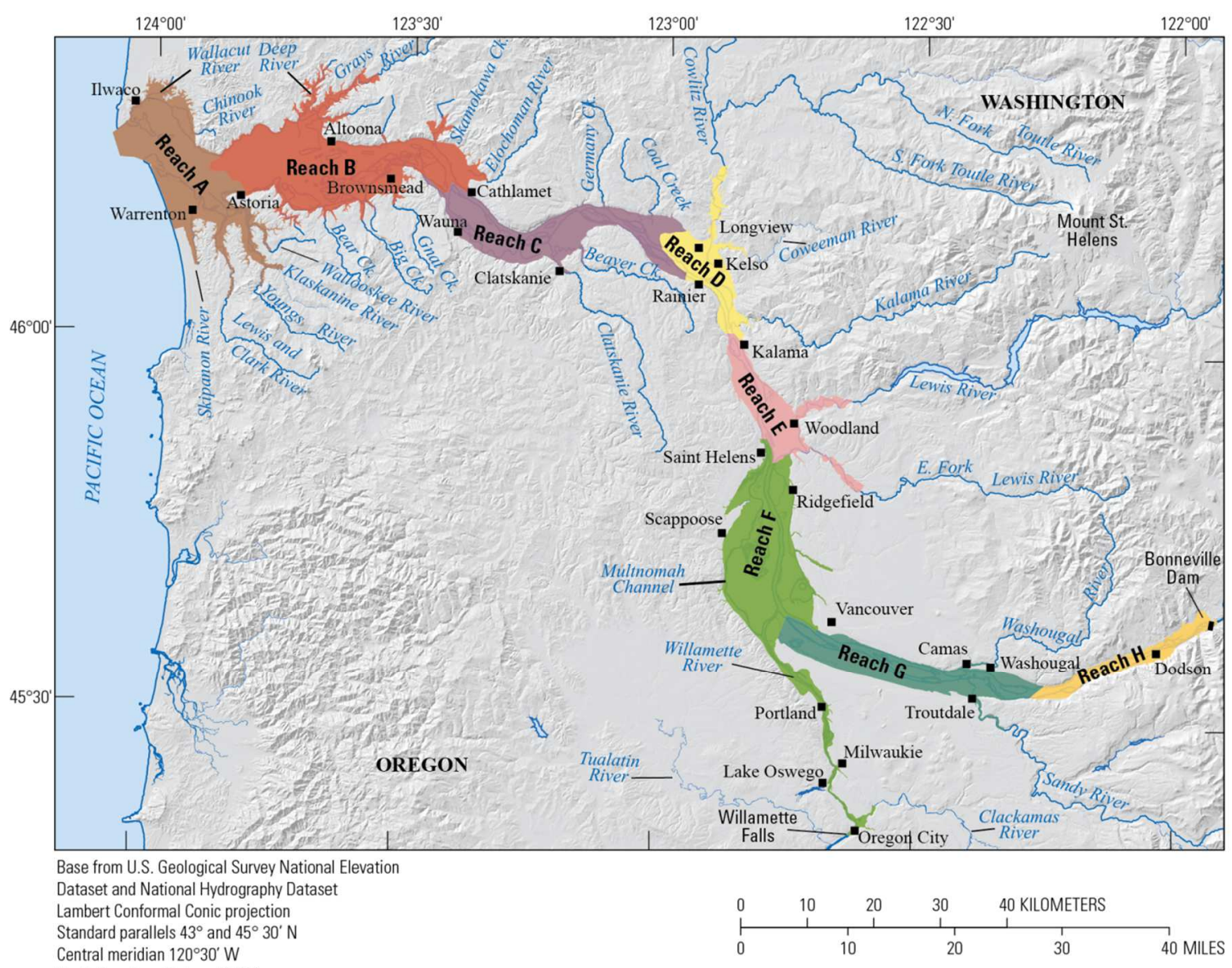

North American

Figure 9. Overview of the study area showing the eight hydrogeomorphic reaches from the Columbia River Estuary Ecosystem Classification of Simenstad and others (2011).

\section{Reach A}

Reach A is modified from the EPA Level IV Coastal Lowlands ecoregion and extends from the river entrance to Astoria, Oregon. The reach is mostly bounded by Pleistocene terraces and Eocene to Miocene marine sedimentary rocks, but Eocene 
volcanic and volcaniclastic rocks are exposed at Cape Disappointment and near Chinook Point (Niem and Niem, 1985; Wells, 1989).

It is largely influenced by marine processes, including sediment transport by wind, waves, and tidal currents. This reach includes extensive tidal and formerly tidal reaches of the Youngs, Lewis and Clark, and Skipanon Rivers as well as part of the Clatsop Plains marine dune complex. Water salinity, velocity, and turbidity are affected by turbulent mixing of estuarine and oceanic waters across the estuary's entrance. High spring tides and storm surges can produce coastal flooding events.

During the summer, high-pressure off the coast interacts with a low pressure center (Rowson and Colucci, 1992) over southwestern North America and causes air flow from north to south along the coast of Oregon and Washington. During winter, the highpressure center moves south and interacts with a seasonally strengthened low pressure zone over the Aleutian Islands, causing air flow from south to north (Cooper, 1958; Ballard, 1964). Extra-tropical cyclones affect the Pacific Northwest coast and are most common during winter, generally approaching from the southwest (Mass and Dotson, 2010). Winds associated with extra-tropical cyclones can exceed $50 \mathrm{~m} \mathrm{~s}^{-1}$ and gusts as great as $68 \mathrm{~m} \mathrm{~s}^{-1}$ have been documented near the mouth of the Columbia River (Mass and Dotson, 2010). Knapp and Hadley (2011) infer from tree damage assessments that a cyclone described by Lewis and Clark in 1805 may have been more severe than any wind storms documented since Euro-American settlement.

During winter, Pacific Ocean wave heights near the mouth of the Columbia River average about $3 \mathrm{~m}$ with periods of 12 to 13 seconds, and approach from the southwest. During summer, wave heights average $1.2 \mathrm{~m}$ with periods of 8 seconds and approach 
from the west-northwest (Ruggerio and others, 2005). Average water level is about $30 \mathrm{~cm}$ higher during the winter (Ruggerio and others, 2005).

Reach A is periodically affected by disturbances associated with subduction zone earthquakes including tsunamis (Peterson and others, 1993; Petersen and others, 2003; Yeh and others, 2012; Tolkova, 2013) and coseismic subsidence (Peterson and others, 2000; Petersen and others, 2003; Atwater and others, 2004, Leonard and others, 2010). Between subduction zone earthquakes, the coastal margin is uplifted. Presently, uplift outpaces global sea-level rise, resulting in relative sea level fall of about $1 \mathrm{~mm} / \mathrm{yr}$ near the coast (Burgette and others, 2009, Komar and others, 2011).

Reach B

Reach B is mostly within the EPA Level IV Coastal Uplands ecoregion and extends from Astoria Oregon to Cathlamet, Washington. The reach includes the widest valley bottom in the study area (Figure 10) and is mostly bounded by Miocene marine and nearshore sedimentary rocks that are locally invaded by or interbedded between flows of the Miocene Columbia River Basalt Group (Wolfe and McKee, 1968; Murphy 1981; Niem and Niem, 1985; Wells, 1989; Wells and others, 2009). Landslide topography is common along the valley walls, particularly between Skamokawa, Washington and Harrington Point, where beds in marine sedimentary rocks dip toward the river (Wolfe and McKee, 1968).

This reach has the strongest salinity gradient, from mesohaline to oligohaline at the up-estuary extent of salinity intrusion. The maximum extent of salinity intrusion observed by Jay (1984) is near Pillar Rock, though he suggests it likely reaches as far as near Three Tree Point a few times a year. Water levels fluctuations are mostly influenced 
by tides, but are also seasonally influenced by streamflow (Jay and others, 2014). This reach has been described as a zone of minimum energy flux (Jay, 1984; Jay and others 1990) where tidal energy is roughly balanced by fluvial energy. A mosaic of surge plain (tidal floodplain) islands and tidally influenced channels form a bay head delta in the upstream half of Reach B and broad mostly isolated surge plains flank the eastuary near Cathlamet, Washington and Brownsmead, Oregon.

Tectonic uplift nearly balances sea-level rise in this reach with relative sea level fall of less than $0.5 \mathrm{~mm} / \mathrm{yr}$ at Tongue Point and sea level rise of about $0.4 \mathrm{~mm} / \mathrm{yr}$ near Brownsmead, Oregon (Burgette and others, 2009, Komar and others, 2011, Zervas and others, 2013). Coseismic subsidence from subduction zone earthquakes has been documented along the Columbia, Deep, Grays, and John Day Rivers in this reach, and between Tongue and Aldrich points may have been as great as 2 meters during the A.D. 1700 Cascadia megathrust earthquake (Peterson and others, 2000).

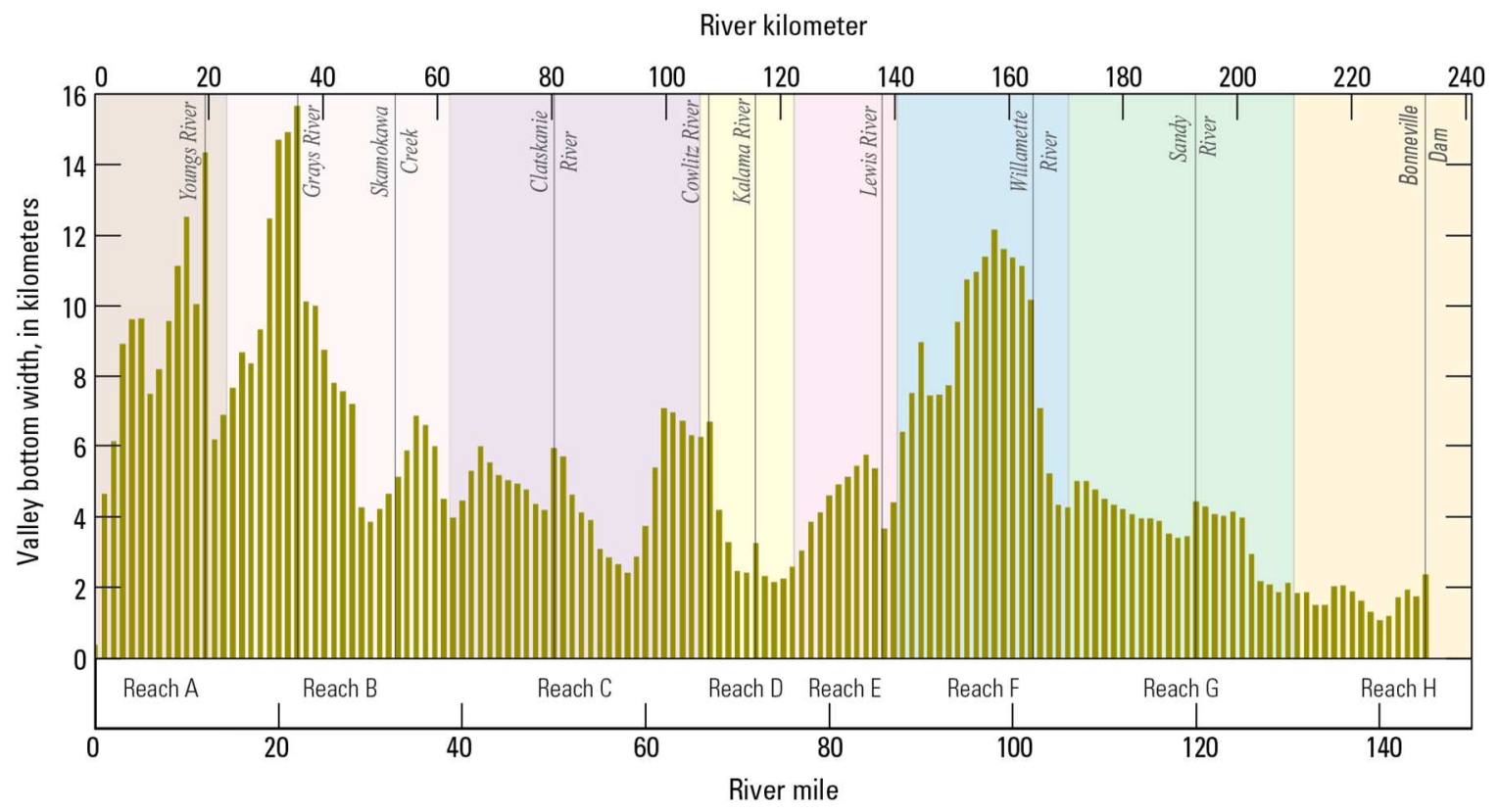


Figure 10. Valley-bottom width measured at 1-km intervals. Shading denotes extent of hydrogeomorphic reaches.

Reach C

Reach C is modified from the EPA Level IV Volcanics, Willapa Hills, and Coastal Uplands ecoregions and extends from Cathlamet, Washington to near Rainier, Oregon. Reach C extends through a confined valley that bisects the eastern Coast Range and is mostly bounded by flows of the Miocene Columbia River Basalt Group or Eocene Grays River Volcanics (Wells, 1981; Erikkson, 2002; McCutcheon, 2004). Along the south valley wall between Clatskanie and Wauna, the reach is bounded by landslides in Oligocene to Miocene shallow marine, estuarine, and fluvial deposits of the Pittsburg Bluff and Scappoose Formations (Niem and Niem, 1985; Walsh, 1987; Erikkson, 2002; Shaw and others, 2008).

Reach C has less water level variation than the other reaches (Jay and others, 2014), but like the reaches upstream of it has an energy regime dominated by fluvial energy (Jay and others, 1990). Mean diurnal range of tides decreases from $2.2 \mathrm{~m}$ at Wauna to $1.4 \mathrm{~m}$ at Longview. Most floodplain surfaces are low flat surge plains that have been isolated by flood-control levee systems.

Sea level rise outpaces tectonic uplift, resulting in average relative sea level rise of $1.5 \pm 0.4 \mathrm{~mm} \mathrm{yr}^{-1}$ from 1925 to 2006 (Burgette and others, 2009). Coseismic subsidence from subduction zone earthquakes has occurred in this reach at least as far upstream as Wallace Island near the Clatskanie River confluence (Atwater, 1994; Peterson and others, 2000; Petersen and others, 2003), and possibly as far inland as Longview, Washington (Peterson and Cruikshank, 2014) near the boundary with Reach D. 
Reach D

Reach D is modified from the EPA Level IV Cowlitz/Chehalis Foothills ecoregion, a part of the Puget Lowland and also includes part of the Willapa Hills Level IV ecoregion. The Columbia, as well as the lower Cowlitz, Coweeman, and Kalama valleys are mostly incised into Eocene to Oligocene Volcanic and Volcaniclastic rocks, including the Goble and Grays River Volcanics, but many floodplain margins abut late Miocene to late Pleistocene terrace deposits (Phillips, 1987; McCutcheon, 2004). Reach D contains the narrowest valley bottom downstream of the Columbia Gorge (Figure 10).

Columbia River current seldom reverses within this reach and average diurnal tidal range is between 1.0 and 1.4 meters. At the upstream end of Reach $\mathrm{C}$ and into Reach D, landforms transition from low flat surge plains to higher fluvial features (Figure 11). This reach receives episodic pulses of volcanogenic sediment from Mount St. Helens eruptions through the Cowlitz and Kalama River valleys (Crandell, 1987; Scott, 1988, 1989). These sediment pulses have likely contributed to broad volcanogenic deltas at the confluences of the Cowlitz and Kalama rivers. 
River kilometer

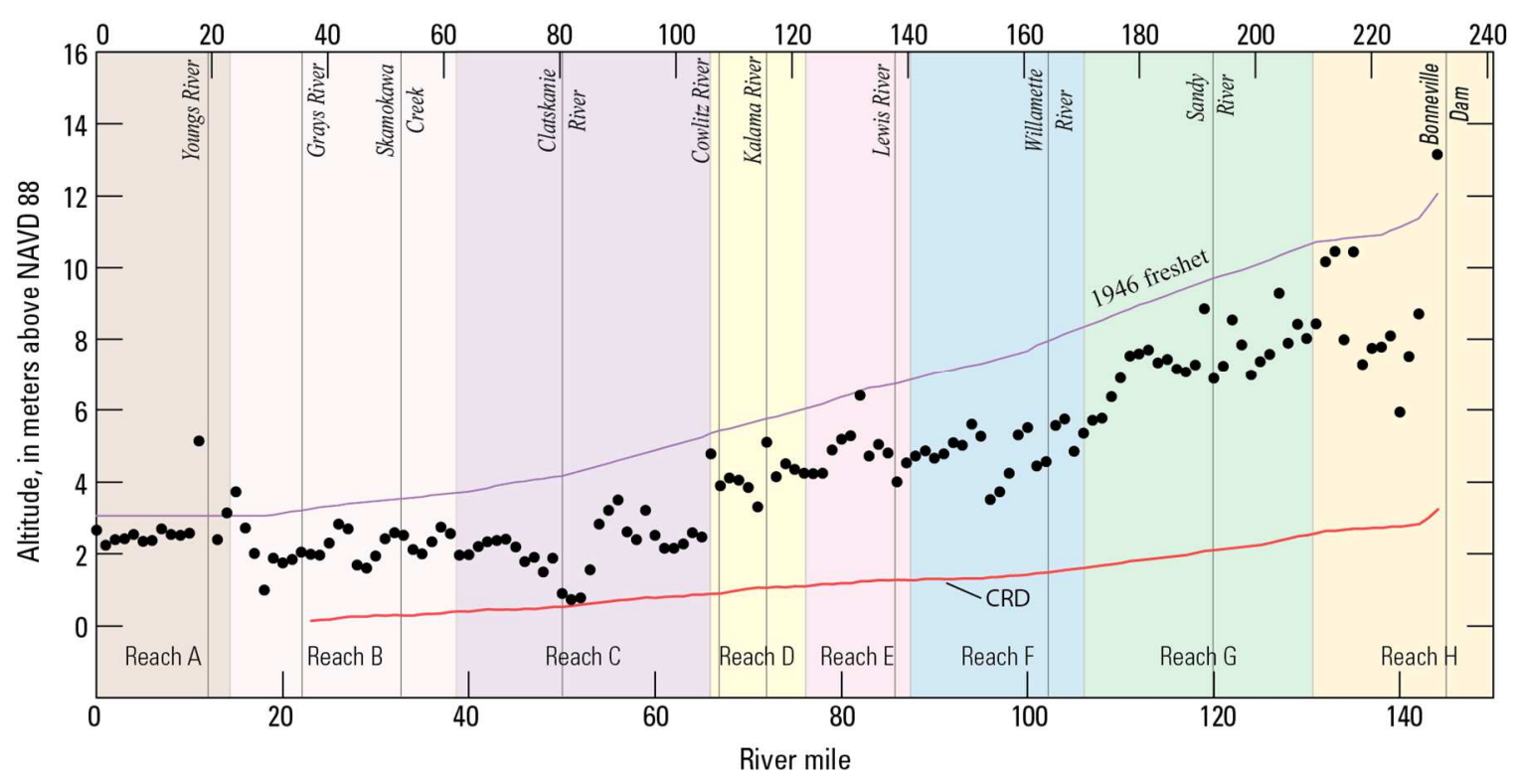

Figure 11. Average elevation of floodplain and surge plain landforms summarized by Columbia River Mile, excluding water bodies and mapped cultural features. The 1946 freshet flood profile is a typical pre-regulation spring flood. Columbia River Datum (CRD) is a low water datum for the Columbia River upstream of river mile 22.

Reach $\mathrm{E}$

Reach E is mostly within the Level IV Portland/Vancouver Basin ecoregion, but also includes parts of the Willapa Hills and Cowlitz/Chehalis Foothills ecoregions. The Columbia River valley in this reach is incised into Eocene to Miocene volcanic and volcaniclastic rocks, including the Goble Volcanics and flows of the Columbia River Basalt Group. Mean diurnal tide range is $1.0 \mathrm{~m}$ at St. Helens near the upstream end of the reach but is greatly diminished during high flows. Pleistocene terrace deposits flank much of the floodplain margin, particularly near the upstream end of the reach. The Lewis River has conveyed volcanogenic debris to the Columbia River from eruptions of Mount St. Helens, including large volume inputs about 2,500 and 500 years ago that have built out a broad volcanogenic delta (Vogel, 2005) and pushed the Columbia River 
channel against the west valley wall (Gates, 1994). A prominent feature of Reach E is Deer Island, a large floodplain island of sub-parallel ridges and swales.

Reach F

This reach is part of the Level IV Portland/Vancouver Basin ecoregion and includes the Columbia River valley between the Willamette and Lewis River confluences and the Willamette River below Willamette Falls. The reach is along the west edge of the Portland Basin, where it is bounded by Columbia River Basalts that have been uplifted by the Portland Hills anticline (Evarts and others, 2009). The reach is mostly bounded on the east by ancestral Columbia River deposits overlain by late Pleistocene Missoula Flood deposits (Evarts and others, 2009), but parts of the Willamette River upstream of Portland are incised into flows of the Miocene Columbia River Basalt Group or Eocene basalt of Waverly Heights (Beeson and others, 1989; Popowski, 1997).

Reach F includes the widest valley bottom upstream of Reach B (Figure 10). The floodplain below Portland was historically composed mostly of backswamp lakes and wetlands separated from channels by natural levees and areas of ridge and swale topography. Many of the backswamps have been filled in for port and industrial development or isolated by flood-control levee systems. Numerous rock outcrops are present along the Willamette River above Portland and at the downstream end of the reach near Saint Helens, Oregon. Diurnal tidal range at Vancouver is $1.0 \mathrm{~m}$, and during times of very low flow, water levels can fluctuate by about 1 meter at Oregon City, below Willamette Falls. 
Reach G

Reach G is mostly in the EPA Level IV Portland/Vancouver Basin ecoregion and extends from near Vancouver, Washington to the western entrance of the Columbia Gorge. Reach $\mathrm{G}$ is incised into Pleistocene fluvial deposits, including those from the Missoula Floods. The Sandy and Washougal rivers confluences are in the eastern end of the reach. Mount Hood has been a source of volcanogenic sediment, mainly by way of the Sandy River, which has been affected by the Polallie (15 to $12 \mathrm{ka}$ ), Timberline (1.8 to 1.4 ka; A.D. 300-600) and Old Maid (A.D. 1781 to about 1793) eruptive periods (Rapp, 2005; Pierson and others, 2011). Mid-channel islands (for example, Government and Reed Islands) appear to have been formed within the last 500 years (Evarts and O’Connor, 2008), likely growing in a downstream direction. Similar to Reach F, this reach was historically composed largely of floodplain backswamps separated from channels by natural levees but most have been filled in for development or isolated by flood-control levee systems. Diurnal tide range at the downstream end of the reach is 1.0 $\mathrm{m}$ and decreases upstream, where it is commonly obscured by streamflow and the power peaking cycles of Bonneville Dam.

Reach $\mathrm{H}$

This reach is mostly within the Level IV West Cascades Lowlands and Valleys ecoregion and encompasses the western Columbia Gorge from near Rooster Rock to Bonneville Dam. This narrow reach has incised into uplifted volcanic and volcaniclastic rocks of the Cascade Range and flows of the Columbia River Basalt Group during the last 3-3.5 Ma (Evarts and others, 2009) and is mostly bounded by large landslide and alluvial fan complexes, as well as bedrock cliffs. A few narrow floodplains with lakes 
and wetlands are in the downstream lee of large landslide and alluvial fan deposits. The A.D. 1415-1445 Bonneville Landslide dammed the Columbia River near the upstream end of the reach (O'Connor, 2004). Sometime before A.D. 1479, the landslide dam breached, possibly producing a peak streamflow as great as $110,000 \mathrm{~m}^{3} / \mathrm{s}\left(\mathrm{O}^{\prime} \mathrm{Connor}\right.$, 2004; O’Connor and Burns, 2009). Dune ridges near Rooster Rock (Rapp and others, 2002) coincide with the west end of the Columbia Gorge wind gap where strong winter easterly winds reach their greatest velocities (Sharp and Mass, 2004). The influence of the tides on water levels is much less than that of the power peaking cycle created by discharges from Bonneville Dam (Jay and others, 2014). 


\section{Chapter 2: Geomorphic Mapping}

\section{Source Data for Geomorphic Mapping}

Multiple information sources provided the base for geomorphic mapping. Most fundamental are a topographic and bathymetric digital terrain model. Historical maps, aerial photographs, geologic maps, soils maps were also important, as well as information from previously published reports.

\section{Topography and Bathymetry}

The primary base data layer is the digital terrain model that consists of Light Detection and Ranging (lidar) topography merged with various bathymetry sources. Lidar Data were collected from December 2009 to February 2010. Above Longview, Washington, lidar data were mostly collected when streamflow at Bonneville Dam was less than mean daily streamflow. Downstream of Longview, lidar data were collected when water levels were below the lower of the two daily high tides. Accuracy of the lidar topography was assessed by spot-checking prominent points and is estimated to be within $13 \mathrm{~cm}$ (David C. Smith and Associates, 2011).

The lidar topography was merged with bathymetry data that included surveys collected from 1851 to 2010 by various methods and with varying resolution. Most of the bathymetry data were from multibeam sonar collected between 1990 and 2010 (USACE, 2010). The topographic and bathymetric data were integrated into a single, seamless elevation model for the lower Columbia River. Gridded data sets derived from the terrain model have a 1-m horizontal resolution and are the primary elevation information used in the mapping and analysis. 
Land cover classification (Lower Columbia River Estuary Partnership, 2011) was based on integrated high resolution image segmentation and object based classification, mostly from 2009 National Agriculture Imagery Program aerial imagery supplemented with lidar topography, and Landsat Thematic Mapper 5 imagery. Land cover was in places useful for mapping and analysis of geomorphic catenae, particularly for tidally influenced floodplains.

The primary aerial photographs used were digital orthophotographs acquired as part of the National Agriculture Imagery Program (NAIP) and provided as county mosaics. For Oregon counties, the imagery was acquired June 23 to June 27, 2009 and for Washington counties, the imagery was acquired from August 1, 2009 to September 11, 2009. In places, historical conditions were assessed using USGS aerial photographs from the 1950s and U.S. Forest Service aerial photographs from 1930.

U.S. Coast and Geodetic Survey topographic and hydrographic maps (T-sheets and $\mathrm{H}$-sheets respectively) were used to assess historical conditions downstream of Rooster Rock. These maps are field surveys that were carried out along the Columbia River from 1868 to 1901 for the production of nautical charts. T-sheets are topographic field surveys representing the features above the "high-water line" as well as along-shore features (such as rocks) and were constructed at the time of survey using a plane table and alidade, "eliminating the necessity of retaining field notes for later plotting in the office" (Shalowitz, 1964). T-sheets represent topography as elevation contours and show vegetation, wetlands, water bodies, and cultural features. $\mathrm{H}$-sheets are representations of the area below the plane of high water and consist of soundings and bottom conditions recorded during hydrographic field surveys that are later plotted on a map (Shalowitz, 
1964). Interpretations of historical land cover (as polygons) were made from T-sheets by Burke (2010, Figure 12) and enabled me to assess historical change. USGS topographic maps from 1897 to 1995 with scales from 1:62,500 to 1:24,000 were used to assess historical conditions and landform function as well as to identify cultural features.

Statewide digital geologic map compilations for Washington (Washington Division of Geology and Earth Resources, 2008) and Oregon (Ma and others, 2009) as well as numerous other geologic maps (for example, Wolfe and McKee, 1968; Murphy, 1981; Wells, 1981; Beeson and others, 1989; Wells, 1989; Errikson, 2002; Evarts, 2002; Evarts, 2004a; Evarts, 2004b; Evarts, 2004c; McCutcheon, 2004; Evarts and O'Connor, 2008; Evarts and others, 2013) and field guides (O’Connor and Burns, 2009; Wells and others, 2009) were used to identify landforms within and adjacent to the floodplain.

The U.S. Fish and Wildlife Service National Wetlands Inventory (NWI, 2009 version) digital compilation of wetland habitats was used as an indicator of wetlands. The NWI is based on USGS 1:24,000 scale topographic maps and aerial photographs, and because of relatively low spatial resolution and potentially outdated content, it was generally not used as a sole indicator of wetland location and extent. U.S. Department of Agriculture, Natural Resources Conservation Service (NRCS) digital soils mapping was used to identify material properties of landforms, and as an indicator of generalized hydrologic conditions, such as protection from flood or tidal inundation, and artificial drainage. 


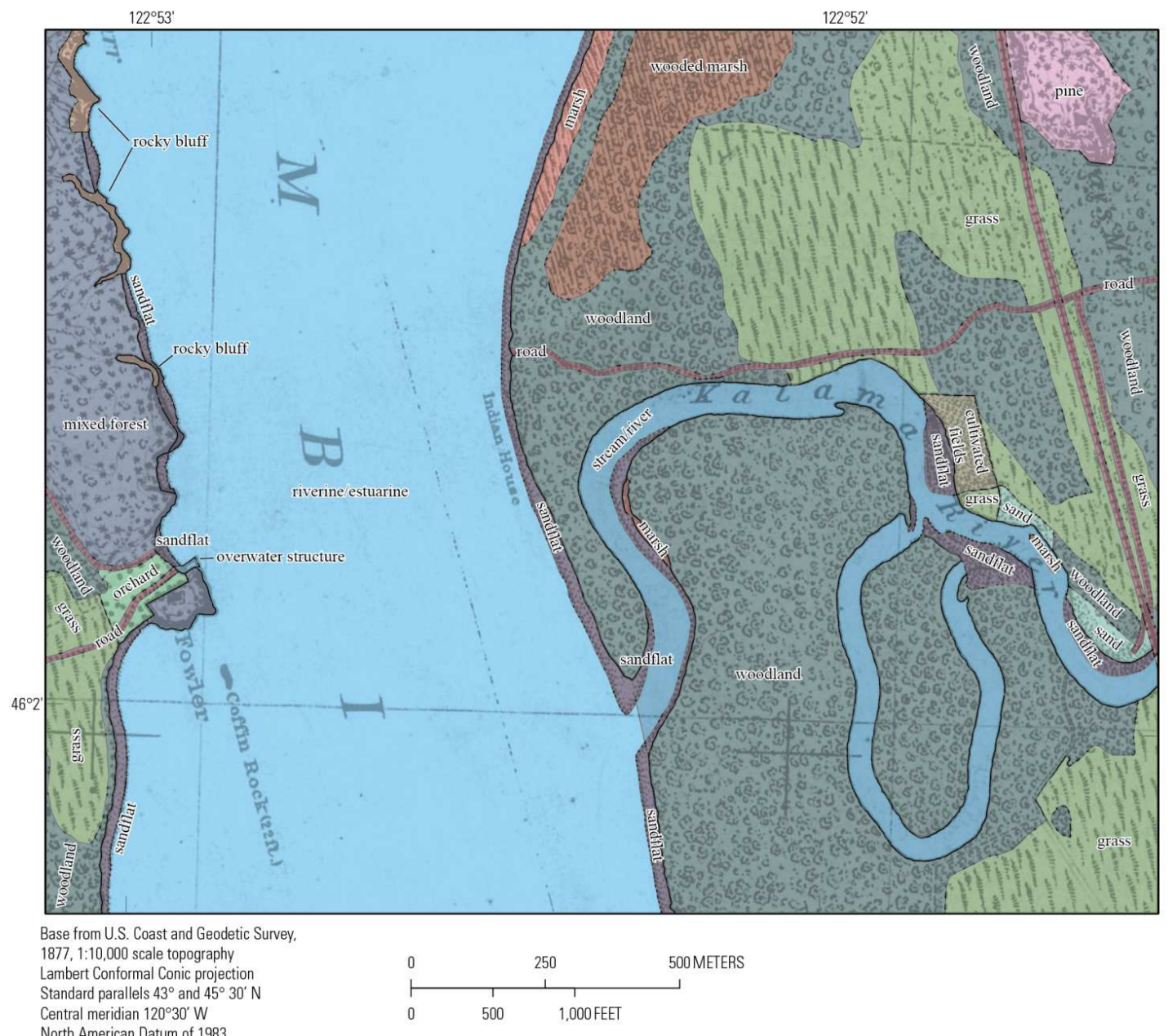

Figure 12. Part of U.S. Coast and Geodetic Survey (1877) T-1455b near Kalama River confluence showing landcover interpretations from Burke (2010)

Columbia River Datum

The Columbia River Datum (CRD) was used to adjust terrain model elevations and to increase mapping consistency. CRD is a fixed low water datum used on the Columbia River between Harrington Point and Bonneville Dam. The datum was established in 1911 by the U.S. Army Corps of Engineers and is described by Stolz and others (2005). Datum 'zero' is below average low water but is above the lowest recorded 
flows. CRD is maintained by the U.S. Army Corps of Engineers and is referenced to the Columbia River Mile* and the National Geodetic Vertical Datum of 1929.

*Although I use metric units for analyses and descriptions of Columbia River place-based processes, river miles are retained for describing the CRD and other river-length based analyses because river miles are shown on U.S. Geological Survey topographic maps and are the reference frame for $C R D$.

\section{Mapping methods}

The ecosystem complex and geomorphic catena levels of the Classification, as well as a supplemental cultural feature layer are based on interpretive mapping. These process regimes, landforms, and cultural features, respectively, were interpreted primarily from topography, supplemented with aerial photographs, land-cover classification, previously published maps, and field observations.

\section{Mapping Extent}

The spatial extent of the Classification is based on geologic floodplains (nonjurisdictional, hereafter "floodplain") and the estimated limit of tidal influence in the estuary and its tributaries. The floodplain is the surface that has accumulated sediment through overbank deposition during the Holocene epoch. The outer extent of a geologic floodplain is generally the base of the slope along the valley bottom margin. This is considered to be the extent of fluvial/tidal sediment deposition but is not necessarily the same as the extent of inundation by flood waters. Most features within the floodplain are considered to be formed during the Holocene. However, bedrock and pre-Holocene sedimentary deposits are mapped where they are surrounded by Holocene deposits or 
have been shaped by Holocene floods. The limits of the floodplain were derived from our interpretation of the extent of Holocene alluvial deposits based primarily on lidar topography in conjunction with existing geologic maps, historical flood elevations (U.S. Army Corps of Engineers, 1968), and the floodplain extent shown on U.S. Coast and Geodetic Survey T-sheets. The edges of the floodplain are obscured in places because of landslide deposits and anthropogenic modification. In some places, floodplain edges are indistinct, particularly where it abuts pre-Holocene alluvial deposits. Where the floodplain edge is obscured or indistinct, the map extent was based on the limit of historical flooding as shown in U.S. Army Corps of Engineers (1968) flood profiles and includes peripheral landforms, such as landslides, tributary fans, and terrace deposits (older alluvium). For some of the smaller landslides, a straight line was drawn across the landslide connecting the floodplain edges on the sides of the landslide. Where possible, lines were drawn based on breaks in slope, locally resulting in delineated floodplain extents that are either above or below the 1894 flood of record.

The up-valley extent of detailed mapping for tributary valleys is generally either the published limit of navigation defined by the U.S. Coast Guard (Exhibit 11-K-1), where the water surface of the channel is more than $3 \mathrm{~m}$ above NAVD88, where there was a convenient break (such as a tributary confluence or other change in valley character) shortly upstream of where the channel crossed the 3-m elevation. The elevation of $3 \mathrm{~m}$ is higher than mean higher high water at all tide stations along the Columbia River, though tides locally affect streamflow velocity and stage above the limit of detailed mapping. I assumed they have minimal effects on function or evolution of floodplain landforms. Tributary valleys were outlined beyond the limit of detailed 
mapping to include all areas below the influence of the 1894 Columbia River flood of record, except for the Cowlitz River, which was mapped in detail for the entire area below the maximum Columbia River stage of the 1894 flood.

\section{Geomorphic Catenae and Ecosystem Complexes}

Geomorphic catenae and ecosystem complexes were mapped simultaneously from the merged digital terrain model supplemented with other data. Columbia River Datum (CRD) was used to visualize topography above Columbia River Mile 22 (Harrington Point). Lidar topography was adjusted to CRD using river mile-based conversion factors from the U.S. Army Corps of Engineers (1978) and NOAA VDatum software (http://vdatum.noaa.gov/). Elevations were not adjusted downstream of Harrington Point where there is no conversion for CRD. Elevation was symbolized using a hypsometric tint over a range of 0 to $12.2 \mathrm{~m}$. For the Willamette and Cowlitz Rivers, whose floodplain elevations are higher than the Columbia River, tinting was adjusted to enable visualization of features to the estimated limits of tidal influence.

Floodplain landforms were primarily interpreted at a scale of 1:5,000 from 1-m resolution lidar-derived elevation, slope, and profile curvature grids (Figure 13). Landform features were outlined at scales ranging from 1:2,000 to 1:5,000. Features were classified based on their geometry, relation to other features, previously published geologic and soils maps, historical topographic maps, aerial photographs, and field observations. Although most features were outlined on the basis of slope breaks and relative elevation differences, some map units are not topographically distinct (such as some wetlands and lakes) and were delineated based on vegetation patterns, extent of water, or previously published maps. The outlined floodplain features were classified 
according to the type of landform (geomorphic catena, Tables 1-3), inferred process regime it is associated with (ecosystem complex, Table 4), and channel associated with the process regime.

Channel and backwater units were classified (by University of Washington) into deep, permanently flooded, and intermittently exposed areas based on elevation based rules. Parts of otherwise intermittently exposed areas were classified by visual interpretation of bathymetry as intermittently exposed bedrock or tributary delta deposits.

More detailed technical information on dataset creation is included in their metadata at http://water.usgs.gov/lookup/getspatial?creec_geomorphic_catena, http://water.usgs.gov/lookup/getspatial?creec_ecosystem_complex, http://water.usgs.gov/lookup/getspatial?creec_hydrogeomorphic_reach, and http://water.usgs.gov/lookup/getspatial?creec_cultural_features 

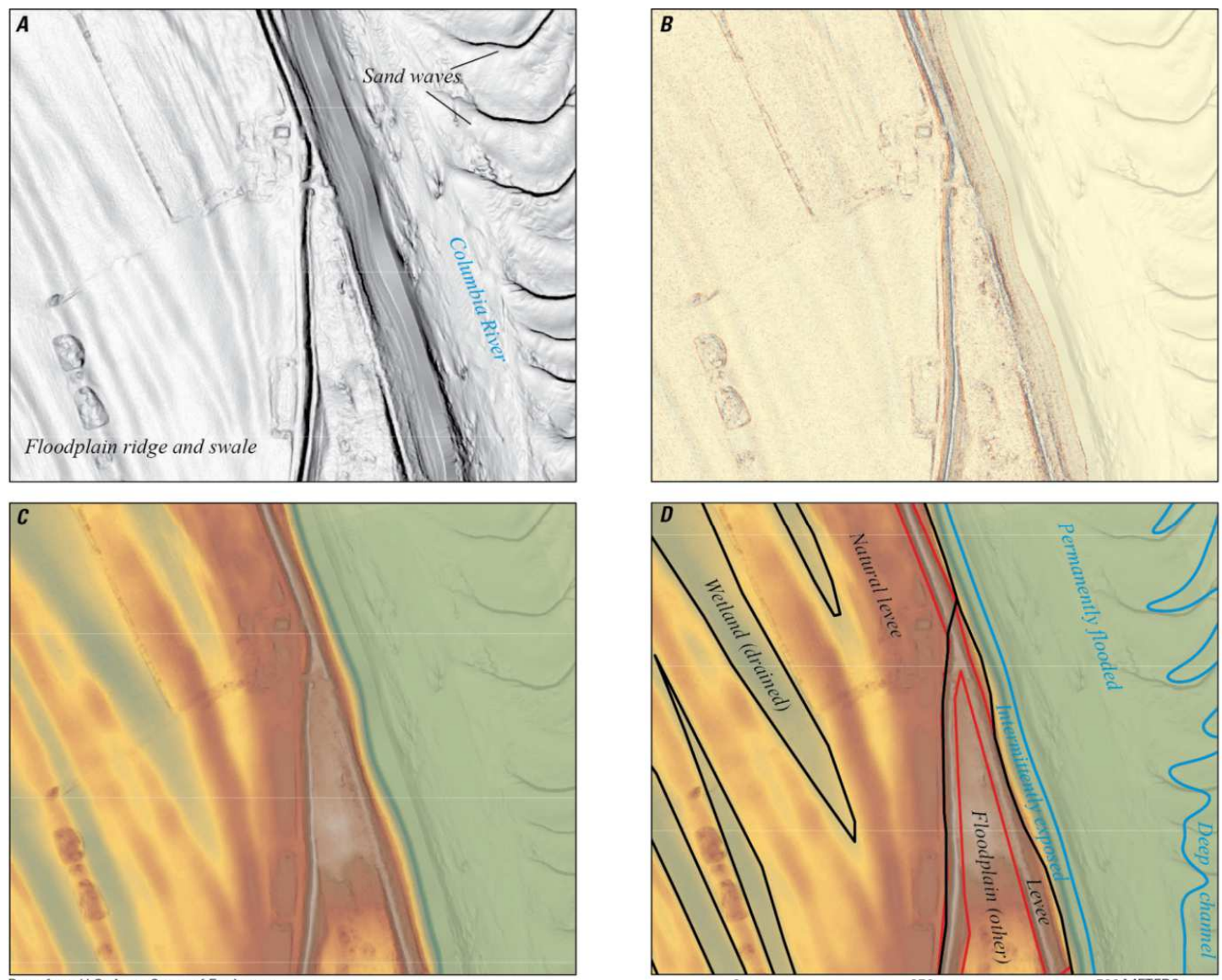

Base from U.S. Army Corps of Engineers 2010, 1-m resolution topography
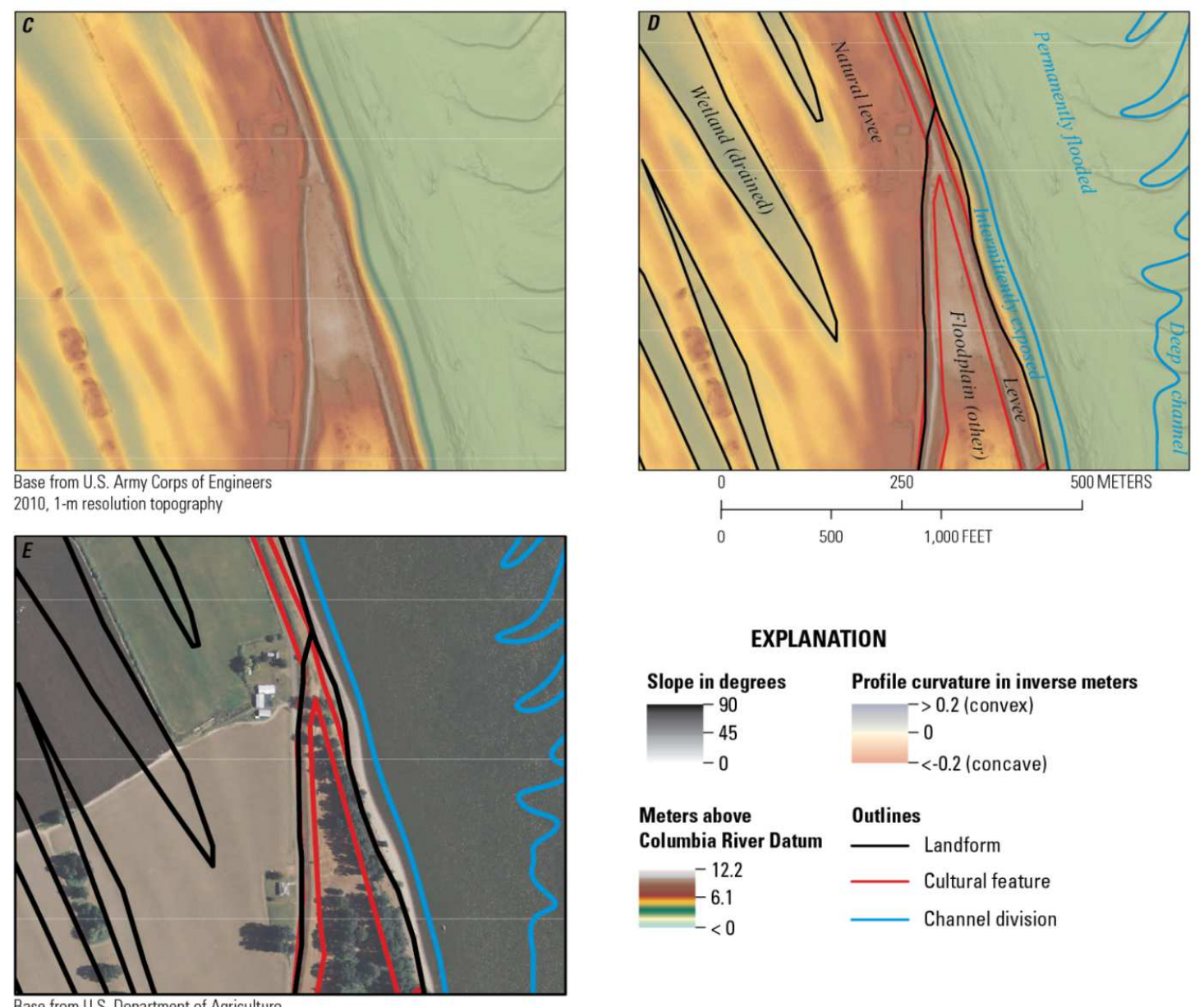

EXPLANATION

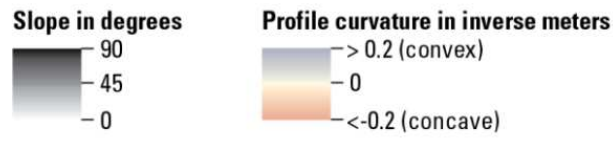

Meters above

Outlines

Columbia River Datum

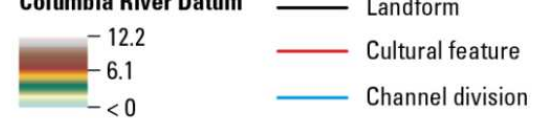

2009, 1-m resolution orthophotograph

Figure 13. Illustration of terrain visualization methodology used to map landforms showing A) slope, B) profile curvature, C) elevation above Columbia River Datum, D) mapping outlines, and E) aerial photograph for a locality near Willow Point, Oregon in Reach F. 
Table 1. Channel and backwater catenae descriptions; [Abbreviations: UW, University of Washington School of Aquatic and Fishery Sciences; NAVD88, North American Vertical Datum of 1988; MLLW, Mean Lower Low Water; CRD, Columbia River Datum; MHHW, Mean Higher High Water; NWI, National Wetlands Inventory]

\begin{tabular}{|c|c|c|c|}
\hline $\begin{array}{l}\text { Geomorphic } \\
\text { Catena }\end{array}$ & Definition & Mapping Criteria & Mapped by \\
\hline $\begin{array}{l}\text { Artificial } \\
\text { water body }\end{array}$ & $\begin{array}{l}\text { Artificial water body that is } \\
\text { not a lake or channel }\end{array}$ & & Cannon \\
\hline Channel bar & $\begin{array}{l}\text { Active accumulation of fluvial } \\
\text { sediment adjacent to or within } \\
\text { a channel }\end{array}$ & $\begin{array}{l}\text { Convex-up, bare to sparsely vegetated, } \\
\text { adjacent to or within channel, below } \\
\text { limit of annual flooding }\end{array}$ & Cannon \\
\hline Deep channel & $\begin{array}{l}\text { Channel below 20th percentile } \\
\text { of bathymetry }\end{array}$ & $\begin{array}{l}\text { Channel areas more than } 11.3,6.8,- \\
13.3 \text {, and } 6.9 \text { meters below NAVD } 88 \\
\text { for Columbia River Reaches A-F, } \\
\text { Columbia River Reaches G-H, } \\
\text { Willamette River, and Multnomah } \\
\text { Channel respectively }\end{array}$ & UW \\
\hline $\begin{array}{l}\text { Intermittently } \\
\text { exposed }\end{array}$ & $\begin{array}{l}\text { Area between low water and } \\
\text { the edge of channel }\end{array}$ & $\begin{array}{l}\text { Below MLLW or CRD for downstream } \\
\text { and upstream, respectively, of } \\
\text { Longview }\end{array}$ & UW \\
\hline $\begin{array}{l}\text { Intermittently } \\
\text { exposed } \\
\text { bedrock }\end{array}$ & $\begin{array}{l}\text { Bedrock outcrop within the } \\
\text { intermittently exposed active } \\
\text { channel }\end{array}$ & $\begin{array}{l}\text { Rough surface texture, depiction on } \\
\text { navigation charts, geologic maps }\end{array}$ & Cannon \\
\hline $\begin{array}{l}\text { Permanently } \\
\text { flooded }\end{array}$ & $\begin{array}{l}\text { Channel or backwater areas } \\
\text { between deep channel and } \\
\text { intermittently exposed }\end{array}$ & & UW \\
\hline Side channel & $\begin{array}{l}\text { Secondary channels along } \\
\text { tributaries }\end{array}$ & $\begin{array}{l}\text { Seasonally or perennially connected to } \\
\text { tributary channel at both ends }\end{array}$ & Cannon \\
\hline $\begin{array}{l}\text { Tributary } \\
\text { delta }\end{array}$ & $\begin{array}{l}\text { tributary deposit in } \\
\text { intermittently exposed channel }\end{array}$ & $\begin{array}{l}\text { proximity to tributary channel or } \\
\text { tributary fan }\end{array}$ & Cannon \\
\hline $\begin{array}{l}\text { Unknown } \\
\text { depth }\end{array}$ & $\begin{array}{l}\text { Channel or backwater areas } \\
\text { where no bathymetry data } \\
\text { were available to classify } \\
\text { further }\end{array}$ & & UW \\
\hline
\end{tabular}


Table 2. Surge plain geomorphic catenae descriptions; [Abbreviations: UW, University of Washington School of Aquatic and Fishery Sciences; NAVD88, North American Vertical Datum of 1988; MLLW, Mean Lower Low Water; CRD, Columbia River Datum; MHHW, Mean Higher High Water; NWI, National Wetlands Inventory]

\begin{tabular}{|c|c|c|c|}
\hline $\begin{array}{l}\text { Geomorphic } \\
\text { Catena }\end{array}$ & Definition & Mapping Criteria & Mapped by \\
\hline Lower flooded & $\begin{array}{l}\text { Lower part of active surge } \\
\text { plains }\end{array}$ & $\begin{array}{l}\text { Below MHHW, herbaceous } \\
\text { vegetation where not altered, high } \\
\text { density of narrow dendritic } \\
\text { channels, smoother surface than } \\
\text { upper flooded }\end{array}$ & Cannon \\
\hline $\begin{array}{l}\text { Tertiary } \\
\text { channel, } \\
\text { intermittently } \\
\text { exposed }\end{array}$ & $\begin{array}{l}\text { Intermittently exposed parts of } \\
\text { surge plains channels that } \\
\text { have both ends connected to } \\
\text { another channel }\end{array}$ & $\begin{array}{l}\text { Exposed sediment in aerial } \\
\text { photographs or lidar topography }\end{array}$ & Cannon/UW \\
\hline $\begin{array}{l}\text { Tertiary } \\
\text { channel, } \\
\text { permanently } \\
\text { flooded }\end{array}$ & $\begin{array}{l}\text { Permanently flooded parts of } \\
\text { surge plains channels that } \\
\text { have both ends connected to } \\
\text { another channel }\end{array}$ & $\begin{array}{l}\text { Lack of exposed sediment in aerial } \\
\text { photographs or lidar topography }\end{array}$ & Cannon/UW \\
\hline Tidal channel & $\begin{array}{l}\text { Channels dominated by tides } \\
\text { in the lower estuary }\end{array}$ & $\begin{array}{l}\text { Dendritic appearance in topography; } \\
\text { sudden increase in width for } \\
\text { channels originating as small } \\
\text { tributaries, not connected to a } \\
\text { channel at both ends unless small } \\
\text { tributary }\end{array}$ & Cannon \\
\hline $\begin{array}{l}\text { Undifferentiated } \\
\text { flooded }\end{array}$ & Undifferentiated surge plain & & Cannon \\
\hline Upper flooded & $\begin{array}{l}\text { Higher surface of active surge } \\
\text { plains }\end{array}$ & $\begin{array}{l}\text { Above MHHW, shrub or forest } \\
\text { vegetation where not altered, fewer } \\
\text { dendritic channels and rougher } \\
\text { surface than lower flooded }\end{array}$ & Cannon \\
\hline
\end{tabular}


Table 3. Floodplain and other geomorphic catenae descriptions; [Abbreviations: UW, University of Washington School of Aquatic and Fishery Sciences; NAVD88, North American Vertical Datum of 1988; MLLW, Mean Lower Low Water; CRD, Columbia River Datum; MHHW, Mean Higher High Water; NWI, National Wetlands Inventory]

\begin{tabular}{|c|c|c|c|}
\hline $\begin{array}{l}\text { Geomorphic } \\
\text { Catena }\end{array}$ & Definition & Mapping Criteria & Mapped by \\
\hline $\begin{array}{l}\text { Artificial } \\
\text { beach/bar }\end{array}$ & $\begin{array}{l}\text { Non dredge-material beach } \\
\text { resulting from anthropogenic } \\
\text { activity }\end{array}$ & $\begin{array}{l}\text { Lack of vegetation, adjacent to water, } \\
\text { but not part of channel }\end{array}$ & Cannon \\
\hline Bedrock & $\begin{array}{l}\text { Bedrock above surface of } \\
\text { floodplain }\end{array}$ & $\begin{array}{l}\text { Irregular topography, high elevation, } \\
\text { geologic maps, dark color in aerial } \\
\text { photos }\end{array}$ & Cannon \\
\hline $\begin{array}{l}\text { Developed } \\
\text { floodplain }\end{array}$ & $\begin{array}{l}\text { Areas where floodplain is } \\
\text { completely obscured by } \\
\text { development }\end{array}$ & $\begin{array}{l}\text { High or flat topography, widespread } \\
\text { changes from historical maps, cultural } \\
\text { use on topographic maps and aerial } \\
\text { photographs }\end{array}$ & Cannon \\
\hline $\begin{array}{l}\text { Dredge } \\
\text { material } \\
\text { disposal }\end{array}$ & $\begin{array}{l}\text { Dredge material disposal sites } \\
\text { that have not been noticably } \\
\text { re-worked since deposition }\end{array}$ & $\begin{array}{l}\text { Higher than adjacent topography and/or } \\
\text { historical floods, conical deposits, soils } \\
\text { mapped as "psamments" at suborder } \\
\text { level, bare high ground in aerial } \\
\text { photographs, active disposal in aerial } \\
\text { photographs, Scotch broom, land } \\
\text { accreted since early maps }\end{array}$ & Cannon \\
\hline Dune deposit & $\begin{array}{l}\text { Accumulations of wind- } \\
\text { deposited sediment }\end{array}$ & $\begin{array}{l}\text { Soils mapping as dune deposits, high } \\
\text { elevation, ridge geometry, field } \\
\text { observations of well sorted } \\
\text { homogenous fine sand, previously } \\
\text { published work }\end{array}$ & Cannon \\
\hline Filled areas & Filled in areas & $\begin{array}{l}\text { Association with infrastructure, water } \\
\text { on early maps, channel-crossing } \\
\text { relationship }\end{array}$ & Cannon \\
\hline Floodplain & $\begin{array}{l}\text { Generic floodplain, areas that } \\
\text { are not further classified }\end{array}$ & & Cannon \\
\hline $\begin{array}{l}\text { Floodplain } \\
\text { channel }\end{array}$ & $\begin{array}{l}\text { Channels that do not originate } \\
\text { outside the floodplain and are } \\
\text { not connected to a primary or } \\
\text { tributary channel at both ends }\end{array}$ & & Cannon \\
\hline Lake bed & $\begin{array}{l}\text { Areas that were historically } \\
\text { lakes and have been drained, } \\
\text { but not otherwise modified }\end{array}$ & $\begin{array}{l}\text { Concave-up topography, lakes on early } \\
\text { maps, association with drainage ditches, } \\
\text { hydric soils }\end{array}$ & Cannon \\
\hline Lake/pond & $\begin{array}{l}\text { Bodies of water occupying } \\
\text { depressions in the floodplain } \\
\text { surface }\end{array}$ & $\begin{array}{l}\text { Concave-up topography containing } \\
\text { water, water on topographic, soils, or } \\
\text { other maps, water in aerial photographs, } \\
\text { lack of shrub or forest vegetation }\end{array}$ & Cannon \\
\hline $\begin{array}{l}\text { Landslide } \\
\text { deposit }\end{array}$ & $\begin{array}{l}\text { Mass wasting deposits within } \\
\text { the Holocene floodplain }\end{array}$ & $\begin{array}{l}\text { Irregular topography, proximity to steep } \\
\text { slopes, up-slope scarp, landslide } \\
\text { inventories, geologic maps }\end{array}$ & Cannon \\
\hline
\end{tabular}


Table 3-continued

\begin{tabular}{|c|c|c|c|}
\hline Natural levee & Alluvial ridge & $\begin{array}{l}\text { Ridge geometry, high relative elevation, } \\
\text { commonly long, continuous, and } \\
\text { roughly parallel to a channel or channel } \\
\text { remnant, association with swales or } \\
\text { channel bends, commonly in pairs } \\
\text { separated by a channel or relict channel }\end{array}$ & Cannon \\
\hline Terrace & $\begin{array}{l}\text { Alluvial deposit that owes to a } \\
\text { pre-historic flow regime or } \\
\text { base level }\end{array}$ & $\begin{array}{l}\text { Geologic maps, soil maps, higher } \\
\text { elevation, convex-up, often broad } \\
\text { smooth surface, proximity to other old } \\
\text { alluvial or marine deposits }\end{array}$ & Cannon \\
\hline Tie channel & $\begin{array}{l}\text { Channel connecting floodplain } \\
\text { lakes to the main river channel }\end{array}$ & $\begin{array}{l}\text { Aerial photographs, topography, and } \\
\text { topographic maps }\end{array}$ & Cannon \\
\hline $\begin{array}{l}\text { Tributary } \\
\text { (minor) }\end{array}$ & $\begin{array}{l}\text { Small channels that originate } \\
\text { outside the floodplain }\end{array}$ & $\begin{array}{l}\text { Aerial photographs, topography, and } \\
\text { topographic maps }\end{array}$ & Cannon \\
\hline Tributary fan & Alluvial fans from tributaries & $\begin{array}{l}\text { Association with tributary channel, } \\
\text { proximity to valley wall, steep conical } \\
\text { geometry, higher relative elevation }\end{array}$ & Cannon \\
\hline $\begin{array}{l}\text { Tributary } \\
\text { valley }\end{array}$ & $\begin{array}{l}\text { Low parts of tributary valleys } \\
\text { that extend outside the } \\
\text { Holocene Columbia River } \\
\text { floodplain above tidal } \\
\text { influence }\end{array}$ & $\begin{array}{l}\text { Estimated limits of tides, historical } \\
\text { flood profiles, flat valley bottom }\end{array}$ & Cannon \\
\hline Unknown & $\begin{array}{l}\text { Insufficient information for } \\
\text { classification }\end{array}$ & & Cannon \\
\hline $\begin{array}{l}\text { Volcanogenic } \\
\text { delta }\end{array}$ & $\begin{array}{l}\text { Accumulation of volcanogenic } \\
\text { debris at mouths of rivers } \\
\text { whose drainage includes } \\
\text { slopes of active volcanoes }\end{array}$ & $\begin{array}{l}\text { Other studies, pumiceous alluvium, } \\
\text { confluence of river draining active } \\
\text { volcano, higher than modern tributary } \\
\text { or Columbia River deposits }\end{array}$ & Cannon \\
\hline $\begin{array}{l}\text { Volcanogenic } \\
\text { delta affected } \\
\text { by Columbia } \\
\text { River floods }\end{array}$ & $\begin{array}{l}\text { Volcanogenic debris deposit } \\
\text { that has been re-shaped by the } \\
\text { Columbia River }\end{array}$ & $\begin{array}{l}\text { Other studies, ridges, swales, or } \\
\text { channels oriented roughly parallel to } \\
\text { Columbia River, low parts of } \\
\text { volcanogenic delta }\end{array}$ & Cannon \\
\hline Wetland & $\begin{array}{l}\text { Seasonally wet (or historically } \\
\text { seasonally wet) areas that have } \\
\text { little or no tidal influence }\end{array}$ & $\begin{array}{l}\text { Hydric soils, NWI, topographic map } \\
\text { symbology, vegetation differences, } \\
\text { drainage ditches, concave-up or flat, } \\
\text { mix of vegetation and water in aerial } \\
\text { photographs or lidar returns, low } \\
\text { relative elevation }\end{array}$ & Cannon \\
\hline
\end{tabular}




\section{Table 4. Description of ecosystem complexes}

\begin{tabular}{|c|c|}
\hline Complex & Brief Description \\
\hline \multicolumn{2}{|r|}{ Channel and Backwater Complexes } \\
\hline Primary channel & Primary channel of the Columbia River \\
\hline Secondary channel & Channel that is connected to the Columbia at both ends \\
\hline Tributary secondary channel & Channel beginning in a tributary and ending in Columbia River \\
\hline Tributary channel & Larger river tributaries to the Columbia River \\
\hline Backwater embayment & $\begin{array}{l}\text { Non-channel water bodies connected to tributary or primary channel } \\
\text { at their lower end }\end{array}$ \\
\hline \multicolumn{2}{|r|}{ Surge Plain complexes } \\
\hline Surge plain & Low relief tidal areas that support vegetation \\
\hline Isolated surge plain & $\begin{array}{l}\text { Low relief areas formerly tidal areas that are disconnected from tidal } \\
\text { influence }\end{array}$ \\
\hline \multicolumn{2}{|r|}{ Floodplain complexes } \\
\hline $\begin{array}{l}\text { Floodplain backswamp } \\
\text { Floodplain ridge and swale }\end{array}$ & $\begin{array}{l}\text { Low concave floodplain areas behind the natural levee of a river } \\
\text { Areas of alternating ridges and swales }\end{array}$ \\
\hline Floodplain & Generic floodplain, areas that are not further classified \\
\hline Crevasse splay & Delta in floodplain lake or wetland \\
\hline \multicolumn{2}{|r|}{ Tributary complexes } \\
\hline Tributary fan & Alluvial fans from tributaries \\
\hline Tributary floodplain & $\begin{array}{l}\text { Floodplains of tributary valleys where not mapped in detail and } \\
\text { floodplains of minor tributaries where there are features of the minor } \\
\text { tributary within the floodplain of the Columbia River or its tributaries }\end{array}$ \\
\hline Volcanogenic delta & $\begin{array}{l}\text { Accumulation of volcanogenic material at mouths of rivers whose } \\
\text { drainage includes slopes of active volcanoes }\end{array}$ \\
\hline \multicolumn{2}{|r|}{ Anthropogenic Complexes } \\
\hline Developed & Completely obscured by development \\
\hline Dredge disposal area & Dredge material disposal sites \\
\hline \multicolumn{2}{|r|}{ Non-fluvial and Relict Complexes } \\
\hline Bedrock & Bedrock above surface of floodplain \\
\hline Dune & Area of wind-blown sediment deposits \\
\hline Outburst flood deposits & $\begin{array}{l}\text { Material deposited from the breaching of a large landslide dam and } \\
\text { associated rapid draining of its impounded lake }\end{array}$ \\
\hline Landslide & Mass wasting deposits within the Holocene floodplain \\
\hline Terrace & Alluvial deposit from pre-historic flow regime \\
\hline Unknown & Insufficient information for classification \\
\hline
\end{tabular}




\section{Cultural Features}

The supplemental cultural features layer of the Classification is an inventory of anthropogenic landforms within the floodplain (table 5). Most cultural features were mapped in a manner similar to geomorphic catenae and ecosystem complexes and were interpreted at a scale of 1:5,000 from the lidar-derived elevation, slope, and profile curvature grids. Exceptions are ditches, most of which were mapped as 10-m wide polygons and only adjusted where their extent conflicts with other mapped features. Landforms were outlined at scales ranging from 1:2,000 to 1:5,000 based on the lidar topography. Only cultural features that could be distinguished based on topography are mapped. Cultural features were classified based on their geometry, relation to other features, USGS 1:24,000 scale topographic maps, and aerial photographs.

Table 5. Brief description of cultural features.

\begin{tabular}{ll}
\hline Cultural class & Description \\
\hline Dam & Fill with a body of water on the up-slope side \\
Ditch & $\begin{array}{l}\text { Excavated linear channels, generally about ten meters wide, may be only } \\
\text { seasonally wet }\end{array}$ \\
Excavation/cut & $\begin{array}{l}\text { Areas that have been excavated, including road/railroad cuts } \\
\text { Fill }\end{array}$ \\
& $\begin{array}{l}\text { Undifferentiated fill, includes built-up industrial areas, dredge spoils, piles of } \\
\text { developed areas }\end{array}$ \\
Fish passage structure & Fish ladders \\
Jetty/Groin & Rock fill structure with water on most sides \\
Levee & Dikes and Levees \\
Navigation Lock & Locks for ship passage \\
Other water & Miscellaneous artificial water bodies \\
Railroad & Topography associated with railroads \\
Road fill & Topography associated with roads \\
Wastewater treatment & Wastewater treatment ponds, often elevated above floodplain \\
\hline
\end{tabular}




\section{Chapter 3: Description and Interpretation of Mapping}

Groupings of landforms were classified as ecosystem complexes based on the inferred process regime that formed them. I discuss geomorphic catenae within the ecosystem complexes where they are most relevant. Some geomorphic catenae, such as wetlands, are different depending on which ecosystem complex they are part of and are therefore discussed in multiple complexes. Where applicable, I discuss historical changes to specific ecosystem complexes and to the processes that formed them. Summary tables of the ecosystem complexes and distribution by reach are in Appendix A.

\section{Channel and Backwater Complexes}

Primary channel

The primary channel of the Columbia River is the most extensive ecosystem complex in the study area and occupies $33 \%$ of the Classification area, with more than half of its area being in Reaches A and B. The primary channel is classified into intermittently exposed, permanently flooded, and deep channel geomorphic catenae where bathymetry information was available. Locally, parts of intermittently exposed areas are classified as intermittently exposed bedrock or as tributary delta.

\section{Permanently flooded}

Permanently flooded refers to areas between deep channel and intermittently exposed geomorphic catenae and is the most extensive geomorphic by area both within the primary channel (60\%) and within the Classification (25\%). 
Deep channel

Deep channel is the third most extensive geomorphic catena by area and is mostly in the primary channel of the Columbia River where it corresponds to channel areas more than 11.3 or 6.8 meters below NAVD88 for reaches A-F, or G-H respectively. These maximum elevations were determined by classifying bathymetry measurements into five quantiles for the two sets of reaches and using the deepest $20-\%$ quantile.

Although the deepest part of the primary channel is now generally deeper and more continuous than the first channel surveys in the 1800s (H-sheets), there are fewer extremely deep areas. Historically deep areas below -30 m NAVD88 were historically at Tongue Point, Three Tree Point, Coffin Rock, upstream of Warrior Rock, and at Jim Crow Point. Small areas at Tongue Point and Coffin Rock were as deep as -50 m. All of these extreme deep areas are associated with bedrock points that protrude into the primary channel or in-channel bedrock. The deep hole at Coffin Rock contains the lowest elevation, $-46 \mathrm{~m}$, in the Classification. Most of the deepest channel bottoms have shoaled in since the late 1800s but are still below $-30 \mathrm{~m}$ at Coffin Rock, Tongue Point, and near Three Tree Point.

Intermittently exposed

The channel area between low water datum and the edge of vegetated or developed landforms is considered intermittently exposed. This category covers $14 \%$ of the primary channel area and consists mostly of tidal flats, un-vegetated beaches, and sand bars. Downstream of Longview, Washington, the lower limit is Mean Lower Low Water (1983-2001 tidal epoch), and upstream is Columbia River Datum. The upper limit 
is the edge of dense vegetation or development and in lidar topography generally corresponds to a distinct inflection point.

Tributary delta

Tributary deltas are less than one percent of the primary channel area. They are commonly intermittently exposed deposits within channel adjacent to tributary fans, but the largest area of tributary delta is the expanse of intermittently exposed material along the Sandy River volcanogenic delta. A similar, but smaller tributary delta deposit is at the mouth of the Kalama River. The sediment forming these, including debris flow and volcanogenic deposits comes mostly from the tributary and is typically coarser than the sandy bed material of the Columbia River.

Intermittently exposed bedrock

Intermittently exposed bedrock is less than one percent of the primary channel area. At bedrock channel areas, only the area interpreted to be intermittently exposed is mapped, although bedrock locally extends into the deeper channel. Intermittently exposed bedrock is part of the primary channel at Warrior Rock on Sauvie Island, Coffin Rock near Goble, Oregon, and Elder Rocks near Goble, Oregon. All of these localities are or were historically associated with the deepest channel areas. Submerged parts of Warrior Rock have complicated efforts to maintain a shipping channel since the 1870 s (Willingham, 1983; Carlson and others, 2011), and parts of this outcrop have been removed to accommodate channel navigation. 


\section{Secondary channel}

Secondary channels are connected to the Columbia River at both ends at least seasonally and consist mostly (70\%) of the permanently flooded and intermittently exposed (14\%) geomorphic catenae. Five \% of the area of secondary channels is classified as unknown depth because of insufficient bathymetric information. Parts of intermittently exposed secondary channels are classified as deep channel, tributary delta, channel bar, and artificial water body at the geomorphic catena level. All of the artificial water bodies mapped in the secondary channel complex are fish passage structures.

Secondary channels range from relatively narrow channels within expansive floodplains, such as Deer Island, Westport, and Bachelor Island, and sloughs, to wide river branches flowing around the large islands such as Hayden, Government, and Lady Island. There are likely multiple ways secondary channels form including channel migration, avulsion, floodplain incision during overbank flooding, progradation of crevasse splays, and accretion of islands from shoals or channel obstructions.

Secondary channels have locally been altered by tide gates and pilings for flood control and navigation purposes. Deer Island Slough and Westport Slough both have tide gates that have resulted in shoaling of the channels. Columbia Slough was historically a secondary channel but has mostly been isolated by flood control levees. Pile dikes commonly found near the upstream ends of secondary channels where they induce deposition and focus streamflow into the primary channel. Examples of pile dike installation to manipulate flow include Martin and Burke Sloughs, as recorded by Handbury (1891): 
"In 1889 a permeable dam was built across the upper end of Martin Slough, and also one at Burke Slough. It was estimated that about one-tenth of the low-water discharge of the river passed through these sloughs, which was largely instrumental in the formation of Martin Island Bar. It was found that these sloughs did not shoal up as fast as was anticipated and that a large quantity of water was still passing through them. To remedy this 366 cords of brush and 1,170 tons of rock were placed on the dam at Martin Slough; and 82 cords of brush and 85 tons of rock were placed in that at Burke Slough..."

Comparing historical and modern bathymetry along Burke and Martin Island Sloughs indicates that they have generally aggraded by about 1 to $2 \mathrm{~m}$. Other secondary channels that have aggraded since the earliest hydrography surveys include the PrairieClifton Channel system near Brownsmead, Oregon, and channels around Puget, Crims, Fisher, Cottonwood, Bachelor, Lady, and Reed islands. All of these channels have pile dikes and/or dredge material at their upstream ends except for at Lady and Reed islands. Two notable exceptions to the apparent trend of aggrading secondary channels are channels around Hayden and Government islands in Reach $\mathrm{H}$.

\section{Backwater embayment}

Backwater embayments are connected to the main channel at their lower end but have much less current. Backwater embayments are less than $0.5 \%$ of the study area and were classified into intermittently exposed and permanently flooded catenae where bathymetry information was available. Nearly one-half of the area of backwater embayments is in Reach F. Scappoose Bay is about one-quarter of the total area of 
backwater embayment mapped. About one-third of mapped backwater embayments are artificial and include boat basins (such as at Tomahawk Island) and alterations from aggregate mining (such as at Ross Island on the Willamette River).

\section{Tributary Channel}

Tributary channels occupy $3 \%$ of the study area and were mostly classified into permanently flooded (38 \%), intermittently exposed (21 \%), and deep channel (4 \%) depth-based catenae where bathymetry information was available. The tributary channel complex also includes intermittently exposed units that were mapped by visual interpretation including tributary delta deposits, channel bars, side channels, artificial waterbody, and intermittently exposed bedrock. About one-third of tributary channel area is not further classified. In the lower reaches (A-C), this class includes many more streams, including small tributaries that would have been classified as "tributary (minor)" in the upper reaches. This was done to enable mapping of the tidally influenced parts of all channels and their associated landforms. The lock system at Willamette Falls was excavated into bedrock and is the only artificial waterbody mapped in the tributary channel complex.

Deep Channel

The only Tributary Channel with mapped Deep Channel catenae is the Willamette River in Reach F, where there is about $1 \mathrm{~km}^{2}$ of mapped deep channel. These deep areas are where the channel bottom is below -13.3 m NAVD88 and generally correspond to where the channel is dredged for ship navigation. Comparison of historical bathymetric 
survey points with modern bathymetry in the Willamette River below Doane Point indicate that the channel now averages about $6 \mathrm{~m}$ deeper than it was in the early 1900s.

Although not mapped as such in the Classification, because of poor bathymetry quality, the bathymetry indicates much of the Willamette River above Portland is equivalent to deep channel. These apparent deep channel areas include parts of rocky sub-reaches near Willamette Falls and near Lake Oswego where the channel bottom is below $-30 \mathrm{~m}$ NAVD 88 . These low areas are the deepest channel in the estuary upstream of Coffin Rock near the Kalama River confluence and are likely a result of enhanced scour resulting from channel confinement by bedrock and in the case of the deep pool near Willamette Falls appear to be a submerged plunge pool.

Side channel

Side channels are secondary channels along channels other than the mainstem Columbia River and are almost exclusively (98\%) part of tributary channels. Side Channels commonly isolate channel bars, but along the Willamette River enclose floodplain and bedrock islands. In the lower tidal reaches, side channels also enclose surge plain islands.

Channel bar

Like side channels, channel bars are mostly a tributary channel landform. They are commonly near or above the limit of tidal influence and are part of a continuum of floodplain development where parts of channels accumulate sediment and eventually transition to floodplain landforms. Channel bars commonly form near channel bends and in time can become stabilized and support vegetation. Some channel bars are associated 
with channel meander point-bar deposition and could represent insipient floodplain ridge and swale complexes.

Intermittently exposed bedrock

Although not an aerially extensive unit, Intermittently Exposed Bedrock within and (unmapped) channel bedrock within the Tributary Channel complex are locally important, particularly for much of the Willamette River between Portland and Willamette Falls where associated with the deep channel areas previously described.

Tributary secondary channel

Tributary secondary channel is the designation for a channel beginning in a tributary and connected to a larger channel at the downstream end. This class was only used for Multnomah Channel, which was classified into intermittently exposed, intermittently exposed bedrock, permanently flooded, and deep channel catenae.

\section{Surge Plain Complexes}

\section{Surge Plain}

Surge plains are low-relief tidal wetlands flanking the lower Columbia River and its tributaries (Kunze, 1994). They are distinctive in that they generally contain sinuous dendritic channels. Surge plains were only mapped downstream of the Cowlitz River confluence and were divided into upper flooded and lower flooded catenae based on relative elevation, density of dendritic channels, surface texture in lidar topography, and vegetation differences. Lower flooded areas support dominantly herbaceous vegetation and are mostly below mean higher high water (MHHW); whereas upper flooded areas 
support dominantly forest and scrub-shrub vegetation and are mostly above MHHW. In places, there is a distinct slope break between the two units. Where it could not be determined whether part of a surge plain corresponds to the upper or lower flooded unit, it was designated as undifferentiated surge plain. Channels within surge plains were classified as tidal channel, permanently flooded tertiary channel, and intermittently exposed tertiary channels. Some mapped surge plains are probably only inundated during the most extreme high tide events. In tributary valleys, the upper limit of the upper flooded surge plains was drawn at a break in slope, where the floodplain above is steeper than the surge plain below and is interpreted as being the beginning of landforms dominated by fluvial processes. Areas that would historically have been surge plain but are artificially isolated from flooding are considered isolated surge plain and not included in this unit. Surge plains locally contain fill that is not inundated during tidal cycles.

Surge plains form by vertical accretion of sediment and organic matter, at a rate controlled by frequency and duration of flooding (hydroperiod), sediment concentration of water, and trapping efficiency (Friedrichs and Perry, 2001; Gunnell and others, 2013). Once tidal flats become stable, vegetation is established and enhances sediment trapping (Friedrichs and Perry, 2001; Gunnell and others, 2013). During overbank flow, suspended sediment concentration and grain size decrease with distance from channels, resulting in coarser subtly higher deposits closer to channels (Reed and others, 1999; Friedrichs and Perry, 2001). As surge plains aggrade, hydroperiod decreases and the rate of sediment accumulation decreases (Friedrichs and Perry, 2001). As clastic sediment accumulation from flooding decreases, organic material from local vegetation becomes an increasingly dominant component of surge plain growth (Friedrichs and Perry, 2001). 


\section{Upper Flooded}

Upper flooded surge plains are tidal wetlands whose surface is mostly above mean higher high water and contain dendritic tidal channels. They are $42 \%$ of the surge plain complex area. They consist mostly of fine to medium sand accumulated in the past 2,000 years that grades upward into clayey silt 'mud caps' about 2 to $4 \mathrm{~m}$ thick. The muddy cap accumulated within or slightly above the intertidal zone and represents marsh surface aggradation within the past 1000 years (Atwater, 1994; Takada and Atwater, 2004).

Most un-altered upper flooded surge plains support scrub-shrub or forest vegetation in contrast to lower flooded surge plains that support mostly herbaceous vegetation. Vegetation patterns on the earliest detailed maps of the estuary indicate a notably extensive band of forested upper surge plain extending from Westport, Oregon to Skamokawa, Washington, including the Oregon floodplain near Westport, Puget Island, and most of the floodplain between Cathlamet and Skamokawa (Burke, 2010). Most of this wooded surge plain has been isolated by levee systems.

\section{Lower Flooded}

Lower flooded surge plains are tidal wetlands that are mostly below mean higher high water, and generally contain a denser network of dendritic tidal channels than upper flooded surge plains. They are $30 \%$ of the surge plain complex. Most un-altered lower flooded surge plains support herbaceous vegetation.

Vegetation patterns on the earliest detailed maps of the estuary indicate that the isolated surge plains of the Chinook and Wallacut rivers were historically lower surge plains and particularly large areas of former lower surge plains are isolated along the 
reach extending from Longview, Washington to near Marshland, Oregon. The largest contiguous area of isolated former lower surge plain is between Marshland and Port Westward, Oregon (near Clatskanie). Although there are few non-isolated lower surge plains to compare with in this reach, the isolated surge plain areas are on average about 2 $\mathrm{m}$ lower than non-isolated lower surge plains. The isolated surge plain near Clatskanie is perhaps an extreme elevation difference, and elsewhere, the difference between isolated and non-isolated historical lower surge plain "marshes" is generally less than one meter.

Islands between Skamokawa and Tongue Point, with the exception of Karlson, Marsh, and Brush Islands, are the largest area of un-altered lower flooded surge plains. Lower flooded surge plains are in places a consequence of re-established tidal connection to isolated surge plains. Notable examples of re-connected lower flooded surge plains are at Svensen Island and along Gnat Creek.

Tidal Channel

Tidal channels are tidally influenced channels within surge plains. They are $8 \%$ of the surge plain ecosystem complex. Mapped tidal channels only include those presently functioning as tidal channels that are wider than 10 meters. Former channel tidal channel systems within isolated surge plains are mostly classified as floodplain channels. Tidal channels differ from Secondary and Tertiary channels, in that they have no upstream river connection.

Most tidal channels are dendritic, sinuous, and appear laterally stable. These channels likely inherited their courses from drainage patterns in underlying tidal flats similar to salt marshes described by Redfield (1972). The apparent lateral stability of most tidal channels is likely a result of vegetation and results in tidal channels being 
narrower and deeper than those on tidal flats (Friedrichs and Perry, 2001). Other channels categorized as tidal channels, such as Blind Slough, Warren Slough, and Coal Creek Slough, are much larger and less sinuous. These larger channels are associated with tributaries and likely evolved from them. Some of the larger tidal channels have locally been altered by dredging and possibly by log raft storage.

\section{Tertiary Channel}

Tertiary channels are tidally influenced channels that are connected at both ends to other channels. They are generally more sinuous than secondary channels, but not as sinuous as tidal channels, and usually divide surge plain islands into smaller islands. Tertiary channels were classified as intermittently exposed or permanently flooded based on their appearance in aerial photographs and lidar topography. Similar to tidal channels, tertiary channels have locally been isolated from tidal influence and are represented as floodplain channels in the isolated surge plain complex. Isolated former tertiary channels near Brownsmead, Oregon historically formed a series of floodplain islands.

\section{Isolated Surge Plain}

Isolated surge plains are former surge plains that have been disconnected from tidal influence but retain features with similar plan-view geometry (flat with dendritic channels) to active surge plains. Isolated surge plain covers $10 \%$ of the Classification are, making it the most extensive non-channel ecosystem complex. Most isolated surge plains have land-cover associated with agricultural use, are enclosed by flood-control levees, and have subsided. This map unit does not include large areas that have been resurfaced by development. 
Most (94\%) isolated surge plain area is mapped as wetlands. Most of these wetland areas are drained by extensive ditch networks, but some are occasionally inundated by runoff from adjacent slopes or seasonally high ground water levels. Most channels within isolated surge plains are former tidal or tertiary channels that are blocked by flood-control levees or tide gates and mapped as floodplain channel. Historically,

these isolated areas would have had a greater density of channels, but lack of inflow, purposeful infilling, and natural sedimentation have converted many of them into wetlands or indistinguishable features.

\section{Floodplain Complexes}

Floodplain backswamp

Floodplain backswamps, also known as “floodbasins” (Makaske, 2001) or “impeded floodplain” (Latrubesse and Franzinelli, 2002) are concave-up floodplain areas separated from channels by natural levees. They are $8 \%$ of the Classification area and are the third most extensive ecosystem complex. Backswamps are poorly drained and where unaltered consist of lakes or wetlands. Crevasse splays are associated with most floodplain backswamps. Mapped backswamps include both currently active (connected to estuary) backswamps as well as those that have been protected from flooding. Where protected from flooding, backswamps generally consist of lake beds and drained wetlands. Considerations in backswamp designation included presence of wetland soils, separation from the main channel by natural levees and association with crevasse splays. Backswamps and associated crevasse splays were historically dominant between the 
Sandy and Lewis River confluences and along the Willamette River downstream from Portland, but are now mostly between the Willamette and Lewis River confluences. Backswamps are parts of the floodplain where aggradation has lagged. In backswamp-dominated reaches, vertical accretion is concentrated on natural levees along channels and in crevasse splays. Growth of natural levees likely promotes sediment bypassing, particularly during times of high streamflow.

\section{Lake/pond}

Lakes or ponds are $32 \%$ of the floodplain backswamp complex and the largest area of lakes is in floodplain backswamps, mostly in Reach F. Sturgeon Lake is the largest lake in the Classification and most large lakes are in the Portland Basin between Portland International Airport and the Lewis River confluence.

Many of the larger lakes were historically connected to the Columbia River by at least one channel. These channels, part of the crevasse splay ecosystem complex, are mapped at the catena level as tie channels where still connected. Backswamp lakes are influenced by river stage, and where connected by tie channels, are influenced by tides, though tidal fluctuation in backswamp lakes is less than in the main channel. Klingeman (1987) describes Sturgeon Lake daily tidal fluctuations as generally less than $15 \mathrm{~cm}$ with a corresponding tidal range of $90 \mathrm{~cm}$ in Multnomah Channel.

Backswamp lakes and ponds have been affected by flood protection, draining, filling, and blockage of connecting channels. Connections between the Columbia River and almost all of the larger lakes are now partly or completely controlled, many by lakelevel regulating devices. Some lakes have been drained by ditches and pumps to create fields for agricultural use, especially on Sauvie Island. The $31 \mathrm{~km}^{2}$ of mapped lake bed is 
a minimum area of drained lakes since some former lakes are now in areas of developed floodplain and have been filled in, particularly in Reaches F and G near Portland (Figure 14). Blockage of tie channels at Sturgeon Lake has enhanced sedimentation, reducing its open-water area (Klingeman and others, 1982). Vancouver Lake has apparently also become shallower (Bhagat and Orsborn, 1971, U.S. Environmental Protection Agency, 1978).

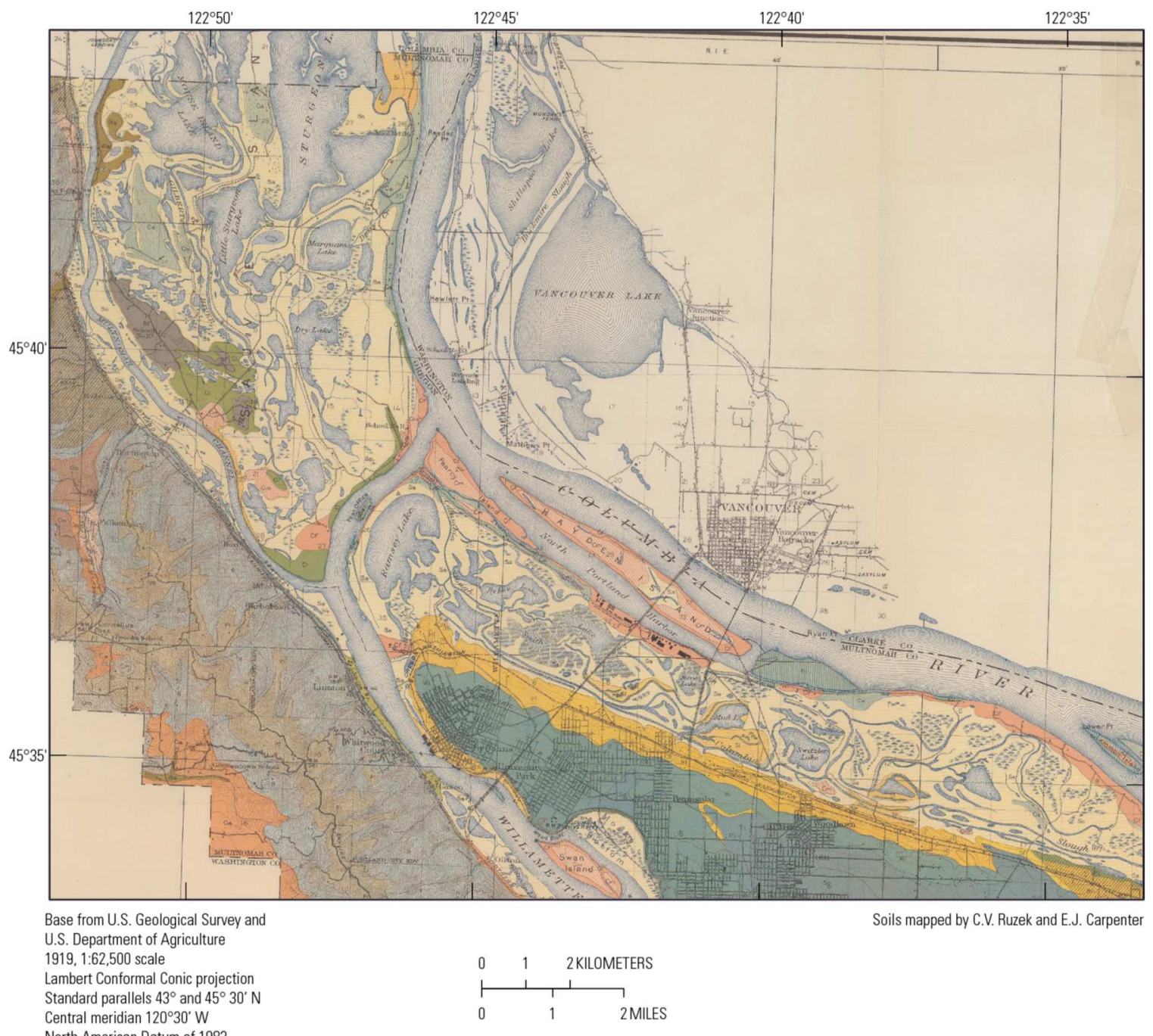

Figure 14. Part of U.S. Department of Agriculture soils map (Ruzek and Carpenter, 1919) showing floodplain lakes and wetlands near Portland, Oregon and Vancouver, Washington. 
Wetland

Thirtyone percent of floodplain backswamp area is mapped as wetland, mostly within the Portland Basin and near Rainier, Oregon. Backswamp wetlands are commonly on the outer edges of lakes and some are altered lakes. The distinction between lakes and wetlands is particularly uncertain in backswamp areas and some shallow lakes could probably be considered as wetlands. Similarly, some wetlands are seasonally inundated. Herbaceous wetlands adjacent to lakes are particularly prone to seasonal variability in interpretation. Forested wetlands are less prone to interpretive uncertainty from seasonal variability, because inundated vegetation is still visible in highest hit lidar returns and in aerial photographs. Drained lakes are common in backswamps and although they could be considered as wetlands, they are generally considered as "lake bed" in this Classification.

Lake bed

Nearly all mapped lake beds are within the floodplain backswamp complex, where they occupy $24 \%$ of the area. Lake beds are areas that were historically lakes and have been drained, but otherwise not significantly modified. A distinct feature of this unit as well as other drained wetland areas is the abundance of ditches they contain. Low relative elevation, abundant ditches, depiction of lakes on historical maps, and ground surface concavity were used to determine lake bed extents. NRCS soils mapping and field observations show that lake beds generally consist of silt loam or silty clay loam that is greatly reduced at depth (Figure 15). Most lakes beds are classified by NRCS as having hydric soils. Most are cultivated fields in aerial photographs and land cover classification is generally 'agriculture'. 
Lake beds are only mapped in Reaches F and G. Most (about $92 \%$ by area) are in Reach F and correspond to drained lakes at Sauvie Island, lowlands near Scappoose, Oregon, and Shillapoo Lake. Nearly one-third of the floodplain backswamp area in Reach F is classified as lake bed. Most of the mapped lake beds are shown as lakes, ponds, or wetlands on old USGS topographic maps, Coast and Geodetic Survey T-sheets, and General Land Office maps.

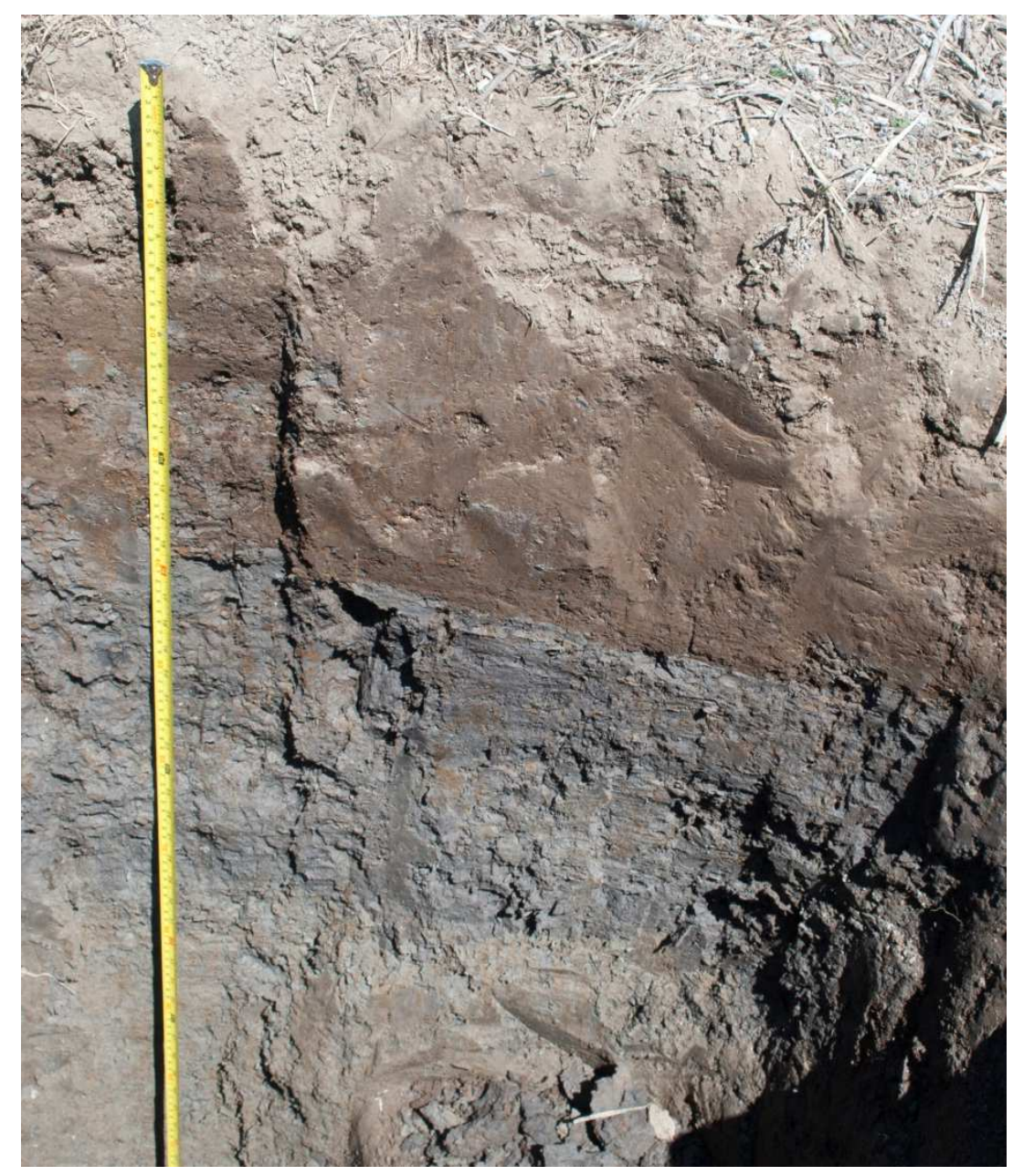

Figure 15. Excavation near edge of the lake bed of Little Sturgeon Lake (historical). Depth from surface to top of gley layer is $40 \mathrm{~cm}$. Photo C. Cannon, July 28, 2011 


\section{Floodplain Ridge and Swale}

Floodplain ridge and swale is the classification assigned to areas of sub-parallel

ridges ('natural levees') alternating with swales that often contain or would historically have contained wetlands or lakes. These areas represent lateral channel migration and often have somewhat crescentic appearance in plan view because they generally form along meander bends. Most floodplain ridge and swale areas are along the Columbia River between the Willamette and Cowlitz River confluences, but ridge and swale topography is also found along tributaries and locally along floodplain channels.

Natural levee

Natural levees are alluvial ridges along past or present channels and are $71 \%$ of the area of the floodplain ridge and swale complex. Natural levees form where streams flood and deposit the coarsest fraction of their sediment load and are generally the highest fluvial landforms within the floodplain, particularly the ridge and swale areas in Portland Basin Reaches E-G.

Wetland

Wetlands are common in the swales between floodplain ridges and occupy $15 \%$ of the complex area. Most ridge and swale wetlands are in Reaches E and F. In reaches E and $\mathrm{F}$, the distinction between ridge and swale lakes and wetlands is in some places ambiguous, and many are shown as lakes on T-sheets.

Floodplain

A classification of generic 'floodplain' was used for areas where sets of landforms were not further classified. About one-half (54\%) of the generic 'floodplain' complex is 
also generic 'floodplain' at the geomorphic level of classification. Classification as 'floodplain' at both geomorphic catena and ecosystem levels is common for areas where topography has been greatly obscured, but not completely re-surfaced by human activity. An example is upstream of Portland International Airport, where the floodplain was historically a floodplain backswamp, with numerous natural levees and elongated marshes roughly parallel to the Columbia River. The marshes have mostly been filled in and most natural levees have been obscured to the point that it is nearly impossible to discriminate their outer edges. The main channels of the Columbia Slough system are still present, but have been altered by street crossings and flood-control levees and their flow is regulated by pumping.

Another common use of the 'floodplain' complex is for natural levees along laterally stable non-crevasse-splay channels. Examples include the broad natural levees along parts of the Columbia River and natural levees along active and abandoned secondary channels.

\section{Crevasse splay}

Crevasse splays are delta-like deposits generally consisting of a pair of natural levees bounding a channel or channel remnant that intrude into a backswamp or other low floodplain area. Active crevasse splays consist of two natural levees perpendicular to a larger channel and are separated by a channel (Figure 16). Where a crevasse splay channel connects a floodplain lake to the main river channel, the channel is classified as a tie channel at the geomorphic catena level. For crevasse splays that are no longer active, the channel generally transitions to a wetland and eventually undifferentiated floodplain. Where crevasse splays have degraded enough that natural levees are no longer 
distinguishable, the entire crevasse splay was mapped as floodplain at the catena level. Most (80 \%) crevasse splays are in Reach F and are associated with floodplain backswamp areas. Between the Cowlitz and Clatskanie River confluences, the distinction between crevasse splays and tidal channels is in places ambiguous. Most features mapped as crevasse splays in this sub-reach are less sinuous than tidal channels and have more distinct natural levees but bifurcate more than crevasse splays mapped upstream. Most crevasse splays in the transitional reach are not shown as being connected to the primary channel on T-sheets.

Crevasse splays in the Classification may correspond to the tie channels of Rowland and others (2009), the classical crevasse splays of Smith and others (1989), or some of both. The tie channel model of crevasse splay evolution would imply that a connection is maintained between the main channel and backswamp lakes. As the natural levee along the main channel aggrades, the narrow connection between river and lake causes a sediment laden jet to develop, depositing levees along its margins that can continue to aggrade to the height of the main river channel levees (Rowland and others, 2009). The levees further concentrate flow, enabling the channel and its levees to extend farther into the lake. Crevasse splays in the Portland Basin are morphologically similar to tie channels of Rowland and others (2009) in that they are laterally stable, rarely bifurcate, convey bi-directional flow, and coincide with lakes or former lakes. Rowland and others (2009) suggest that tie channel type crevasse splays may maintain a stable connection to the mainstem for hundreds to thousands of years, and generally only convey suspended load. 
Tie channel type crevasse splays differ from classical definitions (for example, Smith and others, 1989; Neuendorf and others, 2005) where crevasse splays are low energy lacustrine deltas that form when a natural levee is breached during floods. Smith and others (1989) describe a 3-stage progression of crevasse splay evolution where 1) sediment is deposited by sheet flow after a levee breach; 2) a network of anabranching distributary channels evolves, forming a splay complex with focused flow and sediment transport; and 3) the splay progrades into the basin, becoming increasingly elongated with less pronounced anabranching patterns and sometimes forming a mouth bar. Stages 1 and 2 of Smith and others (1989) are not necessarily flow into a waterbody and primarily involve bedload transport. Stage 3 crevasse splays are generally prograding into lakes and sediment transport is primarily by suspended load, similar to tie channel type crevasse splays. It is possible for stage 3 crevasse splays to form without evolving from a Stage I or II splay, if there is standing water in the flood-basin it invades (Smith and Perez-Arlucea, 1994).

Most larger tie-channel type crevasse splays point upstream relative to Columbia River flow and are longer than crevasse splays whose connection is perpendicular to the main channel. Where not behind flood control levees, water in these tie channels is tidally influenced. Crevasse splays that are roughly perpendicular to the mainstem are generally smaller, and most do not have active tie channels. One possible set of explanations for the apparent two populations of crevasse splays is that 1) tides help maintain connections for upstream-pointing crevasse splays; and 2) perpendicular-connected splays are easily blocked by bedload deposits and other debris, such as large wood, and are only active during large floods. Tides as a cause of the two populations of crevasse splays is 
consistent with the general lack of long upstream pointing crevasse splays in non-tidal backswamp-dominated reaches of other rivers such as the upper Columbia (Rocky Mountain Trench reaches), Kamchatka, and Amazon Rivers.

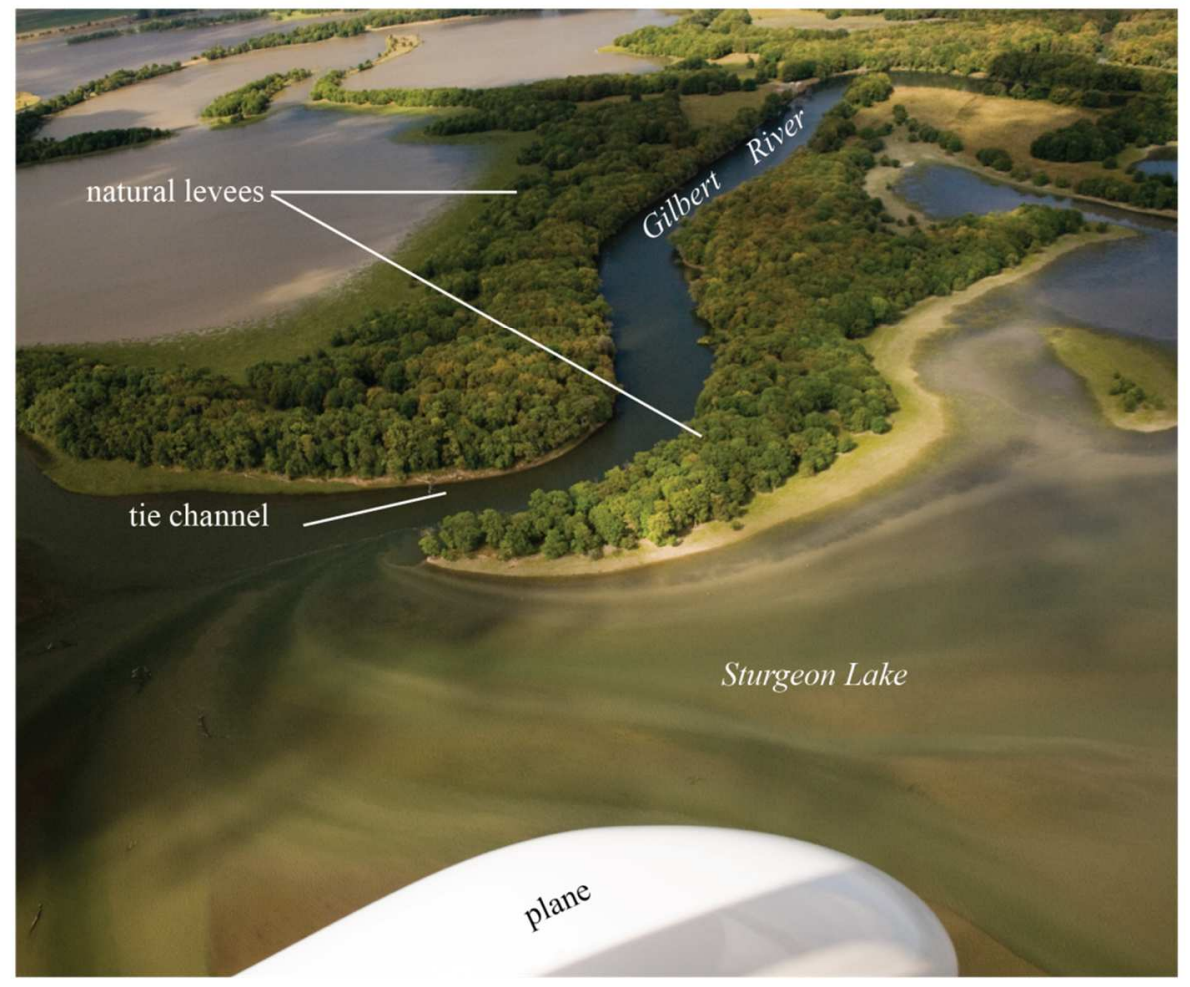

Figure 16. Sturgeon Lake, Oregon showing Gilbert River crevasse splay features (natural levees and tie channel). Photo by C. Cannon, 2013, with aerial support from Lighthawk Aviation

\section{Tributary Complexes}

Tributary fan

Tributary fans are accumulations of alluvium that form where steeper tributary streams enter the relatively flat floodplain of the Columbia River or its tributaries.

Tributary fans are generally associated with minor tributary streams. The fans of most small tributaries are semi-conical in plan view and roughly symmetric about an apex at 
the mouth of the stream valley, but some such as at Scappoose and Gee creeks are deltalike deposits. Although most tributary fans mapped are within the Columbia River floodplain, there are some that extend outside the floodplain. A notable example that extends outside the floodplain is the large fan complex near Dodson, Oregon. In general, tributary fans consist of tributary fan and minor tributary channels at the catena level of the classification. Commonly, the tributary channel is too small to be mapped. There are also places where there are wetlands or lakes included within the tributary fan complex. Where floodplain channels are included it is because floodplain channels are classified as part of the complex they flow through.

\section{Tributary floodplain}

Tributary floodplain mostly corresponds to floodplains of tributary valleys where not mapped in detail, but was also used for where minor tributaries have features other than a channel within the floodplain of the Columbia River or its tributaries.

\section{Volcanogenic delta}

Volcanogenic deltas are accumulations of volcanogenic debris at mouths of rivers draining the slopes Mount Hood and Mount Saint Helens. Volcanogenic deltas are composed of deposits associated with channel aggradation and delta progradation caused by influx of sediment to their corresponding river systems during and after eruptions (Rapp, 2005; Vogel, 2005; Evarts and O’Connor, 2008). Most volcanogenic delta is not further differentiated at the geomorphic catena level, but locally can contain lakes, wetlands, and channels. Where notably re-worked by the Columbia River, it is classified as 'volcanogenic delta affected by Columbia River floods' at the geomorphic catena level 
of the Classification. The four volcanogenic deltas mapped are at the mouths of the Sandy, Lewis, Kalama, and Cowlitz rivers.

\section{Anthropogenic Complexes}

\section{Developed}

Areas where floodplain is completely obscured and/or re-surfaced by human activities are mapped as 'developed'. Most developed floodplain corresponds to port, industrial, and urban areas. Most of the developed complex is considered developed floodplain at the catena level, but locally includes artificial or altered water bodies and wetlands. In places, filled areas are separated out based on water bodies shown on Tsheets or old aerial photographs, but many smaller filled in areas are included within the developed floodplain catena classification. Many developed areas probably consist largely of dredged material, but are only mapped as dredge disposal where they have not been re-worked into port, industrial, urban, or other cultural uses. The largest developed areas correspond to the Portland/Vancouver metropolitan area and Longview/Kelso, Washington.

\section{Dredge Disposal Area}

Dredge disposal areas are only mapped where they have not been significantly reworked by fluvial or other processes. Dredge disposal areas are mapped as such at both the ecosystem complex and geomorphic catena levels of the Classification. Dredged material deposits are generally distinctive in that they have a higher maximum elevation than adjacent floodplain landforms and often have a conical geometry. Dredge disposal areas are commonly represented in NRCS soils mapping as psamments at the suborder 
level. More recent deposits could be identified by textural differences in aerial photographs. Dredge disposal areas are commonly land that has been accreted since the original coast and geodetic surveys (T-sheets) and are mapped in all reaches except Reach H. Most dredge disposal areas are in Reaches D, C, and B.

Dredging by the U.S. Army Corps of Engineers to maintain a navigation channel between Portland and the Columbia River began on the Lower Willamette River in 1867 and on the Columbia River in 1873 with the removal of Saint Helens Bar near Saint Helens, Oregon (Willingham, 1983).

Most dredge disposal areas are from navigation channel dredging, but about $29 \%$ of the total mapped dredge disposal area is in Reach D along the Cowlitz River and between the Kalama and Cowlitz River confluences along the Columbia River. These deposits in Reach D are from emergency dredging carried out by the U.S. Army Corps of engineers re-open the Columbia River shipping channel, and to protect cities along the lower Cowlitz River from flood risk following the 1980 eruption of Mount St. Helens (Figure 17, Willingham, 2005). 


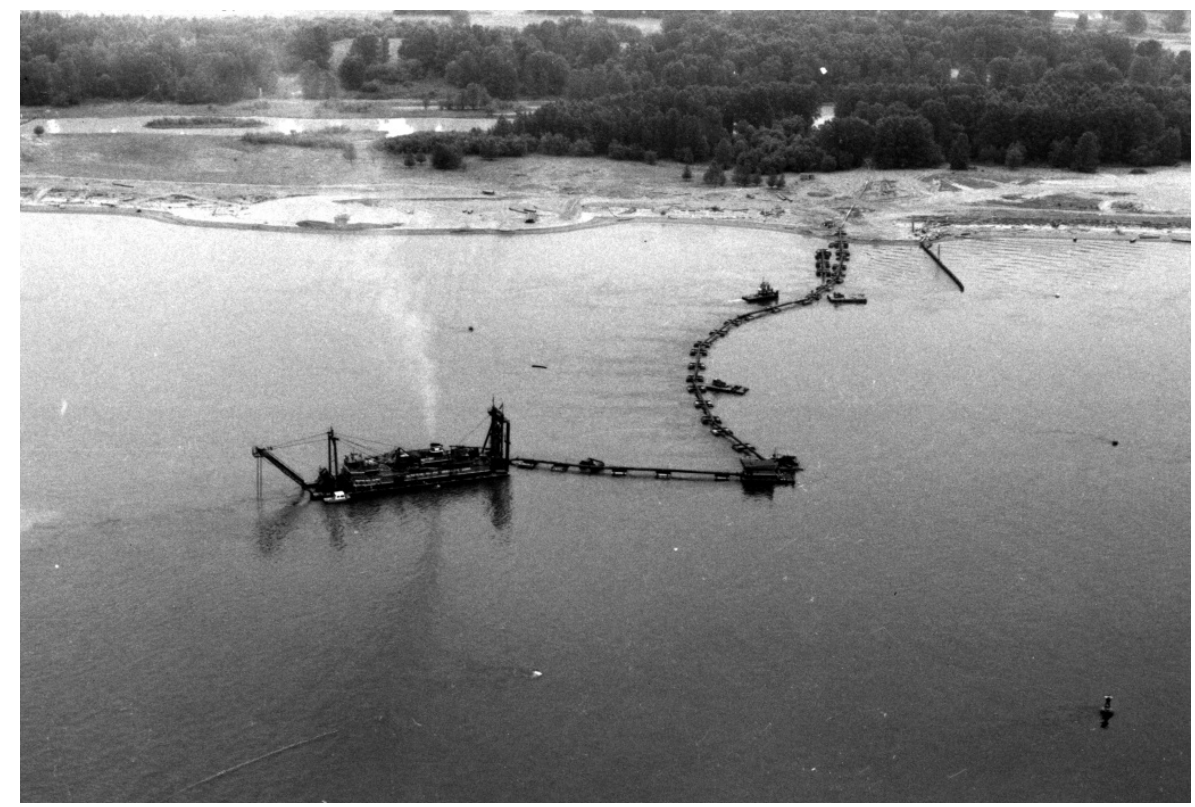

Figure 17. Dredging near Longview, Washington in response to Mount St. Helens eruption. Material is removed from the river bottom, transported through a pipeline, and deposited on land. U.S. Geological Survey photo taken by R. Schuster on July 10, 1980.

\section{Non-fluvial, Relict, or Pre-Holocene complexes}

\section{Bedrock}

Bedrock features were mapped within the floodplain extent in all reaches.

Classification as bedrock does not necessarily imply that bedrock is visible, and includes bedrock cored features with a topographic expression. Bedrock typically has irregular geometry in map view. Larger bedrock areas are shown on geologic maps. In Reach F, particularly along the Willamette River, previous geologic mapping (For example, Ma and others, 2009) was used to identify bedrock that was not evident based solely on topography. Aerial photographs were also used to identify bedrock where it crops out. Generally the only geomorphic catena within the bedrock complex is bedrock, but locally there are depressions or excavations in the bedrock that contain lakes or wetlands. There are some lakes within the bedrock complex that represent either excavations in bedrock 
(such as near Mount Solo, Washington) or indentations in bedrock (such as near Gee Creek, Washington).

Dune

Dunes in the Classification are accumulations of wind-deposited sediment. All of the dune deposits in the Classification probably accumulated during the Holocene. The dune complex consists mostly of dunes, but in larger dune areas, such as near the mouth of the Columbia River, also includes lakes and wetlands between dune ridges where drainage has been blocked by sand or where deflation has occurred. Classification as dune deposits was based on geometry, NRCS soils mapping, and field observations.

\section{Marine Influenced Dunes}

Dune complexes of the Clatsop Plains and along Baker Bay are influenced by marine processes including sediment transport by wind, waves, and littoral drift. The Clatsop Plains dune complex is part of a littoral cell whose primary source of sediment is the Columbia River. The Clatsop Plains are a series of subparallel dune ridges and swales that have formed since about $5 \mathrm{ka}$ (Reckendorf and others, 2001) as the shoreline has prograded westward.

Construction of Columbia River jetties began in 1885, pushing the ebb-tide delta offshore and supplying sand to adjacent shore areas (Byrnes and Li, 2001). Clatsop Spit near the south jetty has prograded about $4.5 \mathrm{~km}$ since the beginning of Jetty construction. Clatsop Spit accumulated $7 \mathrm{~km}^{2}$ of new land between 1868 and 1926. Since the 1950s, progradation throughout the littoral cell has generally slowed and locally erosion has occurred, such as at Clatsop Spit adjacent to the south jetty (Kaminsky and others, 2010). 
Vegetated dunes flank the emergent surge plains along Baker Bay. The Baker Bay dunes were historically active and are likely a result of southerly shore-parallel winds entraining intermittently exposed sediment from Baker Bay. The Baker Bay shoreline would historically have been influenced by southwest-approaching winter waves and was likely an environment similar to ocean beaches. The construction of the jetty system as well as northwest migration of Clatsop Spit and the Sand Islands has made Baker Bay more protected, likely enabling the emergent surge plain to support vegetation and ceasing sediment transport to the dunes.

\section{Portland Basin Dunes}

About one-quarter of dune area is in Reach F, including three distinct uplands on Sauvie Island. The dunes on Sauvie Island have not been historically active and have probably been stable for thousands of years. The dunes are locally higher than the 1894 flood of record. Presence of a Bw soil horizon in the Sauvie Island dunes implies that the dunes may have been stable for thousands of years.

NRCS soils maps mostly show the Sauvie Island dunes as the Burlington soil series, which is described by Ruzek and Carpenter (1922) as:

"fine sand of wind-blown origin, the material coming from sand deposits laid down by the Columbia River along its banks. The material was originally derived from a variety of rocks, principally quartz bearing, though mingled with it is some basaltic sand".

Another area of mapped dunes in Reach F is at the upstream end of Vancouver Lake, where a few broad sand ridges are higher than most historical floods, but would be 
covered by at least three meters of water in the flood of 1894. Although mapped as a dune, this designation is uncertain and it could possibly consist at least partly of Missoula flood deposits. Smaller irregularly shaped hills near the apparent dune ridge are also interpreted as dunes.

\section{Columbia Gorge Dunes}

Dunes near the west end of the Columbia River Gorge formed within the past $2 \mathrm{ka}$ (Rapp and others, 2002; Rapp, 2005) and some have historically been active. The dunes likely formed near water's edge from strong easterly winds entraining beach sand during winter low flow periods that were common before flow regulation.

Most of these dunes are now vegetated and are mostly inactive, at least in part because of the lower frequency of low winter flows in the modern regulated flow regime. These dunes coincide with the largest expanse of intermittently exposed channel upstream of Cathlamet, Washington in reach B, and are at the west end of the Columbia Gorge wind gap where strong winter easterly winds reach their highest velocities (Sharp and Mass, 2004). Velocities are highest in winter (November through February). Median streamflow for these months at The Dalles has increased and in warm phases of the Pacific Decadal Oscillation is about twice as great as pre-regulation flow (Figure 4). These higher flows result in a smaller area of exposed sediment that is available for transport by wind.

Outburst flood deposits

Outburst flood deposits are only mapped in the eight kilometers downstream of the Bonneville Landslide complex and are interpreted as deposits from breaching of the 
landslide dam and catastrophic lowering of the lake ("Lake of the Gods") impounded behind the dam. Outburst flood deposits are mapped based on higher elevation relative to most floodplain landforms, proximity to the Bonneville landslide, and field observations (Jim O'Connor, U.S. Geological Survey, unpublished). The "Lake of the Gods" flood (O'Connor, 2004) deposit age is constrained by deposits in the downstream reaches that underlie Mount St. Helens Kalama-age (A.D 1479 or 1482) tephra and the age of the Bonneville landslide inferred from tree mortality in the lake impounded by the landslide (A.D. 1425 and 1450; O'Connor and Burns, 2009) . Near Bonneville Dam, these deposits have been considerably altered by dam construction activities.

\section{Landslide}

Landslide deposits flank much of the Columbia River valley and are in places mapped where they are inferred to overlie Holocene alluvium or have been affected by Holocene floods. Landslide deposits were mapped in all Reaches except Reach G. Identification of landslides was based on upslope topography, which typically consists of scarps, landslide scars (hollows), or other irregular terrain. Geologic maps and statewide compilations of previously mapped landslides for Oregon and Washington were used as aids to identify landslides. Most of the mapped landslide areas consist solely of landslide deposits at the catena level, but locally include wetlands and lakes that have developed in the landslide deposit. Where landslide material obscures the edge of Holocene floodplain material, the landslide extent mapped was either a straight line connecting the floodplain margin on either side of the landslide deposit or the approximate elevation of the 1894 flood of record. Debris flow deposits are not included in the landslide deposit mapping unit, but are instead included in the tributary fan unit. 
Terrace

Terraces in the context of the Classification are alluvial deposits that owe to a prehistoric flow regime. Terrace deposits were mapped if they are either surrounded by the Holocene floodplain or have been apparently re-shaped by Holocene floods. Low parts of broad terraces flanking the mapped floodplain were mapped where they are below the limits of historical flooding. Most terraces mapped are interpreted to be Pleistocene or older fluvial deposits.

\section{Cultural features}

Mapped cultural features cover about $11 \%\left(174 \mathrm{~km}^{2}\right)$ of the Classification area. About $70 \%\left(122 \mathrm{~km}^{2}\right)$ of cultural feature area is undifferentiated fill. Fill for roads, levees, and railroads are 11,8 , and $3 \%\left(20,13\right.$, and $\left.0.5 \mathrm{~km}^{2}\right)$ of the cultural features respectively. Excavations for ditches cover about $5 \%\left(9.5 \mathrm{~km}^{2}\right)$ of the area of mapped cultural features and undifferentiated excavations cover about $1.2 \%\left(2.2 \mathrm{~km}^{2}\right)$ of the area of cultural features. Wastewater treatment, jetty/groin, other water, dam, navigation lock, and fish passage structure classifications were all less than one $\%$ of the area of mapped cultural features.

The largest areas of undifferentiated fill are in reaches $F$ and $G\left(35\right.$ and $28 \mathrm{~km}^{2}$ respectively) where most fill is associated with urban and industrial development in the Portland-Vancouver Metropolitan area. The reach with the greatest areal proportion of fill is Reach D, where $25 \%\left(24 \mathrm{~km}^{2}\right)$ of the reach area is fill. The fill in Reach D is largely the Longview, Washington industrial area and dredge disposal associated with the A.D. 1980 eruption of Mount St. Helens. Most fill areas in Reaches B and C (71 and 54 \%; 5.1 and $5.7 \mathrm{~km}^{2}$ ) are deposits from dredge disposal. Fill areas in Reach A are mostly 
associated with urban development at Astoria and Warrenton, including about $1 \mathrm{~km}^{2}$ of filled in Primary Channel at Astoria. Reach H has less undifferentiated fill by area than any other reach, nearly all of which is near Bonneville Dam.

Road fill is present in all reaches. The largest areas of road fill are in Reaches G, $\mathrm{D}$, and $\mathrm{A}\left(3.6,3.2\right.$, and $2.9 \mathrm{~km}^{2}$ respectively) and the reaches with the largest areal proportion that is road fill are Reaches $\mathrm{D}, \mathrm{H}$, and $\mathrm{G}$ with 3,3 , and $2.1 \%(3.2,1.9$, and 3.6 $\mathrm{km}^{2}$ respectively).

Levees are present in all reaches except Reach $\mathrm{H}$. The largest areas of levee are in Reaches $\mathrm{C}, \mathrm{F}$, and $\mathrm{B}\left(4.1,3.2\right.$, and $\left.1.8 \mathrm{~km}^{2}\right)$ respectively and the reaches with the largest areal proportion that is levee are Reaches C, E, and F with 2, 1, and $1 \%(4.1,1.2,3.2$ $\mathrm{km}^{2}$ respectively). Most levees in reaches A, B, and C enclose isolated surge plains. In Reach D, most $\left(58 \% ; 0.5 \mathrm{~km}^{2}\right)$ levees enclose the altered floodplains of the Cowlitz and Coweeman Rivers, but levees also enclose the volcanogenic delta and developed floodplain of Longview, Washington. Most $\left(53 \% ; 0.6 \mathrm{~km}^{2}\right)$ of the mapped levee area in Reach $\mathrm{E}$ is on the Lewis River volcanogenic delta. Levees in Reach F generally enclose floodplain backswamp, floodplain ridge and swale, or dune areas. Most $\left(66 \% ; 2 \mathrm{~km}^{2}\right)$ Reach F levees are constructed on natural levees, commonly in floodplain ridge and swale areas or on the broad channel-flanking natural levees in the generic 'floodplain' ecosystem complex. Most mapped levee area $\left(74 \% ; 0.8 \mathrm{~km}^{2}\right)$ in Reach $\mathrm{G}$ encloses the altered floodplain and volcanogenic delta between Portland International Airport and the Sandy River.

Ditches are present in all reaches except Reach $\mathrm{H}$. The largest areas of ditch are in Reaches $\mathrm{C}, \mathrm{A}$, and $\mathrm{F}\left(3.3,1.6\right.$, and $\left.1.4 \mathrm{~km}^{2}\right)$ respectively and the reaches with the largest 
areal proportion that is ditch are Reaches $\mathrm{C}$, D, and A with 1.7, 0.7, and $0.6 \%(3.3,0.7$, and 1.6 ha) respectively. Ditches are mostly in floodplains that are or were formerly protected from flooding by levees. In Reaches A, B, and C, most ditches are in isolated surge plains. Longview, Washington, in Reach D has an extensive network of ditches and is somewhat unusual in that the largest ditch area is also a feature (artificial channel) within the developed ecosystem complex. Reach E is also somewhat unusual in that most ditches are part of the volcanogenic delta complex, where they are associated with agricultural land on the Lewis River volcanogenic delta. In Reach F, most ditches are in protected floodplain backswamp areas, commonly in lake beds. Ditches are also in backswamp lake beds in the lower part of Reach G, but most are in the heavily altered floodplain between Portland International Airport and the Sandy River delta.

Railroad is present in all reaches. The largest areas of railroad are in Reaches D, $\mathrm{G}$, and $\mathrm{H}\left(1.3,0.9\right.$, and $0.8 \mathrm{~km}^{2}$ respectively). The reaches with the largest areal proportion that is railroad are Reaches $\mathrm{D}, \mathrm{H}$, and $\mathrm{G}$, all of which are $1 \%$ railroad $(126$, $78,86 \mathrm{~km}^{2}$ respectively). Railroad is generally along the edge of the floodplain and commonly above it where there are gentle slopes. In Reach H, railroad commonly crosses landslide toes and tributary fans

Undifferentiated excavations (excavation/cut) are present in all reaches, and are generally less than one-half $\%$ of the reach area. The largest area of mapped excavation/cut is in Reach $\mathrm{H}$, where excavations are one $\%\left(0.06 \mathrm{~km}^{2}\right)$ of the reach area. Most of the excavation/cut area in Reach $\mathrm{H}$ is the excavated channels at Bonneville Dam for navigation lock approaches and for the powerhouse built in 1974. Excavations 
elsewhere are commonly small cuts for roads or railroads, but also include quarries, such as the site of Mount Coffin near Longview. 


\section{Chapter 4: Assessments of widespread anthropogenic influence}

I used several geographic information system based analyses of the Classification datasets, topography, water levels, and historical data to assess changes that may owe to human influences.

\section{Effects of changed hydrograph and isolation on hydroperiod}

Floodplain and surge plain landforms in the study area consist of material deposited by flowing water. Their growth is therefore influenced by the frequency and duration of inundation. Factors influencing inundation patterns along the Columbia River include streamflow, tides, and isolation by flood-control levee systems.

Inventory of Floodplain Isolation

Flood-control levee construction along the lower Columbia River began in the late 1800s (Christy and Putera, 1993; Bischoff and others, 2000), and by 1948 more than one-half of the floodplain along the lower Columbia River had been isolated from flooding. Most floodplain isolation owes to levees and flood control measures, but locally is a result of infrastructure or other fill. Polygons from the Ecosystem Complex level of the Classification were used to create an inventory of isolated areas within the floodplain. Polygons were classified based on their connection to streamflow and tides. Initial classifications included: connected, isolated, impaired, high feature, or unprotected high feature (Figure 19). Impaired areas were differentiated from isolated areas based on lack of subsidence, known culvert connection, or appearance in lidar or aerial photographs. Only the areas classified as isolated will be further discussed in this analysis. 
As of $2010,462 \mathrm{~km}^{2}$ of the study area is isolated from inundation, not including developed floodplain areas built up above the limit of flooding. Most floodplain isolation owes to levees and flood control measures, but locally is a result of infrastructure or other fill. Most ecosystem complexes have some area that is isolated, but most is in isolated surge plain (35\%), floodplain backswamp (13\%), undifferentiated floodplain (11\%), volcanogenic delta $(11 \%)$, or floodplain ridge and swale $(10 \%)$ complexes. Aside from isolated surge plains, which are the only ecosystem complex specifically associated with isolation, volcanogenic deltas have the highest proportion of total area that is isolated (86 \%). Floodplain backswamp, undifferentiated floodplain, and floodplain ridge and swale all have about one-half of their total area isolated by flood-control levee systems and nearly $65 \%$ of crevasse splays are within areas protected by levees.

Table 6. Area of ecosystem complexes with more than $1 \mathrm{~km}^{2}$ of isolated area, sorted by area of isolation.

\begin{tabular}{lccc}
\hline \multicolumn{1}{c}{ Ecosystem Complex } & $\begin{array}{c}\text { Total Complex } \\
\text { Area }(\mathbf{k m 2})\end{array}$ & $\begin{array}{c}\text { Isolated Area } \\
\mathbf{( k m 2 )}\end{array}$ & $\begin{array}{c}\text { Isolated } \\
\text { Fraction }\end{array}$ \\
\hline Isolated surge plain & 164 & 161 & 0.98 \\
Floodplain backswamp & 122 & 61.6 & 0.50 \\
Floodplain & 98.1 & 51.3 & 0.52 \\
Volcanogenic delta & 58.9 & 50.5 & 0.86 \\
Floodplain ridge and swale & 85.7 & 46.2 & 0.54 \\
Developed & 82.0 & 34.3 & 0.42 \\
Crevasse splay & 29.8 & 19.2 & 0.65 \\
Dune & 48.5 & 11.0 & 0.23 \\
Terrace & 20.5 & 10.9 & 0.53 \\
Tributary floodplain & 42.7 & 5.63 & 0.13 \\
Tributary fan & 20.0 & 5.50 & 0.27 \\
Dredge disposal area & 30.9 & 2.39 & 0.08 \\
\hline
\end{tabular}


Reach $\mathrm{H}$ is the only reach that does not have an extensive area of isolated floodplain, though much of it is partly isolated by highway fill and could be considered "impaired" (partially isolated). The reaches with the most isolated area are Reaches F and C. Some of the largest contiguous isolated areas are Sauvie Island, Portland from Interstate 5 to the Sandy River, Longview, Woodland, Vancouver, Clatskanie, Scappoose, Deer Island, and Westport.

\section{Assessment of Changed Streamflow}

The streamflow regime has been affected by flow-regulation, climate change, and water withdrawals (Naik and Jay, 2005, Naik and Jay, 2011). U.S. Geological Survey stream gage (USGS 14105700) has measured streamflow at or near The Dalles, Oregon since 1878 and is used to assess changes in Columbia River streamflow. The period 1890 to 1944 predates most storage dams in the Columbia River Basin and includes both warm and cool phases of the Pacific decadal oscillation (Naik and Jay, 2011, Figure 4). The period 1970 to 2013 post-dates construction of most storage dams in the basin and is used to represent post-regulation flow conditions. Spring freshets are typically highest in late May or June (Figures 4 and 18) and median peak daily flows at The Dalles for the preand post-regulation periods are $16,300 \mathrm{~m}^{3} \mathrm{~s}^{-1}$ and $10,900 \mathrm{~m}^{3} \mathrm{~s}^{-1}$ respectively. Median of daily streamflow for June at The Dalles for the pre- and post-regulation periods is 12,800 $\mathrm{m}^{3} \mathrm{~s}^{-1}$ and $7,900 \mathrm{~m}^{3} \mathrm{~s}^{-1}$ respectively. 


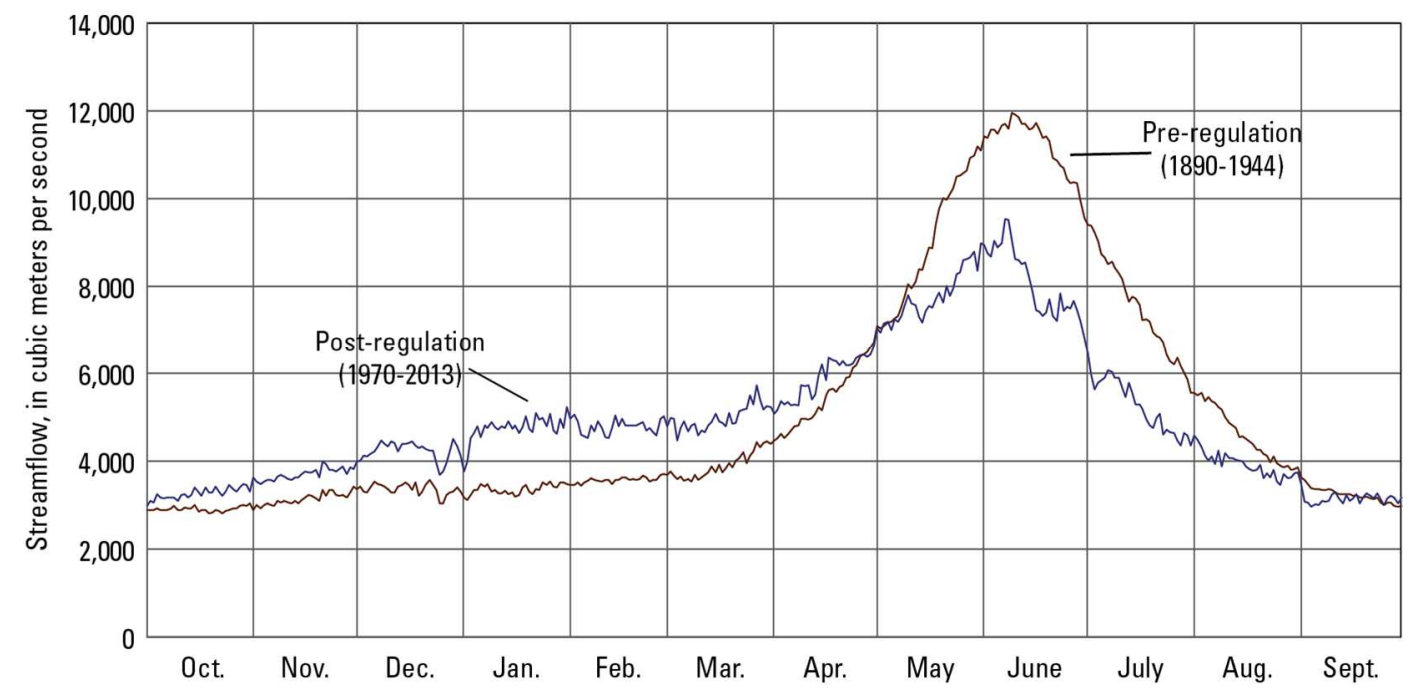

Figure 18. Median daily streamflow at The Dalles, Oregon for pre- and post-regulation periods.

Hourly water levels are available for water years 2008 to 2013 at Astoria,

Skamokawa, Wauna, Beaver (Port Westward), Longview, St. Helens, Vancouver, and below Bonneville Dam (Figure 19). Interpolation between these stations is used to generate statistical water surfaces that are used to estimate potential inundation for landforms along the estuary. Median and maximum water levels were calculated at each gaging station over calendar month periods representing post-regulation conditions. The values at gaging stations were used to create a water surface profile as a function of Columbia River mile. Linear interpolation was used to fill gaps between the gaging stations. The interpolated water levels were assigned to polygons representing Columbia River miles and used to classify each cell in the digital terrain model as to whether it was above or below the river stage. The classified cells were converted to smoothed polygons. Data gaps in terrain model and polygons smaller than $100 \mathrm{~m}^{2}$ were dissolved into the adjacent polygon with the longest shared border. For historical floods, USACE (1968, 
Figure 5) flood profiles showing water levels by Columbia River mile were converted to NAVD 88 and used to construct polygons representing potential inundation.

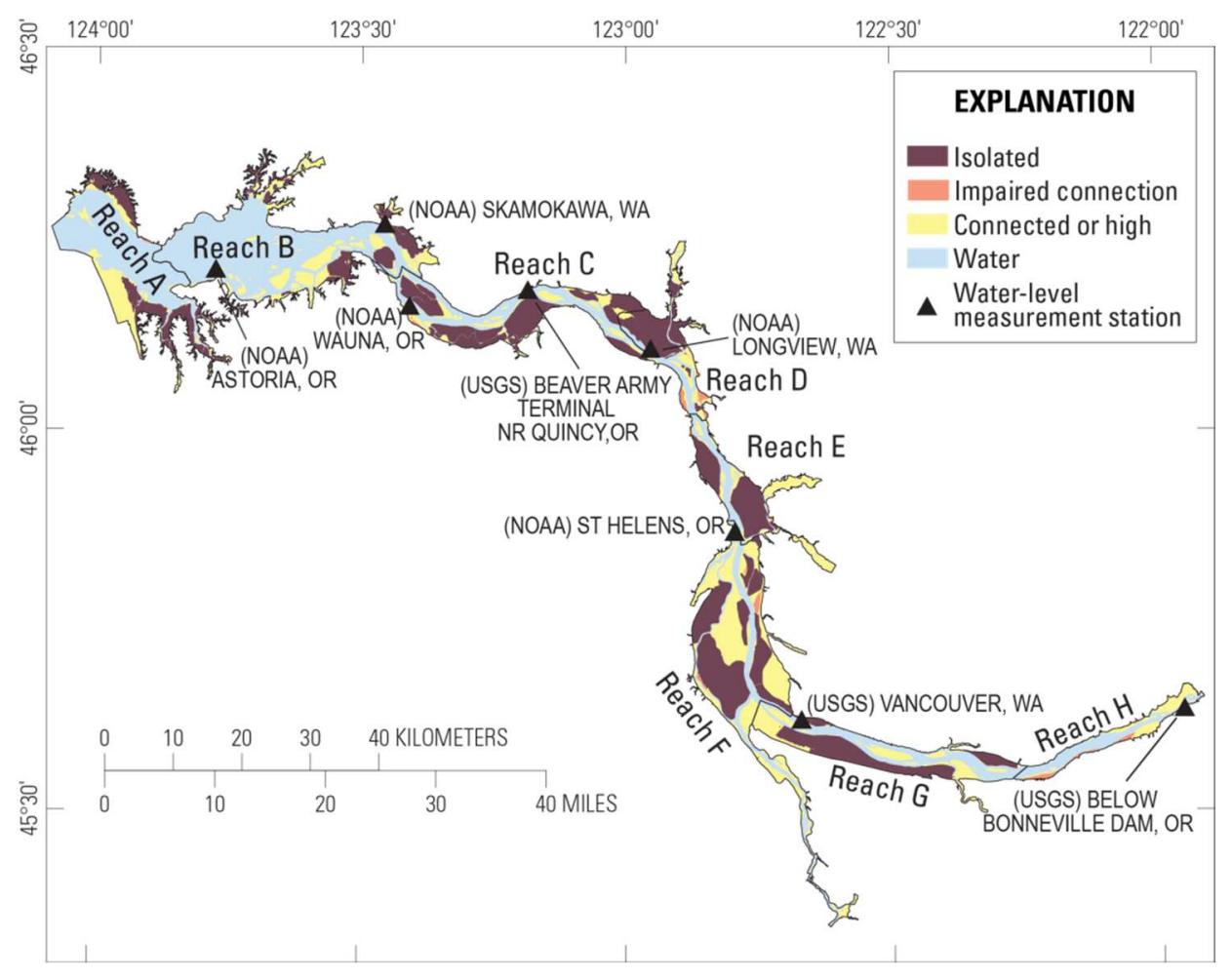

Figure 19. Map showing classification of isolated areas and locations of water-level measurement stations used to create statistical water surfaces; NOAA, National Oceanic and Atmospheric Administration; USGS, U.S. Geological Survey.

To assess changes in inundation patterns, I overlaid the Classification, the inventory of isolated areas, on polygons of potential inundation. The flood of June, 1894 is the flood of record and considered the maximum possible inundated area. June, 1946 was used to represent typical pre-regulation peak flows. Median post-regulation peak streamflow is most closely represented by April, 2011 (Table 7). However, since April is before typical freshets and likely more influenced by lower-basin tributaries, June of 2009 and 2010 are used to bracket the median post-regulation flow scenario. The 
calendar month of September, 2009 has the lowest maximum streamflow at The Dalles for the 2008 to 2013 water years and is used to assess the contribution of tides to inundation.

This assessment of potential inundation assumes that 1) levees are completely effective 2) water surface profiles are linear between gages, 3) flow contributions to spring freshets from below The Dalles are equally proportional to flow measured at The Dalles, and 4) the water levels would be the same with and without flood-control levees. One notable uncertainty is that most floodplain water bodies are represented in the terrain model by the water surface at time of lidar collection (Winter 2009-2010). Therefore, the area of these landforms lower than the water surface is potentially underestimated in this analysis. Backswamp lakes are the largest floodplain waterbodies and therefore most likely to be misrepresented.

Table 7. Streamflow scenarios used to assess changes in potential inundation. Median and maximum streamflow were calculated from daily mean streamflow at The Dalles gage (USGS 14105700). Median annual maximum streamflow for the period $1890-1944$ is $16,300 \mathrm{~m}^{3} \mathrm{~s}^{-1}$ and for $1970-2013$ is $10,900 \mathrm{~m}^{3} \mathrm{~s}^{-1}$.

\begin{tabular}{lrll}
\hline \multicolumn{1}{c}{ Month } & $\begin{array}{c}\text { Maximum } \\
\left(\mathbf{m}^{3} \mathbf{s}^{-1}\right)\end{array}$ & \multicolumn{1}{c}{ Purpose } & \multicolumn{1}{c}{ Source of water surface } \\
\hline June, 1894 & 34,800 & maximum historical freshet & USACE (1968) flood profiles \\
June, 1946 & 16,300 & median pre-regulation freshet & USACE (1968) flood profiles \\
June, 2009 & 10,400 & median post-regulation freshet & interpolation from gages \\
June, 2010 & 11,900 & median post-regulation freshet & interpolation from gages \\
September, 2009 & 3,100 & minimal fluvial influence & interpolation from gages \\
\hline
\end{tabular}


Effects of changed hydrograph and isolation on hydroperiod

Without flood-control levees, $96 \%$ of floodplain and surge plain landforms would be inundated by a flood similar to the 1894 freshet. This includes $100 \%$ of crevasse splay, $85 \%$ of generic floodplain, $99 \%$ of floodplain backswamp, $98 \%$ of floodplain ridge and swale, and 99 percent of surge plain ecosystem complexes. Locally, anthropogenic fill has reduced the area of inundation, particularly for the generic floodplain ecosystem complex, where extensive direct landscape modification has occurred. With flood-control levees, $35 \%$ of crevasse splay, $37 \%$ of generic floodplain, $49 \%$ of floodplain backswamp, $44 \%$ of floodplain ridge and swale, and $34 \%$ of surge plain ecosystem complexes. I consider the 1894 freshet as representative of maximum water levels that could be expected for the Classification study area. Without isolation, $764 \mathrm{~km}^{2}$ (49 \%) of the Classification area would be land available for inundation. With isolation, only $326 \mathrm{~km}^{2}(21 \%)$ of the Classification area consists of land that is available for inundation.

For the median pre-regulation freshet (June, 1946) without flood-control levees, $98 \%$ of crevasse splay, $66 \%$ of generic floodplain, $98 \%$ of floodplain backswamp, $85 \%$ of floodplain ridge and swale, and $94 \%$ of surge plain ecosystem complexes would be inundated. With flood-control levees, $35 \%$ of crevasse splays, $26 \%$ of generic floodplain, $49 \%$ of floodplain backswamp, $39 \%$ of floodplain ridge and swale, and $32 \%$ of surge plain complexes would be inundated.

To approximate the theoretical median post-regulation freshet of $10,900 \mathrm{~m}^{3} \mathrm{~s}^{-1}, \mathrm{I}$ use June, 2009 and June, 2010 to provide a range of potential inundation. Without floodcontrol levees, 53 to $80 \%$ of crevasse splays, 21 to $38 \%$ of generic floodplain, 89 to 95 
$\%$ of floodplain backswamp, 31 to $52 \%$ of floodplain ridge and swale, and $93 \%$ of surge plain complexes would be inundated. With flood control-levees, 23 to $32 \%$ of crevasse splays, 9 to $16 \%$ of generic floodplain, 46 to $48 \%$ of floodplain backswamp, 12 to $23 \%$ of floodplain ridge and swale, and 32 to $31 \%$ of surge plain complexes would be inundated.

For the low streamflow scenario of September, 2009, maximum stage would inundate $12 \%$ of crevasse splay, $3 \%$ of generic floodplain, $44 \%$ of floodplain backswamp, $9 \%$ of floodplain ridge and swale, and $81 \%$ of surge plain complexes. With flood-control levees, $22 \%$ of floodplain backswamp and $23 \%$ of surge plains would be inundated. It should be noted however, that the area of floodplain backswamp inundated is an underestimate, because lake elevations in the terrain model are largely based on water surface elevations instead of bathymetry.

Table 8. Potential and actual inundation of ecosystem complexes below maximum water surface elevation.[P.I., potential inundation; A.I., actual inundation]

\begin{tabular}{|c|c|c|c|c|c|c|c|c|c|c|c|}
\hline \multirow{2}{*}{ Ecosystem Complex } & \multirow{2}{*}{$\begin{array}{l}\text { Total } \\
\text { area } \\
\left(\mathrm{km}^{2}\right)\end{array}$} & \multicolumn{2}{|c|}{$\begin{array}{c}\text { June, } 1894 \\
\left(\mathrm{~km}^{2}\right)\end{array}$} & \multicolumn{2}{|c|}{$\begin{array}{c}\text { June, } 1946 \\
\left(\mathrm{~km}^{2}\right)\end{array}$} & \multicolumn{2}{|c|}{$\begin{array}{c}\text { June, } 2010 \\
\left(\mathrm{~km}^{2}\right)\end{array}$} & \multicolumn{2}{|c|}{$\begin{array}{c}\text { June, } 2009 \\
\left(\mathrm{~km}^{2}\right)\end{array}$} & \multicolumn{2}{|c|}{$\begin{array}{c}\text { Sept., } 2009 \\
\left(\mathrm{~km}^{2}\right)\end{array}$} \\
\hline & & P.I. & A.I. & P.I. & A.I. & P.I. & A.I. & P.I. & A.I. & P.I. & A.I. \\
\hline Crevasse splay & 30 & 30 & 11 & 29 & 10 & 24 & 9 & 16 & 7 & 3 & 1 \\
\hline Floodplain & 98 & 83 & 36 & 65 & 26 & 37 & 15 & 21 & 9 & 3 & 1 \\
\hline Floodplain backswamp & 122 & 122 & 60 & 120 & 60 & 117 & 59 & 109 & 56 & 54 & 26 \\
\hline Floodplain ridge and swale & 86 & 84 & 38 & 73 & 33 & 45 & 19 & 27 & 10 & 7 & 2 \\
\hline Surge plain & 246 & 242 & 83 & 232 & 80 & 228 & 77 & 230 & 78 & 200 & 55 \\
\hline $\begin{array}{l}\text { Total floodplain and surge } \\
\text { plain }\end{array}$ & 582 & 561 & 228 & 520 & 209 & 450 & 180 & 401 & 160 & 268 & 86 \\
\hline
\end{tabular}




\section{Subsidence of Surge Plains}

Elevations of wetlands, such as surge plains are largely a balance between accumulation of organic and mineral materials, decomposition and oxidation of organic materials, sediment compaction, erosion by wind and water, and tectonic influences. Organic material can be detritus transported from elsewhere or from vegetative growth. Wetland hydrology influences elevation through delivery of materials entrained in surface water, and through regulation of plant growth, microbial decomposition, and oxidation state by ground water (Cahoon and others, 2006).

Draining wetlands, such as surge plains lowers the ground water surface, which improves soil aeration and decreases buoyancy. Initial subsidence of drained organic-rich soils, such as histosols, is likely a result of soil consolidation and loss of buoyancy (Stephens and others, 1984). It is accompanied and followed by subsidence owing to decomposition and autocompaction (Kaye and Barghoorn, 1964; Tornqvist and others, 2008) of organic material, which varies according to concentration of organic matter (Rojstaczer and Deverel, 1993). Livestock grazing or mechanized agriculture can further contribute to soil compaction (Mitchell, 1981). Isolation of wetlands from inundation prevents accumulation of new water-transported material.

Surge plains along the Columbia River estuary that are enclosed by flood control levee systems commonly have lower apparent elevations than surge plains that are open to the influence of tides. During the course of mapping the Classification, I attributed surge plains as subsided, not subsided, or unknown subsidence. Of all mapped surge plains and isolated surge plains, $62 \%\left(150 \mathrm{~km}^{2}\right)$ have apparently subsided and for $7 \%$ $\left(17 \mathrm{~km}^{2}\right)$, I am uncertain whether or not they have subsided. 
Assessment of relative subsidence

To quantify the amount of subsidence, I compare averaged elevations of surge plain sites with similar landcover classification, but different isolation status. Average lidar elevation was calculated using zonal statistics with zones made by intersecting landcover segment polygons with the Classification polygons. Cultural features were omitted and where possible small unmapped tidal channels were avoided. The areas analyzed at each site averaged about $50,000 \mathrm{~m}^{2}$, but ranged from $14,900 \mathrm{~m}^{2}$ to $119,000 \mathrm{~m}^{2}$.

With the exclusion of one outlier, lidar ground surface measurements at eight isolated surge plain sites average $0.9 \mathrm{~m}$ lower than nearby non-isolated surge plains with differences ranging from 0.4 to $1.4 \mathrm{~m}$ (Table 9). These subsidence values are consistent with subsidence measured for other Oregon tidal wetlands (Frenkel and Morlan, 1991; Cornu and Sadro, 2002). The outlier site is northeast of Clatskanie, Oregon along Beaver Dredge Cut, where the isolated surge plain is $2.9 \mathrm{~m}$ lower than the lower flooded surge plain along Beaver Dredge Cut. An example of an isolated surge plain that has apparently subsided is near Brownsmead, Oregon, where an area shown as having uniform land cover in 1870 (Figure 20) is now nearly one meter lower than the adjacent non-isolated surge plain (Figure 21). 
Table 9. Sites used to assess subsidence of isolated surge plains. "Connected" refers to locations that are not isolated by flood-control levees. "Isolated" refers to areas that are isolated by flood-control levees. [NAVD 88, North American Vertical Datum of 1988]

\begin{tabular}{|c|c|c|c|c|c|c|}
\hline Site & Land cover & $\begin{array}{l}\text { Location, } \\
\text { connected }\end{array}$ & $\begin{array}{l}\text { Meters NAVD } \\
88, \text { connected }\end{array}$ & $\begin{array}{l}\text { Location, } \\
\text { isolated }\end{array}$ & $\begin{array}{l}\text { Meters NAVD } \\
88, \text { isolated }\end{array}$ & $\begin{array}{l}\text { Meters of } \\
\text { apparent } \\
\text { subsidence }\end{array}$ \\
\hline $\begin{array}{l}\text { Chadwell, upper Lewis } \\
\text { and Clark River }\end{array}$ & coniferous wetland forest & $\begin{array}{l}123^{\circ} 50^{\prime} 39^{\prime \prime} \\
46^{\circ} 05^{\prime} 24^{\prime \prime}\end{array}$ & 2.8 & $\begin{array}{l}123^{\circ} 50^{\prime} 40^{\prime \prime} \\
46^{\circ} 05^{\prime} 33^{\prime \prime}\end{array}$ & 2.4 & 0.4 \\
\hline Wallooskee River & wetland herbaceous & $\begin{array}{l}123^{\circ} 47^{\prime} 22^{\prime \prime} \\
46^{\circ} 08^{\prime} 35^{\prime \prime}\end{array}$ & 2.6 & $\begin{array}{l}123^{\circ} 47^{\prime} 1 " \\
46^{\circ} 08^{\prime} 24^{\prime \prime}\end{array}$ & 1.9 & 0.8 \\
\hline $\begin{array}{l}\text { Klaskanine/Youngs } \\
\text { River confluence, } \\
\text { herbaceous }\end{array}$ & $\begin{array}{l}\text { wetland } \\
\text { herbaceous/agriculture }\end{array}$ & $\begin{array}{l}123^{\circ} 46^{\prime} 58^{\prime \prime} \\
46^{\circ} 05^{\prime} 58^{\prime \prime}\end{array}$ & 2.7 & $\begin{array}{l}123^{\circ} 46^{\prime} 32^{\prime \prime} \\
46^{\circ} 05^{\prime} 44^{\prime \prime}\end{array}$ & 1.4 & 1.3 \\
\hline $\begin{array}{l}\text { Klaskanine/Youngs } \\
\text { River confluence, } \\
\text { forested }\end{array}$ & coniferous wetland forest & $\begin{array}{l}123^{\circ} 45^{\prime} 24^{\prime \prime} \\
46^{\circ} 05^{\prime} 48^{\prime \prime}\end{array}$ & 3.1 & $\begin{array}{l}123^{\circ} 45^{\prime} 48^{\prime \prime} \\
46^{\circ} 05^{\prime} 43^{\prime \prime}\end{array}$ & 2.1 & 1.0 \\
\hline Grays River mouth & coniferous wetland forest & $\begin{array}{l}123^{\circ} 41^{\prime} 21^{\prime \prime} \\
46^{\circ} 18^{\prime} 41^{\prime \prime}\end{array}$ & 2.8 & $\begin{array}{l}123^{\circ} 40^{\prime} 24^{\prime \prime} \\
46^{\circ} 18^{\prime} 07^{\prime \prime}\end{array}$ & 2.3 & 0.6 \\
\hline Brownsmead & coniferous wetland forest & $\begin{array}{l}123^{\circ} 33^{\prime} 50^{\prime \prime} \\
46^{\circ} 12^{\prime} 40^{\prime \prime}\end{array}$ & 2.9 & $\begin{array}{l}123^{\circ} 33^{\prime} 39^{\prime \prime} \\
46^{\circ} 12^{\prime} 45^{\prime \prime}\end{array}$ & 2.2 & 0.8 \\
\hline Skamokawa & deciduous wetland forest & $\begin{array}{l}123^{\circ} 27^{\prime} 8^{\prime \prime} \\
46^{\circ} 16^{\prime \prime} 3^{\prime \prime}\end{array}$ & 3.0 & $\begin{array}{l}123^{\circ} 26^{\prime} 47^{\prime \prime} \\
46^{\circ} 15^{\prime} 59^{\prime \prime}\end{array}$ & 2.2 & 0.8 \\
\hline Willow Grove & wetland herbaceous & $\begin{array}{l}123^{\circ} 02^{\prime} 4^{\prime \prime} \\
46^{\circ} 10^{\prime} 19^{\prime \prime}\end{array}$ & 3.0 & $\begin{array}{l}123^{\circ} 01^{\prime} 33^{\prime \prime} \\
46^{\circ} 10^{\prime} 10^{\prime \prime}\end{array}$ & 1.6 & 1.4 \\
\hline Beaver Dredge Cut & $\begin{array}{l}\text { wetland } \\
\text { herbaceous/agriculture }\end{array}$ & $\begin{array}{l}123^{\circ} 11^{\prime} 14^{\prime \prime} \\
46^{\circ} 07^{\prime} 29^{\prime \prime}\end{array}$ & 2.6 & $\begin{array}{l}123^{\circ} 11^{\prime} 21^{\prime \prime} \\
46^{\circ} 07^{\prime} 41^{\prime \prime}\end{array}$ & -0.3 & 2.9 \\
\hline
\end{tabular}




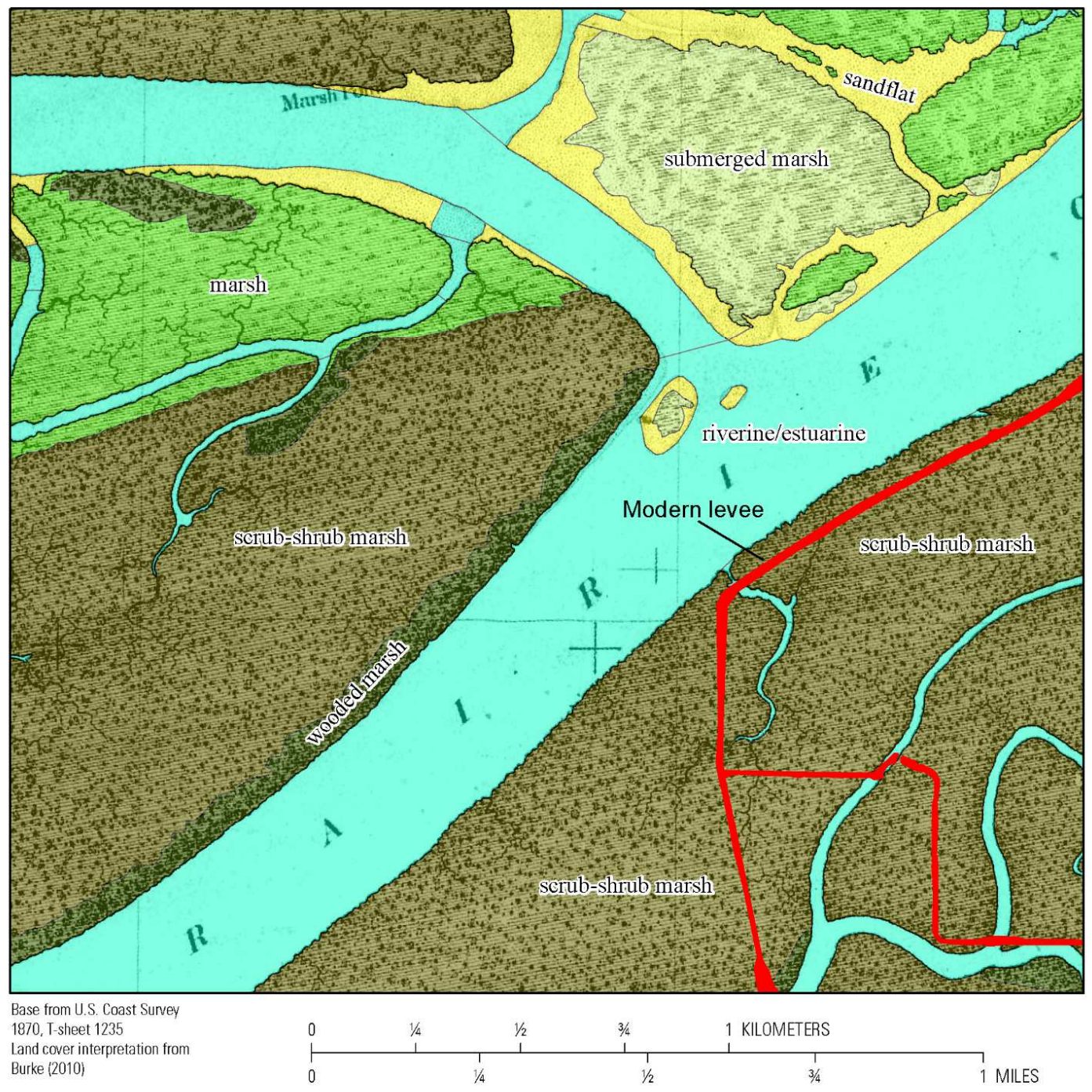

Figure 20. Part of U.S. Coast and Geodetic Survey T-sheet 1235 showing historical land cover along Prairie Channel near Brownsmead, Oregon as mapped in 1870. Red linear polygon shows location of modern flood-control levees. Shading and land cover units are from Burke (2010). 


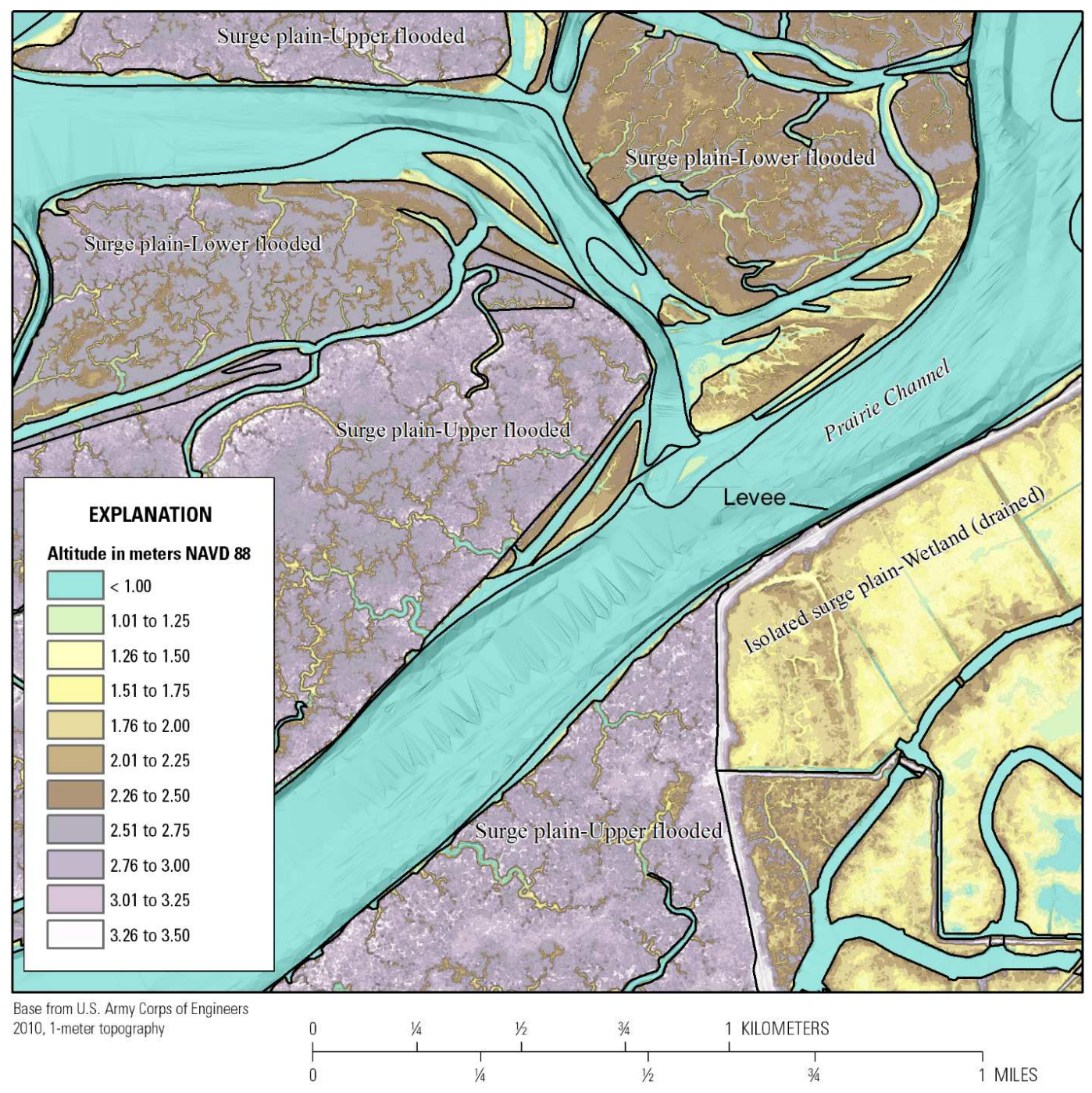

Figure 21. Surge plains and isolated surge plains along Prairie Channel near Brownsmead, Oregon symbolized by classified elevation. Note the lower altitude of the isolated surge plain complex.

\section{Suitability of Lidar for Subsidence Assessment}

One uncertainty with subsidence assessments from lidar terrain models is the influence of vegetation. Since most areas of apparent subsidence are used for agricultural 
purposes, land cover is generally short herbaceous vegetation, presumably with minimal terrain model error. Areas not protected from flooding are commonly scrub-shrub or forested wetlands, leading to the possibility of apparent greater differences in elevation than are actually present. Hood (2007) found that ground elevations obtained from lidar with $3-\mathrm{m}$ average point spacing and $15 \mathrm{~cm}$ vertical accuracy averaged $0.7 \mathrm{~m}$ higher than surveyed elevations in dense scrub-shrub vegetation.

Two upper flooded surge plain sites at Blind Slough swamp near Brownsmead, Oregon were used by Brophy and others (2011) to develop a reference conditions database for tidal wetland restoration, a forested (Sitka spruce) swamp, and a scrub-shrub (willow) swamp. Comparison of lidar elevations with survey points from Brophy and others (2011) indicates that lidar over-predicts elevation of both forest and scrub-shrub wetlands by as much as 0.3 meters.

\section{Clatskanie Anomalous Subsidence}

The floodplain between Port Westward and the Clatskanie River is the lowest floodplain along the estuary and the only place where an extensive land area is lower than low water datum. Aside from subtle natural levees along remnant tidal channels, all of the interior Clatskanie floodplain is shown as "marsh" on Coast and Geodetic Survey maps from 1874 and 1876 and is the largest contiguous expanse of non-wooded 'marsh' shown on the earliest Coast and Geodetic Survey maps of the Columbia River. A General Land Office Map from 1856 describes the area as "Low swampy prairie with willow brush in patches and intersected by many tidal sloughs. The whole bottom is subject to overflow." 
The lower parts of the Clatskanie floodplain are mapped as Crims Series soils (Terric Medihemists), which are described by Smythe (1986) as forming in concave floodplain areas from partially decomposed herbaceous plant material underlain by silty alluvium. The type location of the Crims series is in the Clatskanie floodplain near where Beaver Creek enters the Columbia River valley (Smythe, 1986) and is below 0 m NAVD 88. The Clatskanie floodplain is mostly enclosed by flood control levees and is drained by an extensive network of ditches. The Clatskanie floodplain was mostly cultivated fields or pasture by 1951 and much of the area is now used for tree farming. Peterson and others (2012) document tephra from eruptions 4, 3, and 1.3 thousand years ago within 5 $\mathrm{m}$ of "sea level" in the subsurface at the upstream end of the isolated surge plain containing the low areas, indicating the channel has not occupied the south side of the valley for at least 4,000 years.

The low floodplains at Clatskanie have apparently subsided more than elsewhere along the Columbia River estuary. One possible explanation for the unusually low ground surface is that it was more enriched in organic matter than floodplains elsewhere along the Columbia River estuary and that oxidation of this organic matter has resulted in more subsidence than elsewhere. The low area is the largest expanse of floodplain histosols mapped by NRCS along the Columbia River estuary. A relatively low energy marsh environment persisting for thousands of years in a slowly aggrading setting may have enabled accumulation of more organic matter than on floodplains that are more frequently reset by channel migration or are more frequently affected by fluvial flooding (vs. tidal inundation). Its position near the limit of coseismic subsidence may also contribute to a higher proportion of organic material. Sudden coseismic subsidence 
creates accommodation space and increases the duration of tidal inundation, which favors accumulation of detrital material. Aggradation that is mostly a function of steady (eustatic) sea-level rise would lack these pulses of clastic material and would favor continued vegetative growth, and thus accumulation of organic matter.

\section{Lateral Erosion and Deposition}

I overlaid the Columbia River primary channel and historical landcover from Tsheets (Burke, 2010) to assess areas of lateral erosion and deposition. This analysis only covers the areas along the primary channel from near Ilwaco, Washginton to near Washougal, Washington. Changes were classified as erosion, deposition, or no change, and discarded the no-change polygons. These erosion and deposition polygons were superimposed (intersected) with the Classification map to assess what landforms had accreted and eroded. Distances to dredge disposal areas were used to infer if there is a relationship between accreted land and dredge material deposition other than the dredge material deposits themselves.

Results indicate that $48.7 \mathrm{~km}^{2}$ of land has accreted, and $26.9 \mathrm{~km}^{2}$ has eroded (Appendix B). Reach B is the only reach where there has been a greater area of erosion than deposition along the primary channel. About one-third of the deposition area is dredge disposal and some is fill for infrastructure. Some notable areas of deposition that are not directly anthropogenic include the downstream ends of islands, such as Reed Island, and downstream of bends in the channel, such as Cottonwood Point near Washougal, Washington and an unnamed point at Goble, Oregon. Some of the largest contiguous areas of deposition adjacent to the Columbia River primary channel are at the 
upstream end of Puget Island, Cottonwood Island near the Cowlitz River confluence, and west Sand Island near the entrance.

The second most extensive geomorphic catena (14\%) that has accreted is lower flooded surge plain. These are generally emergent surge plain islands in Reach B, but are also areas downstream of dredge material disposal areas (such as at Puget Island), and accreted shoreline, such as around Baker Bay and near Aldrich Point. More than one-half (59\%) of the accreted lower flooded surge plains are in Reach B. on the T-sheets, these areas were either 'riverine/estuarine' $(60 \%)$ or sand flat ( $40 \%)$. percentages of lower flooded surge plain in reaches A and C that were historically 'riverine/estuarine' were 84 and $96 \%$ respectively. About $58 \%$ of the accreted lower flooded surge plains in Reach C are within $500 \mathrm{~m}$ of dredge material areas. Examples are near the upstream end of Puget Island, Lord Island, and along Fisher and Crims Islands. Most of these examples are on the side of the dredge disposal area that faces away from the maintained navigation channel.

Wetlands are the third most extensive (9\%) catena that has accreted/deposited. Most of the accreted wetlands are in reaches $\mathrm{C}, \mathrm{E}$, and $\mathrm{D}(40,21$, and $18 \%$ respectively). About $90 \%$ of accreted wetlands in reaches C-F are within $1 \mathrm{~km}$ of dredge material disposal areas and $80 \%$ are within $500 \mathrm{~m}$. Most of the wetlands accreted in Reach C are on islands downstream of dredge material disposal areas, such as Lord, Crims, and Fisher Islands. Similarly, most accreted wetlands in Reach $\mathrm{E}$ are downstream of dredge material disposal areas such as Goat and Sandy Islands, the downstream end of Deer Island, and along the Lewis River volcanogenic delta. Some wetland accretion has also occurred along Martin Slough. Most (86 \%) accreted wetlands in Reach D are along Carrolls 
Channel near Dredge disposal sites on Cottonwood Island. An accreted wetland downstream from the Goble Creek confluence is a notable exception that is probably not associated with dredge material disposal.

Natural levee is the fourth most extensive catena that has accreted/deposited. Most accreted natural levees are in reaches $\mathrm{G}, \mathrm{C}$, and E (44, 20, and $23 \%$ respectively). Most of the natural levee area that has accreted in Reach $\mathrm{G}$ is on islands, most notably the downstream end of Reed Island. The accreted natural levees in Reach G are somewhat different in that they are mostly more than one kilometer from known (mapped) dredge material disposal areas. Most accreted/deposited natural levees in Reach $\mathrm{C}$ are in floodplain ridge and swale complexes, and are mostly on islands between Port Westward and Longview. About half of the accreted Reach $\mathrm{C}$ natural levees are within 500 meters of known (mapped) dredge material disposal areas. Accreted natural levees in Reach $\mathrm{E}$ are mostly on Sandy, Deer, Martin, and Burke Islands. Those on Sandy and Deer Island are near dredge material disposal areas, but on Martin and Burke Islands have accreted along secondary channels (Martin and Burke Sloughs). It is likely that at least some of the accreted natural levees are older dredge material disposal areas, particularly in Reaches C, D, and E.

Most of the eroded floodplain areas were historically submerged marsh, woodland, wooded marsh, or marsh. Submerged Marsh would likely be part of the lower flooded surge plain complex. Nearly all of the eroded submerged marsh (99\%) area was historically in Reach B among the bay-head delta islands and in Gray's Bay. The eroded marshes in Reach B are now intermittently exposed (51\%), Permanently flooded (43\%), or Deep channel (6\%) geomorphic catenae. 
Wooded (non-marsh) floodplain has eroded in all reaches assessed, but mostly in Reaches G, F, E, and D $(45,21,12$, and $11 \%$ respectively). Nearly half of the wooded floodplain erosion has been in Reach G, where it is mostly along edges of islands. In Reach F, wooded floodplain erosion is along channel margins and likely corresponds to erosion of ridge and swale or floodplain natural levees. Wooded floodplain erosion in Reach E represents erosion of the Lewis River volcanogenic delta and natural levees in floodplain ridge and swale areas. Wooded floodplain erosion in Reach D mostly corresponds to loss of floodplain ridge and swale or generic floodplain natural levees.

About $20 \%$ of the eroded floodplain area was historically wooded marsh, mostly in Reaches B and C. Wooded Marsh is likely equivalent to the upper flooded surge plain geomorphic catena of the Classification. One notably large area of wooded marsh erosion is along the primary channel extending from near Cathlamet, Washington, to about 1.5 km downstream of Skamokawa, Washington including Hunting and Price Islands. In 1871, Price Island covered an area of about $1 \mathrm{~km}^{2}$ but by 2010 it was $0.4 \mathrm{~km}^{2}$. Price Island and the nearby surge plains are apparently still eroding, and in 2012, part of a flood control levee began falling into the river threatening a road and wildlife refuge protected by the dike (Columbia River Estuary Task Force, 2013)

About $15 \%$ of the eroded floodplain area was historically "marsh", mostly in Reach B, and is likely equivalent to the lower flooded surge plain geomorphic catena of the Classification.

Although upstream from the area of this overlay analysis, comparison of aerial photographs shows that the wooded area of Skamania Island in Reach G decreased from $0.7 \mathrm{~km}^{2}$ in 1953 to less than $0.01 \mathrm{~km}^{2}$ in 2009 . 


\section{Changes in distribution of deep channel and/or thalweg}

Since the late 1800s, the Columbia River channel has been used as a navigation channel to Portland. Navigation channel maintenance operations include dredging and a system of pile dikes. The pile dikes are commonly associated with dredge material disposal areas and function to concentrate flow to the main (navigation) channel, enhancing scour and reducing the need for maintenance dredging (Willingham, 1983). I assessed changes in bathymetry of primary and some secondary channels by assigning terrain model elevations to U.S. Coast and Geodetic Survey points digitized and converted to NAVD 88 by Burke (2009). Comparison of historical bathymetry point data from Burke (2009) with modern topography shows that 1) the primary channel is narrower, and generally has shallower margins, 2) deep channel areas are more continuous than they were historically 3 ) most secondary channels have aggraded. 


\section{Chapter 5: Summary and Conclusion}

The Columbia River estuary was historically a complex system of channels with a floodplain dominated by extensive tidal wetlands below Longview and backswamp lakes and wetlands in the Portland Basin. Natural levees flank most channels upstream of Longview, locally including areas of ridge and swale topography and crevasse splays intruding into backswamps. Localized non-fluvial and external process domains affecting floodplain morphology have included volcanogenic deltas, tributary fans, dunes, and landslides. Pre-Holocene landforms are locally prominent and include ancient fluvial deposits and bedrock.

In 2010, about $60 \%$ of the Classification area was open to the influence of flooding, most of which is part of channel or backwater ecosystem complexes. Landforms that can be influenced by flooding are restricted to a corridor riverward of the flood-control levee systems that isolate about $460 \mathrm{~km}^{2}$ of historical floodplains. Although most reduction in flooding is a result of flood-control levee systems, and in the reaches above Longview, flow-regulation; high dredge material disposal areas and developed floodplain have locally reduced the area that is inundated by most flows.

Naik and Jay (2011) show a mean annual sediment flux that is about $37 \%$ of preregulation flux and a decrease in sand transport to $15 \%$ of historical rates. Decreased sediment supply combined with reduced frequency and magnitude of sediment transport by river floods, isolation of floodplains by levee systems, and channel deepening and confinement for navigation have diminished the ability of flowing water to shape most landscape features within the area of the Classification. 
Isolation and drainage by flood-control systems has directly changed the hydrologic function of two-thirds of surge plains and one-half of floodplain backswamps, resulting in loss of wetland habitat and in the case of surge plains, has caused ground surface subsidence.

New landforms result dominantly from direct anthropogenic actions or in response to anthropogenic perturbations such as dredge material disposal and pile dikes. Landforms directly being created include dredge disposal deposits, deep and permanently flooded channel, and developed floodplains. Habitat improvement activities generally result in new lower flooded surge plains, re-connected tidal channels, new tidal channels, and various other wetlands. Efforts to maintain a navigation channel divert flow away from secondary channels, resulting in shallowing that can evolve into surge plains or wetlands. This concentration of flow, combined with dredging results in a uniformly deep thalweg in the primary channel. Dredge material disposal and other fill placement has resulted in a generally narrower channel. Pile dikes and dredge material disposal have locally resulted in deposition of new wetlands along margins of the primary channel. Near the mouth, dredge disposal provides material that can be re-worked by wind to form dunes or dune-like uplands. 


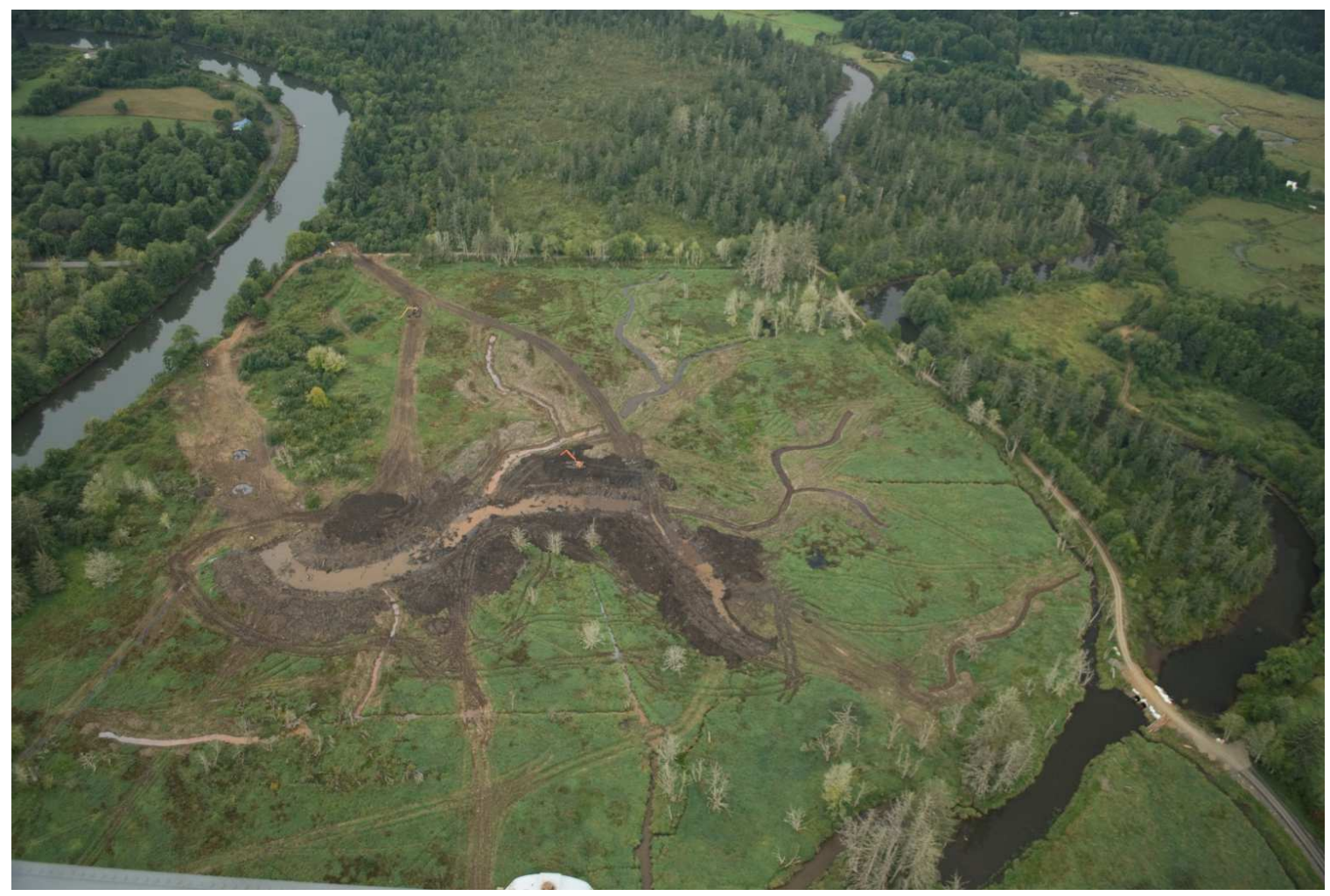

Figure 22. Habitat improvement efforts along the Grays River involve breaching flood-control levees and excavating a tidal channel. These efforts convert an isolated surge plain complex into a lower flooded surge plain and form new tidal channels. Photo C. Cannon, 2013, with aerial support from Lighthawk Aviation.

Although fluvial influence has markedly decreased, tidal range has increased (Jay and others, 2011). Low wetlands along channels could become increasingly tidal in character, perhaps similar to wetlands along Scappoose Bay or near Cunningham Lake that although considered backswamps, have narrow dendritic channels similar to surge plains. Tides high enough to influence most backswamps, although infrequent can occur throughout the year.

Most floodplain landforms upstream of Longview historically had trajectories controlled mostly by flooding during spring freshets. Most floodplain landforms downstream of Longview had trajectories controlled mostly by tides. Inundation as a 
result of either tides or freshets has been variably constrained to a corridor along the primary channel,

Although landforms along the Columbia River are on a trajectory largely controlled by human management, perturbations from coseismic subsidence, volcanism, and atmospheric rivers are likely to influence future landscape evolution. 


\section{Chapter 6: Management implications}

Changed flow regimes and floodplain isolation have limited the ability of flowing water to shape or influence floodplain features and reduced the amount of habitats available for aquatic species. Isolation of surge plains has converted them into a different landform that if re-connected will initially have a different inundation regime than before isolation. Locally, relative subsidence is nearly as much as can be expected during subduction zone earthquakes and is thus likely to exacerbate the effects of coseismic subsidence anticipated to occur during future subduction zone earthquakes.

\section{Chapter 7: Opportunities for Future Work}

Future work to understand the modern landscape along the lower Columbia River could employ hydrodynamic modeling to improve accuracy and precision of the changed inundation regime. Another application of hydrodynamic modeling could be to assess the effects of scour on floodplain backswamps during large freshets. Assessment of potential scour could provide insight into the roles of reduced peak flows and changed floodplain connection in the apparent shoaling of backswamp lakes, and could perhaps guide restoration strategies of those lakes.

Studies investigating subsidence of isolated surge plains could work to separate the different factors that control the amount of relative subsidence. Variables to consider include the effects of autocompaction, compaction by livestock and machinery, oxidation of organic material, and lack of new sediment accretion.

A more comprehensive understanding of sediment accretion rates would aid in understanding geologic processes and could improve the anticipated results of reconnection efforts. Peterson and others (2014) demonstrate that short term accretions 
at a given locality can be much greater than accretion rates averaged over extended periods of time. Knowledge of controls on accretion rates is crucial to predicting the responses of surge-plains to re-connection and their recovery from coseismic subsidence.

\section{References Cited}

Atwater, B.F., Compiler, 1994, Geology of Holocene liquefaction features along the lower Columbia River at Marsh, Brush, Price, Hunting, and Wallace Islands, Oregon and Washington, Open-File Report, U.S. Geological Survey, p. 64.

Atwater, B.F., Tuttle, M.P., Schweig, E.S., Rubin, C.M., Yamaguchi, D.K., and Hemphill-Haley, E., 2004, Earthquake recurrence inferred from paleoseismology: Developments in Quaternary Science, v. 1, p. 331-350.

Baker, D., 2002, Holocene (2-16 ka) Sedimentation in the Columbia River Estuary. Portland, Oregon: Portland State University, MS thesis, 167p.

Baker, D., Peterson, C., Hemphill-Haley, E., and Twichell, D., 2010, Latest Pleistocene and Holocene (2-16 ka) sedimentation in the Columbia River Estuary, Oregon, USA: Marine Geology, v. 273, p. 83-95.

Ballard, R.L., 1964, Distribution of beach sediment near the Columbia River, University of Washington Department of Oceanography Technical Report No. 98: Seattle, Washington, p. 75.

Beeson, M.H., Tolan, T.L., and Madin, I.P., 1989, Geologic map of the Lake Oswego Quadrangle, Clackamas, Multnomah, and Washington Counties, Oregon, State of Oregon Geological Map Series GMS-59, p. 1 sheet. 
Bhagat, S.K., and Orsborn, J.F., 1971, Water quantity and quality studies of Vancouver Lake, Washington: Pullman, Washington, College of Engineering Research Division, Washington State University

Bischoff, J.M., Raymond, R.B., Snyder, K.U., Heigh, L., and Binder, S.K., 2000, Skipanon River Watershed Assessment, E\&S Environmental Chemistry, Inc. and Skipanon River Watershed Council.

Bretz, J H., 1969, The Lake Missoula Floods and the Channeled Scabland: The Journal of Geology, v. 77, p. 505-543.

Brophy, L., Cornu, C., Adamus, P.R., Christy, J.A., Gray, A., Huang, L., MacClellan, M., Doumbia, J., and Tully, R., 2011, New Tools for Tidal Wetland Restoration:

Development of a Reference Conditions Database and a Temperature Sensor Method for Detecting Tidal Inundation in Least-disturbed Tidal Wetlands of Oregon, USA. Amended Final Report, Oregon State University Libraries.

Burgette, R.J., Weldon, R.J., and Schmidt, D.A., 2009, Interseismic uplift rates for western Oregon and along-strike variation in locking on the Cascadia subduction zone: Journal of Geophysical Research: Solid Earth, v. 114, p. B01408.

Burke, J.L., 2010, Historical landcover of the Columbia River estuary: Seattle, School of Aquatic and Fishery Sciences, University of Washington.

Byrnes, M.R., and Li, F., 2001, Regional analysis of sediment transport and dredged material dispersal patterns, Columbia River mouth, Washington/Oregon, and adjacent shores: Mashpee, Massachusetts, Applied Coastal Research and Engineering, Inc. prepared for U.S. Army Corps of Engineers Waterways Experiment Station. 
Cahoon, D., Hensel, P., Spencer, T., Reed, D., McKee, K., and Saintilan, N., 2006, Coastal Wetland Vulnerability to Relative Sea-Level Rise: Wetland Elevation Trends and Process Controls, in Verhoeven, J.A., Beltman, B., Bobbink, R., and Whigham, D., eds., Wetlands and Natural Resource Management, Volume 190: Ecological Studies, Springer Berlin Heidelberg, p. 271-292.

Cahoon, D.R., Reed, D.J., and Day Jr, J.W., 1995, Estimating shallow subsidence in microtidal salt marshes of the southeastern United States: Kaye and Barghoorn revisited: Marine Geology, v. 128, p. 1-9.

Carlson, T.J., Johnson, G.E., Woodley, C.M., Skalski, J.R., and Seaburg, A.G., 2011, Compliance Monitoring of Underwater Blasting for Rock Removal at Warrior Point, Columbia River Channel Improvement Project 2009/2010, Pacific Northwest National Laboratory.

Christy, J.A., and Putera, J., 1993, Lower Columbia River natural area inventory 1992, Report to The Nature Conservancy,Washington Filed Office, Seattle, Oregon Natural Heritage Program.

Clark, S.M., and Snyder, G.R., 1969, Timing and extent of a flow reversal in the lower Columbia River: Limnology and Oceanography, v. 14, p. 960-965.

Columbia River Estuary Study Task Force, 2013, Steamboat Slough restoration environmental assessment, Columbia River Estuary Study Task Force for U.S. Army Corps of Engineers.

Cooper, W.S., 1958, Coastal sand dunes of Oregon and Washington: Geological Society of America Memoirs, v. 72, p. 1-162. 
Cornu, C.E., and Sadro, S., 2002, Physical and Functional Responses to Experimental Marsh Surface Elevation Manipulation in Coos Bay's South Slough: Restoration Ecology, v. 10, p. 474-486.

Crandell, D.R., 1987, Deposits of pre-1980 pyroclastic flows and lahars from Mount St. Helens Volcano, Washington, U.S. Geological Survey Professional Paper 1444, p. 91. David C. Smith and Associates, I., 2011, Columbia River LiDAR project (final summary report).

Eriksson, A., 2002, Stratigraphy, structure, and natural gas potential of tertiary sedimentary and volcanic units, Clatskanie 7.5 minute quadrangle, Northwest Oregon: Corvallis, Oregon State University.

Evarts, R., 2004, Geologic map of the Ridgefield quadrangle, Clark and Cowlitz Counties, Washington: US Geological Survey Scientific Investigations Map, Volume 2844.

Evarts, R.C., 2002, Geologic map of the Deer Island Quadrangle, Columbia County, Oregon and Cowlitz County, Washington, Miscellaneous Field Studies Map 2392, U.S. Geological Survey, p. 45 p. and 1 sheet.

—, 2004, Geologic Map of the Saint Helens Quadrangle, Columbia County, Oregon, and Clark and Cowlitz Counties, Washington, U.S. Geological Survey Scientific Investigations Map 2834, p. map, 34 by 44 inches; 24 p. pamphlet; data files. —, 2004, Geologic Map of the Woodland Quadrangle, Clark and Cowlitz Counties, Washington, Clark and Cowlitz Counties, Washington: U.S. Geological Survey Scientific Investigations Map 2827. 
Evarts, R.C., O'Connor, J.E., and Tolan, T.L., 2013, Geologic map of the Washougal quadrangle, Clark County, Washington, and Multnomah County, Oregon, U.S.

Geological Survey Scientific Investigations Map 3257: Reston, VA.

Evarts, R.C., O'Connor, J.E., Wells, R.E., and Madin, I.P., 2009, The Portland Basin: A (big) river runs through it: GSA Today, v. 19, p. 4-10.

Evarts, R.C., and O'Connor, J.E., 2008, Geologic Map of the Camas Quadrangle, Clark County, Washington, and Multnomah County, Oregon, U.S. Geological Survey Scientific Investigations Map 3017, p. Map Sheet: 43 x 36 inches; Pamphlet; Data Files.

Fagherazzi, S., 2013, The ephemeral life of a salt marsh: Geology, v. 41, p. 943-944.

Fenneman, N.M., and Johnson, D.W., 1946, Physiographic divisions of the conterminous U. S.: Reston, VA, U.S. Geological Survey.

Frenkel, R.E., and Morlan, J.C., 1991, Can we restore our salt marshes? Lessons from the Salmon River, Oregon: Northwest Environmental Journal, v. 7, p. 119-135.

Friedrichs, C.T., and Perry, J.E., 2001, Tidal Salt Marsh Morphodynamics: A Synthesis: Journal of Coastal Research, p. 7-37.

Galster, R.W., 2005, Human influence on the Columbia River littoral cell: Reviews in Engineering Geology, v. 16, p. 67-77.

Gates, E.B., 1994, The Holocene sedimentary framework of the lower Columbia River basin: Portland, Oregon, Portland State University.

Gelfenbaum, G., Sherwood, C.R., Peterson, C.D., Kaminsky, G.M., Buijsman, M., Twichell, D.C., Ruggiero, P., Gibbs, A.E., and Reed, C., 1999, The Columbia River littoral cell: a sediment budget overview, $4^{\text {th }}$ International Conference on Coastal 
Engineering and Coastal Sediment Processes: Coastal Sediments '99: Long Island, NY, American Society of Civil Engineers, p. 1660-1675.

Gunnell, J.R., Rodriguez, A.B., and McKee, B.A., 2013, How a marsh is built from the bottom up: Geology, v. 41, p. 859-862.

Handbury, T.H., 1891, Improvements, Columbia and Lower Willamette Rivers below Portland, Oregon, in U.S. Army Corps of Engineers, ed.: Annual Report of the Chief of Engineers United States Army, to the Secretary of War for the Year 1891: Washington, Government Printing Office, p. 3364-3365.

Haushild, W.L., Perkins, R.W., Stevens, H.H., Dempster, G.R., Jr., and Glenn, J.L., 1966, Radionuclide Transport in the Pasco to Vancouver, Washington Reach of the Columbia River, July 1962 to September 1963: Progress Report, U.S. Geological Survey Openfile Report, p. 188.

Hickey, B.M., 1998, Coastal oceanography of Western North America from the tip of Baja California to Vancouver Island, in Brink, K.H., and Robinson, A.R., eds., The Sea, Volume 11: New York, Wiley and Sons, Inc.

Hood, W., 2007, Landscape allometry and prediction in estuarine ecology: Linking landform scaling to ecological patterns and processes: Estuaries and Coasts, v. 30, p. $895-900$.

Hubbell, D.W., Laenen, J.M., and McKenzie, S.W., 1983, Characteristics of Columbia River sediment following the eruption of Mount St. Helens on May 18, 1980, U.S. Geological Survey Circular 850-J, p. 21. 
Jay, D., Leffler, K., Diefenderfer, H., and Borde, A., 2014, Tidal-Fluvial and Estuarine Processes in the Lower Columbia River: I. Along-Channel Water Level Variations, Pacific Ocean to Bonneville Dam: Estuaries and Coasts, p. 1-19.

Jay, D.A., Leffler, K., and Degens, S., 2011, Long-Term Evolution of Columbia River Tides: Journal of waterway, port, coastal, and ocean engineering, v. 137, p. 182-191. Jay, D.A., 1984, Circulatory processes in the Columbia River estuary: Astoria, Columbia River Estuary Data Development Program, p. 169.

Jay, D.A., Giese, B.S., and Sherwood, C.R., 1990, Energetics and sedimentary processes in the Columbia River Estuary: Progress In Oceanography, v. 25, p. 157-174.

Kaminsky, G.M., Ruggiero, P., Buijsman, M.C., McCandless, D., and Gelfenbaum, G., 2010, Historical evolution of the Columbia River littoral cell: Marine Geology, v. 273, p. $96-126$.

Kaye, C.A., and Barghoorn, E.S., 1964, Late Quaternary Sea-Level Change and Crustal Rise at Boston, Massachusetts, with Notes on the Autocompaction of Peat: Geological Society of America Bulletin, v. 75, p. 63-80.

Klingeman, P.C., 1987, Environmental assessment for Sturgeon Lake restoration project: Corvallis, Oregon, Water Resources Research Institute, p. 18.

Knapp, P.A., and Hadley, K.S., 2011, Lewis and Clarks' Tempest: The 'perfect storm' of November 1805, Oregon, USA: The Holocene, v. 21, p. 693-697.

Komar, P.D., Allan, J.C., and Ruggiero, P., 2011, Sea Level Variations along the U.S.

Pacific Northwest Coast: Tectonic and Climate Controls: Journal of Coastal Research, p. $808-823$. 
Kukulka, T., and Jay, D.A., 2003, Impacts of Columbia River discharge on salmonid habitat: 1. A nonstationary fluvial tide model: Journal of Geophysical Research: Oceans, v. 108, p. 3293.

Kunze, L.M., 1994, Preliminary classification of native, low elevation, freshwater wetland vegetation in western Washington: Olympia, Washington, Washington State Department of Natural Resources, Natural Heritage Program.

Latrubesse, E.M., and Franzinelli, E., 2002, The Holocene alluvial plain of the middle Amazon River, Brazil: Geomorphology, v. 44, p. 241-257.

Leonard, L.J., Currie, C.A., Mazzotti, S., and Hyndman, R.D., 2010, Rupture area and displacement of past Cascadia great earthquakes from coastal coseismic subsidence: Geological Society of America Bulletin, v. 122, p. 2079-2096.

Lower Columbia River Estuary Partnership, 2011, High Resolution Land Cover, Lower Columbia River Estuary. OR \& WA, United States, 2007-2010.

Ma, L., Madin, I.P., Olson, K.V., and Watzig, R.J., 2009, Oregon Geologic Data Compilation version 5, Oregon Department of Geology and Mineral Industries.

Makaske, B., 2001, Anastomosing rivers: a review of their classification, origin and sedimentary products: Earth-Science Reviews, v. 53, p. 149-196.

Mantua, N.J., Hare, S.R., Zhang, Y., Wallace, J.M., and Francis, R.C., 1997, A Pacific Interdecadal Climate Oscillation with Impacts on Salmon Production: Bulletin of the American Meteorological Society, v. 78, p. 1069-1079.

Mass, C., and Dotson, B., 2010, Major Extratropical Cyclones of the Northwest United States: Historical Review, Climatology, and Synoptic Environment: Monthly Weather Review, v. 138, p. 2499-2527. 
McCutcheon, M.S., 2003, Stratigraphy and sedimentology of the Middle Eocene Cowlitz Formation and adjacent sedimentary and volcanic units in the Longview-Kelso area, southwest Washington: Corvallis, Oregon State University.

Meybeck, M., 2003, Global analysis of river systems: from Earth system controls to Anthropocene syndromes: Philosophical Transactions of the Royal Society of London.

Series B: Biological Sciences, v. 358, p. 1935-1955.

Milliman, J.D., and Farnsworth, K.L., 2011, River Discharge to the Coastal Ocean : A

Global Synthesis: Cambridge, Cambridge University Press.

Mitchell, D.L., 1981, Salt marsh reestablishment following dike breaching in the Salmon River estuary, Oregon: Corvallis, Oregon State University.

Murphy, T.M., 1981, The geology of the Nicolai Mountain-Gnat Creek area, Clatsop County, northwestern Oregon: Corvallis, Oregon, Oregon State University.

Naik, P.K., and Jay, D.A., 2005, Estimation of Columbia River virgin flow: 1879 to 1928: Hydrological Processes, v. 19, p. 1807-1824.

—, 2011, Distinguishing human and climate influences on the Columbia River: Changes in mean flow and sediment transport: Journal of Hydrology, v. 404, p. 259-277.

Neiman, P.J., Schick, L.J., Ralph, F.M., Hughes, M., and Wick, G.A., 2011, Flooding in Western Washington: The Connection to Atmospheric Rivers*: Journal of Hydrometeorology, v. 12, p. 1337-1358.

Neuendorf, K.K.E., Mehl, J.P., Jr, and Jackson, J.A., 2005, Glossary of Geology: Alexandria, Virginia, American Geological Institute.

Niem, A., and Niem, W., 1985, Geologic map of the Astoria Basin Clatsop and northernmost Tillamook Counties, northwest Oregon, Oregon Department of Geology 
and Mineral Industries Oil and Gas Investigations, Volume 14, Oregon Department of Geology and Mineral Industries Oil and Gas Investigations 14

O'Connor, J.E., 2004, The Evolving Landscape of the Columbia River Gorge: Lewis and Clark and Cataclysms on the Columbia: Oregon Historical Quarterly, v. 105, p. 390421.

O'Connor, J.E., and Burns, S.F., 2009, Cataclysms and controversy—Aspects of the geomorphology of the Columbia River Gorge: Geological Society of America Field Guides, v. 15 , p. $237-251$.

Petersen, J.H., Reisenbichler, R., Gelfenbaum, G.R., Peterson, C., Baker, D., Leavitt, P., Simenstad, S., and Prahl, F., 2003, Historical changes in the Columbia River estuary based on sediment cores: feasibility studies, U.S. Geological Survey Administrative Report: Cook, Washington, U.S. Geological Survey, p. 73.

Peterson, C.D., Darienzo, M.E., Burns, S.F., and Burris, W., 1993, Field trip guide to Cascadia paleoseismic evidence along the northern Oregon coast: Evidence of subduction zone seismicity in the central Cascadia margin: Oregon Geology, v. 55, p. $99-114$.

Peterson, C.D., Doyle, D.L., and Barnett, E.T., 2000, Coastal flooding and beach retreat from coseismic subsidence in the central Cascadia margin, USA: Environmental \& Engineering Geoscience, v. 6, p. 255-269.

Peterson, C.D., Minor, R., Gates, E.B., Vanderburgh, S., and Carlisle, K., 2012, Correlation of Tephra Marker Beds in Latest Pleistocene and Holocene Fill of the Submerged Lower Columbia River Valley, Washington and Oregon, USA: Journal of Coastal Research. 
Peterson, C.D., Minor, R., Peterson, G.L., and Gates, E.B., 2011, Pre-and post-Missoula flood geomorphology of the Pre-Holocene ancestral Columbia River Valley in the Portland forearc basin, Oregon and Washington, USA: Geomorphology, v. 129, p. 276293.

Peterson, C.D., Vanderburgh, S., and Roberts, M.C., 2014, Late Holocene

Geomorphology of the Columbia River Estuary, Oregon and Washington, USA: Journal of Geography and Geology, v. 6.

Phillips, W.M., 1987, Geologic map of the Mount St. Helens quadrangle, Washington and Oregon, Open-File Report 87-4, Washington Division of Geology and Earth Resources, p. 48 p., 1 pl.

—, 1987, Geologic map of the Vancouver quadrangle, Washington and Oregon, Openfile Report 87-10, Washington Division of Geology and Earth Resources, p. 27 p., 1 pl. Pierson, T.C., Pringle, P.T., and Cameron, K.A., 2011, Magnitude and timing of downstream channel aggradation and degradation in response to a dome-building eruption at Mount Hood, Oregon: Geological Society of America Bulletin, v. 123, p. 320.

Popowski, T.A., 1996, Geology, structure, and tectonic history of the Tualatin Basin, northwestern Oregon: Corvallis, Oregon, Oregon State University, M.S. Thesis.

Rantz, S.E., and Riggs, H.C., 1949, Floods of May-June 1948 in Columbia River basin, with a section on Magnitude and frequency of floods, Water Supply Paper 1080, U.S. Government Printing Office, p. 476.

Rapp, B., 2005, The Holocene stratigraphy of the Sandy River delta: Portland, Oregon, Portland State University, M.S. Thesis. 
Rapp, B.K., Craney, E., and Burns, S.F., 2002, Geomorphic and pedologic origins of the Rooster Rock dune, Oregon, Cordilleran Section - 98th Annual Meeting (May 13-15, 2002), Geological Society of America.

Reckendorf, F., Peterson, C., and Percy, D., 2001, The dune ridges of Clatsop County, Oregon Oregon Department of Geology and Mineral Industries Open-file Report O-0107.

Redfield, A.C., 1972, Development of a New England Salt Marsh: Ecological Monographs, v. 42, p. 201-237.

Reed, D., Spencer, T., Murray, A., French, J., and Leonard, L., 1999, Marsh surface sediment deposition and the role of tidal creeks: Implications for created and managed coastal marshes: Journal of Coastal Conservation, v. 5, p. 81-90.

Rojstaczer, S., and Deverel, S.J., 1993, Time dependence in atmospheric carbon inputs from drainage of organic soils: Geophysical Research Letters, v. 20, p. 1383-1386.

Ropelewski, C.F., and Halpert, M.S., 1986, North American Precipitation and Temperature Patterns Associated with the El Niño/Southern Oscillation (ENSO): Monthly Weather Review, v. 114, p. 2352-2362.

Rowland, J.C., Dietrich, W.E., Day, G., and Parker, G., 2009, Formation and maintenance of single-thread tie channels entering floodplain lakes: Observations from three diverse river systems: Journal of Geophysical Research: Earth Surface, v. 114, p. $1-19$.

Rowson, D.R., and Colucci, S.J., 1992, Synoptic climatology of thermal low-pressure systems over south-western north America: International Journal of Climatology, v. 12, p. 529-545. 
Ruggiero, P., Kaminsky, G.M., Gelfenbaum, G., and Voigt, B., 2005, Seasonal to Interannual Morphodynamics along a High-Energy Dissipative Littoral Cell: Journal of Coastal Research, p. 553-578.

Ruzek, C.V., and Carpenter, E.J., 1919, Multnomah County sheet, U.S. Department of Agriculture Bureau of Soils Soil Map.

—, 1922, Soil Survey of Multnomah County, Oregon, U.S. Department of Agriculture, Bureau of Soils, p. 98.

Scott, K.M., 1988, Origins, behavior, and sedimentology of lahars and lahar-runout flows in the Toutle-Cowlitz River system, U.S. Geological Survey Professional Paper 1447A, p. 74.

$\ldots$, 1989, Magnitude and frequency of lahars and lahar-runout flows in the ToutleCowlitz River system, U.S. Geological Survey Professional Paper 1447-B, p. 25.

Shalowitz, A.L., 1964, Shore and Sea Boundaries Volume Two, Interpretation and use of Coast and Geodetic Survey data, US Dept. of Commerce, Coast and Geodetic Survey, U.S. Government Printing Office.

Sharp, J., and Mass, C.F., 2004, Columbia Gorge Gap Winds: Their Climatological Influence and Synoptic Evolution: Weather and Forecasting, v. 19, p. 970-992.

Shaw, S., Hinkle, J., and Seward, J., 2008, Geotechnical Assessment of the December 2007 Debris Flow Complex in Eilertsen Creek, Woodson, Oregon, Oregon Department of Forestry.

Sherwood, C.R., and Creager, J.S., 1990, Sedimentary geology of the Columbia River Estuary: Progress in Oceanography, v. 25, p. 15-79. 
Simenstad, C.A., Burke, J.L., O'Connor, J.E., Cannon, C., Heatwole, D.W., Ramirez, M.F., Waite, I.R., Counihan, T.D., and Jones, K.L., 2011, Columbia River Estuary Ecosystem Classification-Concept and application, Open-File Report, U.S.

Geological Survey, p. 54.

Smith, N.D., Cross, T.A., Dufficy, J.P., and Clough, S.R., 1989, Anatomy of an avulsion: Sedimentology, v. 36, p. 1-23.

Smith, N.D., and Perez-Arlucea, M., 1994, Fine-grained splay deposition in the avulsion belt of the lower Saskatchewan River, Canada: Journal of Sedimentary Research, v. 64, p. 159-168.

Smythe, R.T., 1986, Soil Survey of Columbia County, Oregon, U.S. Department of Agriculture, Soil Conservation Service.

Stephens, J.C., Allen, L.H., and Chen, E., 1984, Organic soil subsidence: Reviews in Engineering Geology, v. 6, p. 107-122.

Stolz, A., Martin, C., and Wong, C., 2005, Vertical control in a tidally influenced complex river system with a fixed low water datum, U.S Hydrographic Conference 2005

Takada, K., and Atwater, B.F., 2004, Evidence for Liquefaction Identified in Peeled Slices of Holocene Deposits along the Lower Columbia River, Washington: Bulletin of the Seismological Society of America, v. 94, p. 550-575.

Tolkova, E., 2013, Tide-Tsunami Interaction in Columbia River, as Implied by Historical Data and Numerical Simulations: Pure and Applied Geophysics, v. 170, p. 1115-1126. 
Tornqvist, T.E., Wallace, D.J., Storms, J.E.A., Wallinga, J., van Dam, R.L., Blaauw, M., Derksen, M.S., Klerks, C.J.W., Meijneken, C., and Snijders, E.M.A., 2008, Mississippi Delta subsidence primarily caused by compaction of Holocene strata: Nature Geosciences, v. 1, p. 173-176.

U.S. Army Corps of Engineers, 1968 (revised), Columbia River and tributaries

Washington and Oregon below Bonneville Dam: Portland, Oregon, U.S. Army

Engineer District, p. Flood profiles, drawing CL-03-116.

—, 1978, Columbia River Datum elevations.

—, 2010, Columbia River Terrain Model - Reach01, Digital elevation data for Columbia River.

U.S. Coast Guard, Navigability Determinations for Thirteenth Coast Guard District U.S. Environmental Protection Agency, 1978, Final Environmental Impact Statemen for Vancouver Lake reclamation study,Port of Vancouver, Clark County, Washington, EPA 910/9-77-046: Seattle, Washington, U. S. Environmental Protection Agency Region 10.

—, 2000, Level III Ecoregions of the Continental United States (revision of Omernik, 1987), Map M-1: Corvallis, OR, U.S. Environmental Protection Agency - National Health and Environmental Effects Research Laboratory.

Vogel, M.S., 2005, Quaternary geology of the lower Lewis River valley, WashingtonInfluence of volcanogenic sedimentation following Mount St. Helens Eruptions:

Pullman, Washington, Washington State University. 
Walsh, T.J., 1987, Geologic map of the Astoria and Ilwaco quadrangles, Washington and Oregon, Open File Report 87-2, Washington Division of Geology and Earth Resources, p. 28 p., 1 pl.

Warner, M.D., Mass, C.F., and Salathé, E.P., 2012, Wintertime Extreme Precipitation Events along the Pacific Northwest Coast: Climatology and Synoptic Evolution:

Monthly Weather Review, v. 140, p. 2021-2043.

Washington Division of Geology and Earth Resources, 2008, 1:100,000-Scale Digital Geology of Washington State, in Harris, C.F.T., and Schuster, J.E., eds., Open File Report 2005-3: Olympia, Washington.

Wells, E.L., 1947, Notes on the winter of 1861-1862 in the Pacific Northwest: Northwest Science, v. XXI, p. 76-82.

Wells, R.E., 1981, Geologic map of the eastern Willapa Hills, Cowlitz, Lewis, Pacific, and Wahkiakum counties, Washington, U.S. Geological Survey Open-File Report 81674, p. 1 map.

—, 1989, Geologic map of the Cape Disappointment-Naselle River area, Pacific and Wahkiakum counties, Washington, U.S. Geological Survey Miscellaneous Investigations Series Map I-1832.

Wells, R.E., Niem, A.R., Evarts, R.C., and Hagstrum, J.T., 2009, The Columbia River Basalt Group-From the gorge to the sea: Field Guides, v. 15, p. 737-774.

Whetten, J.T., Kelley, J.C., and Hanson, L.G., 1969, Characteristics of Columbia River sediment and sediment transport: Journal of Sedimentary Petrology, v. 39, p. 11491166. 
Willingham, W.F., 1983, Army Engineers and the Development of Oregon: A History of the Portland District U.S. Army Corps of Engineers U.S. Government Printing Office, $258 \mathrm{p}$.

Wohl, E., 2005, Disconnected rivers: Human impacts to rivers in the United States: Reviews in Engineering Geology, v. 16, p. 19-34.

Wolfe, E.W., and McKee, E.H., 1968, Geology of the Grays River Quadrangle, Wahkiakum and Pacific Counties, Washington, Geologic Map GM-4, State of Washington, Department of Natural Resources, Division of Mines and Geology. Woodruff, J.D., Martini, A.P., Elzidani, E.Z.H., Naughton, T.J., Kekacs, D.J., and MacDonald, D.G., 2013, Off-river waterbodies on tidal rivers: Human impact on rates of infilling and the accumulation of pollutants: Geomorphology, v. 184, p. 38-50.

Yeh, H., Tolkova, E., Jay, D., Talke, S., and Fritz, H., 2012, Tsunami Hydrodynamics in the Columbia River: Journal of Disaster Research, v. 7, p. 604-608.

Zervas, C., Gill, S., and Sweet, W., 2013, Estimating Vertical Land Motion from LongTerm Tide Gauge Records, National Oceanic and Atmospheric Administration Technical Report NOS CO-OPS 065 Silver Spring, Maryland p. 16. 


\section{Appendices}

\section{Appendix A. Area and Distribution of Ecosystem Complexes}

Table A1. Area of ecosystem complexes

\begin{tabular}{|c|c|c|c|}
\hline Complex & Brief description & $\begin{array}{l}\text { Percent of } \\
\text { Classification }\end{array}$ & $\begin{array}{l}\text { Area } \\
\left(\mathrm{km}^{2}\right)\end{array}$ \\
\hline \multicolumn{4}{|c|}{ Channel and Backwater Complexes } \\
\hline Primary channel & Primary channel of the Columbia River & 32.8 & 508.4 \\
\hline Secondary channel & $\begin{array}{l}\text { Channel that is connected to the } \\
\text { Columbia at both ends at least } \\
\text { seasonally }\end{array}$ & 4.4 & 68.2 \\
\hline $\begin{array}{l}\text { Tributary secondary } \\
\text { channel }\end{array}$ & $\begin{array}{l}\text { Channel beginning in a tributary and } \\
\text { connected to a larger channel at both } \\
\text { ends at least seasonally }\end{array}$ & 0.5 & 8.3 \\
\hline Tributary channel & $\begin{array}{l}\text { Larger river tributaries to the Columbia } \\
\text { River }\end{array}$ & 3.4 & 53.0 \\
\hline Backwater embayment & $\begin{array}{l}\text { Waterbodies connected to tributary or } \\
\text { primary channel at their lower end }\end{array}$ & 0.4 & 6.4 \\
\hline \multicolumn{4}{|c|}{ Surge Plain complexes } \\
\hline Surge plain & $\begin{array}{l}\text { Low relief areas affected by tidal } \\
\text { processes that support vegetation }\end{array}$ & 5.3 & 81.9 \\
\hline Isolated surge plain & $\begin{array}{l}\text { Low relief formerly affected by tidal } \\
\text { processes, but disconnected from tidal } \\
\text { influence }\end{array}$ & 10.6 & 164.4 \\
\hline \multicolumn{4}{|c|}{ Floodplain complexes } \\
\hline Floodplain backswamp & $\begin{array}{l}\text { Low floodplain areas behind the natural } \\
\text { levee of a river }\end{array}$ & 7.9 & 122.5 \\
\hline $\begin{array}{l}\text { Floodplain ridge and } \\
\text { swale }\end{array}$ & Areas of alternating ridges and swales & 5.5 & 85.8 \\
\hline Floodplain & $\begin{array}{l}\text { Generic floodplain, areas that are not } \\
\text { further classified }\end{array}$ & 6.3 & 98.2 \\
\hline Crevasse splay & Delta in floodplain lake or wetland & 1.9 & 29.8 \\
\hline \multicolumn{4}{|c|}{ Tributary complexes } \\
\hline Tributary fan & Alluvial fans from tributaries & 1.3 & 20.0 \\
\hline Tributary floodplain & $\begin{array}{l}\text { Floodplains of tributary valleys where } \\
\text { not mapped in detail and floodplains of } \\
\text { minor tributaries where there are } \\
\text { features of the minor tributary within the } \\
\text { floodplain of the Columbia River or its } \\
\text { tributaries }\end{array}$ & 2.8 & 42.8 \\
\hline Volcanogenic delta & $\begin{array}{l}\text { Accumulation of volcanogenic debris at } \\
\text { mouths of rivers whose drainage } \\
\text { includes slopes of active volcanoes }\end{array}$ & 3.8 & 59.0 \\
\hline
\end{tabular}




\begin{tabular}{|c|c|c|c|}
\hline \multicolumn{4}{|c|}{ Anthropogenic Complexes } \\
\hline Developed & Completely obscured by development & 5.3 & 82.1 \\
\hline Dredge disposal areas & Dredge material disposal sites & 2.0 & 31.0 \\
\hline \multicolumn{4}{|c|}{ Non-fluvial and Relict Complexes } \\
\hline Bedrock & Bedrock above surface of floodplain & 0.5 & 7.5 \\
\hline Dune deposit & Accumulation of wind-blown sediment & 3.1 & 48.6 \\
\hline Outburst flood deposits & $\begin{array}{l}\text { Material deposited from the breaching of } \\
\text { a large landslide dam and associated } \\
\text { rapid draining of its impounded lake }\end{array}$ & 0.3 & 3.9 \\
\hline Landslide & $\begin{array}{l}\text { Mass wasting deposits within the } \\
\text { Holocene floodplain }\end{array}$ & 0.4 & 6.5 \\
\hline Terrace & $\begin{array}{l}\text { Alluvial deposit that owes to a pre- } \\
\text { historic flow regime or base level }\end{array}$ & 1.3 & 20.6 \\
\hline Unknown & $\begin{array}{l}\text { Insufficient information for } \\
\text { classification }\end{array}$ & 0.1 & 0.8 \\
\hline
\end{tabular}

Table A2. Area of ecosystem complexes by hydrogeomorphic reach. All values are in square kilometers.

\begin{tabular}{|c|c|c|c|c|c|c|c|c|c|}
\hline Complex & A & B & C & D & E & $F$ & G & H & $\begin{array}{l}\text { Total } \\
\text { area }\end{array}$ \\
\hline \multicolumn{10}{|c|}{ Channel and Backwater Complexes } \\
\hline $\begin{array}{l}\text { Primary } \\
\text { channel }\end{array}$ & 126.3 & 211.3 & 40.6 & 13.8 & 19.3 & 25.5 & 41.3 & 30.3 & 508.4 \\
\hline $\begin{array}{l}\text { Secondary } \\
\text { channel }\end{array}$ & 0.0 & 24.7 & 20.8 & 2.4 & 2.6 & 0.8 & 13.8 & 3.1 & 68.2 \\
\hline $\begin{array}{l}\text { Tributary } \\
\text { secondary } \\
\text { channel }\end{array}$ & 0.0 & 0.0 & 0.0 & 0.0 & 0.0 & 8.3 & 0.0 & 0.0 & 8.3 \\
\hline $\begin{array}{l}\text { Tributary } \\
\text { channel }\end{array}$ & 19.6 & 5.2 & 1.2 & 5.0 & 2.7 & 18.5 & 0.8 & 0.0 & 53.0 \\
\hline $\begin{array}{l}\text { Backwater } \\
\text { embayment }\end{array}$ & 0.1 & 0.3 & 1.6 & 0.7 & 0.3 & 2.9 & 0.5 & 0.0 & 6.4 \\
\hline \multicolumn{10}{|c|}{ Surge Plain complexes } \\
\hline Surge plain & 8.5 & 55.5 & 17.8 & 0.0 & 0.0 & 0.0 & 0.0 & 0.0 & 81.8 \\
\hline $\begin{array}{l}\text { Isolated surge } \\
\text { plain }\end{array}$ & 49.0 & 40.0 & 69.6 & 5.8 & 0.0 & 0.0 & 0.0 & 0.0 & 164.4 \\
\hline \multicolumn{10}{|c|}{ Floodplain complexes } \\
\hline $\begin{array}{l}\text { Floodplain } \\
\text { backswamp }\end{array}$ & 0.0 & 1.1 & 7.1 & 3.4 & 3.9 & 88.4 & 18.0 & 0.5 & 122.5 \\
\hline $\begin{array}{l}\text { Floodplain } \\
\text { ridge and } \\
\text { swale }\end{array}$ & 0.0 & 1.6 & 8.2 & 3.6 & 15.9 & 40.0 & 15.4 & 1.1 & 85.8 \\
\hline Floodplain & 2.5 & 8.2 & 7.6 & 11.9 & 9.3 & 26.8 & 26.4 & 5.4 & 98.2 \\
\hline Crevasse splay & 0.0 & 0.0 & 2.7 & 0.7 & 0.6 & 23.8 & 1.9 & 0.1 & 29.8 \\
\hline
\end{tabular}




\begin{tabular}{|c|c|c|c|c|c|c|c|c|c|}
\hline \multicolumn{10}{|c|}{ Tributary complexes } \\
\hline Tributary fan & 0.7 & 2.5 & 2.7 & 1.0 & 0.9 & 3.0 & 1.0 & 8.3 & 20.0 \\
\hline $\begin{array}{l}\text { Tributary } \\
\text { floodplain }\end{array}$ & 3.1 & 9.4 & 0.4 & 3.1 & 15.4 & 6.2 & 4.2 & 0.9 & 42.8 \\
\hline $\begin{array}{l}\text { Volcanogenic } \\
\text { delta }\end{array}$ & 0.0 & 0.0 & 0.0 & 16.2 & 31.8 & 0.0 & 11.0 & 0.0 & 59.0 \\
\hline \multicolumn{10}{|c|}{ Anthropogenic Complexes } \\
\hline Developed & 5.2 & 1.5 & 3.2 & 17.2 & 1.9 & 29.8 & 21.2 & 2.1 & 82.1 \\
\hline $\begin{array}{l}\text { Dredge } \\
\text { disposal areas }\end{array}$ & 0.9 & 5.5 & 5.8 & 9.0 & 4.1 & 3.4 & 2.2 & 0.0 & 31.0 \\
\hline \multicolumn{10}{|c|}{ Non-fluvial and Relict Complexes } \\
\hline Bedrock & 0.4 & 0.4 & 1.3 & 2.2 & 0.0 & 2.4 & 0.7 & 0.1 & 7.5 \\
\hline Dune & 35.6 & 0.0 & 0.0 & 0.0 & 0.0 & 12.1 & 0.1 & 0.8 & 48.6 \\
\hline $\begin{array}{l}\text { Outburst flood } \\
\text { deposits }\end{array}$ & 0.0 & 0.0 & 0.0 & 0.0 & 0.0 & 0.0 & 0.0 & 3.9 & 3.9 \\
\hline Landslide & 0.0 & 0.4 & 1.3 & 0.0 & 0.2 & 0.1 & 0.0 & 4.5 & 6.5 \\
\hline Terrace & 0.6 & 0.2 & 0.3 & 0.0 & 0.5 & 10.8 & 8.2 & 0.0 & 20.6 \\
\hline Unknown & 0.1 & 0.0 & 0.0 & 0.0 & 0.2 & 0.1 & 0.0 & 0.2 & 0.8 \\
\hline
\end{tabular}

\section{Appendix B. Areas of Accretion and Erosion since earliest U.S. Coast and Geodetic Survey}

\section{Maps}

Table B1. Areas of accreted and eroded land since earliest U.S. Coast and Geodetic Survey maps.

\begin{tabular}{lcc}
\hline Hydrogeomorphic Reach & Accretion $\left(\mathbf{k m}^{2}\right)$ & Erosion $\left(\mathbf{k m}^{2}\right)$ \\
\hline A & 4.8 & 2.4 \\
B & 11.7 & 13.0 \\
C & 12.5 & 3.2 \\
D & 4.5 & 0.9 \\
E & 5.1 & 1.4 \\
F & 3.9 & 1.8 \\
G & 6.0 & 4.2 \\
H* & 0.3 & 0.0 \\
\hline
\end{tabular}

*Only the downstream-most end of Reach $\mathrm{H}$ is included in this analysis 
Table B2. Area of geomorphic catenae with more than $1 \mathrm{~km}^{2}$ of accreted land since earliest U.S. Coast and Geodetic Survey maps.

\begin{tabular}{llc}
\hline \multicolumn{1}{c}{ Geomorphic Catena } & Area $\left(\mathbf{k m}^{2)}\right.$ & $\begin{array}{c}\text { Percent of Total } \\
\text { Deposition }\end{array}$ \\
\hline Dredge disposal area & 16.8 & 34.5 \\
Lower flooded & 7.1 & 14.5 \\
Wetland & 4.3 & 8.9 \\
Natural levee & 4.1 & 8.5 \\
Developed floodplain & 3.1 & 6.4 \\
Filled areas & 2.9 & 5.9 \\
Floodplain & 2.5 & 5.1 \\
Upper flooded & 2.2 & 4.5 \\
Undifferentiated flooded & 2.2 & 4.5 \\
Dune & 2.2 & 4.4 \\
\hline
\end{tabular}

Table B3. Area of ecosystem complexes with more than $1 \mathrm{~km} 2$ of accreted land since earliest U.S. Coast and Geodetic Survey maps.

\begin{tabular}{lcc}
\hline \multicolumn{1}{c}{ Ecosystem Complex } & Area $\mathrm{km}^{2}$ & $\begin{array}{c}\text { Percent of Total } \\
\text { Deposition }\end{array}$ \\
\hline Dredge disposal area & 16.8 & 34.5 \\
Surge plain & 12.1 & 24.9 \\
Floodplain & 6.7 & 13.9 \\
Developed & 5.4 & 11.1 \\
Floodplain ridge and swale & 4.8 & 10.0 \\
Dune & 2.2 & 4.4 \\
\hline
\end{tabular}

Table B4. Area of historical (T-sheet) landcover classes from Burke (2010) with more than $0.5 \mathrm{~km} 2$ of erosion since earliest U.S. Coast and Geodetic Survey maps.

\begin{tabular}{lcc}
\hline \multicolumn{1}{c}{ Land Cover } & Area $\mathbf{k m}^{2}$ & Percent of Total Erosion \\
\hline submerged marsh & 6.0 & 22.3 \\
Woodland & 5.7 & 21.0 \\
wooded marsh & 5.4 & 20.2 \\
Marsh & 3.9 & 14.5 \\
Sand & 2.5 & 9.2 \\
scrub-shrub marsh & 0.6 & 2.1 \\
Grass & 0.6 & 2.1 \\
Shrubs & 0.5 & 2.0 \\
Unclassified & 0.5 & 2.0 \\
\hline
\end{tabular}

